\title{
Donald Trump: A Critical Theory-Perspective on Authoritarian Capitalism
}

\author{
Christian Fuchs
}

University of Westminster, London, UK, christian.fuchs@uti.at, @fuchschristian

\begin{abstract}
This paper analyses economic power, state power and ideological power in the age of Donald Trump with the help of critical theory. It applies the critical theory approaches of thinkers such as Franz Neumann, Theodor W. Adorno and Erich Fromm. It analyses changes of US capitalism that have together with political anxiety and demagoguery brought about the rise of Donald Trump. This article draws attention to the importance of state theory for understanding Trump and the changes of politics that his rule may bring about. It is in this context important to see the complexity of the state, including the dynamic relationship between the state and the economy, the state and citizens, intra-state relations, inter-state relations, semiotic representations of and by the state, and ideology. Trumpism and its potential impacts are theorised along these dimensions. The ideology of Trump (Trumpology) has played an important role not just in his business and brand strategies, but also in his political rise. The (pseudo-)critical mainstream media have helped making Trump and Trumpology by providing platforms for populist spectacles that sell as news and attract audiences. By Trump making news in the media, the media make Trump. An empirical analysis of Trump's rhetoric and the elimination discourses in his NBC show The Apprentice underpins the analysis of Trumpology. The combination of Trump's actual power and Trump as spectacle, showman and brand makes his government's concrete policies fairly unpredictable. An important question that arises is what social scientists' role should be in the conjuncture that the world is experiencing.
\end{abstract}

Keywords: Donald Trump, critical theory, capitalism, political economy, Franz L. Neumann, Theodor W. Adorno, Erich Fromm, authoritarian statism, state theory, ideology critique, USA, United States politics, 2016 US presidential election

Table of Contents:

\section{Introduction}

\section{Why Did Trump Win the US Presidential Election?}

\section{Theorising the State}

\section{The Political Economy of the US State Under Trump's Rule}

4.1. The Relationship of the State to the Economy under Trump

4.1.1. Infrastructure

4.1.2. Labour

4.1.3. Healthcare

4.1.4. Climate and the Environment

4.1.5. Taxation

4.1.6. Education

4.1.7. From Millionaire Politics to Billionaire Politics

4.1.8. The State and Capitalism in Other Parts of the World 
4.2. The Relationship of the State to its Citizens: Civil Liberties and State Institutions under Trump

4.2.1. Authoritarian Statism

4.2.2. Is Trump A Fascist?

4.2.3. Law \& Order Politics

4.2.4. Opponents

4.2.5. Breitbart

4.2.6. Immigration

4.3. International Relations under Trump

4.3.1. International Relations 1: International Trade Policies

4.3.2. International Relations 2: Foreign Politics

\section{Trumpology: Ideology and the State under Trump}

5.1. Possessive Hyper-Individualism

5.2. Performance and the Ideology of Hard Labour

5.3. The Leadership Ideology

5.4. Social Darwinism \& the Friend/Enemy-Scheme

5.5. Trump and the Media

5.6. The Apprentice: Trumpology as Reality TV Spectacle

6. Conclusion: Towards a Critical Theory of Contemporary Authoritarianism, Trumpology and Trumpism

\section{References}

\section{Introduction}

On November 8, 2016, the Republican Party nominee Donald Trump, won the US presidential election against the Democratic Party's candidate Hillary Clinton. Trump is one of the richest Americans. According to statistics, he is the $156^{\text {th }}$ richest American $^{1}$. Clinton achieved 2 million votes more than Trump in the popular vote. Given the USA's majority voting system and that Trump achieved the majority in 30 out of 50 states, he won the election. Table 1 shows exit poll data.

\footnotetext{
${ }^{1}$ http://www.forbes.com/forbes-400/list, accessed on November 27, 2016.
} 


\begin{tabular}{|l|l|l|}
\hline Group & Trump & Clinton \\
\hline Men & $53 \%$ & $41 \%$ \\
\hline Women & $42 \%$ & $54 \%$ \\
\hline White & $58 \%$ & $37 \%$ \\
\hline Black & $8 \%$ & $88 \%$ \\
\hline Age 18-29 & $37 \%$ & $55 \%$ \\
\hline Age 30-44 & $42 \%$ & $50 \%$ \\
\hline Age 45-65 & $53 \%$ & $44 \%$ \\
\hline Age 65+ & $53 \%$ & $45 \%$ \\
\hline High school education or less & $51 \%$ & $45 \%$ \\
\hline Postgraduate study degree & $37 \%$ & $58 \%$ \\
\hline Income under $\$ 30,000$ & $41 \%$ & $53 \%$ \\
\hline$\$ 30,000-\$ 49,999$ & $42 \%$ & $51 \%$ \\
\hline$\$ 50,000-\$ 99,999$ & $50 \%$ & $46 \%$ \\
\hline$\$ 100,000-\$ 199,999$ & $48 \%$ & $47 \%$ \\
\hline$\$ 200,000-\$ 249,999$ & $49 \%$ & $48 \%$ \\
\hline$\$ 250,000+$ & $48 \%$ & $46 \%$ \\
\hline City over 50,000 & $35 \%$ & $59 \%$ \\
\hline Suburbs & $50 \%$ & $45 \%$ \\
\hline Small city, rural & $62 \%$ & $34 \%$ \\
\hline $\begin{array}{l}\text { Those who think that immigration is the most im- } \\
\text { portant political issue }\end{array}$ & $64 \%$ & $32 \%$ \\
\hline $\begin{array}{l}\text { Those who think that the US economy is in a poor } \\
\text { condition }\end{array}$ & $79 \%$ & $15 \%$ \\
\hline $\begin{array}{l}\text { Those whose financial situation has become worse } \\
\text { since 2012 }\end{array}$ & $78 \%$ & $19 \%$ \\
\hline Those who are angry about the federal government & $90 \%$ & $6 \%$ \\
\hline
\end{tabular}

Table 1: Exit poll showing the share of voters who fall into a specific category (data source: New York Times,

http://www.nytimes.com/interactive/2016/11/08/us/politics/election-exitpolls.html? $r=0$ )

The data indicates that the typical Donald Trump voter is an older white man, who lives in rural America, has a middle or upper income, low education, has fears about immigration and economic decline, and is angry with the government. This voting pattern is not a single case. The typical pro-Brexit voter lived in rural Britain, had a low income, low education, and was older and white (table 2).

Trump promised radical change and opposed the political elite. He managed to become the projection mechanism of the discontented and those who are afraid of social decline. Here's his typical characterisation of this elite: "Typical politician. All talk, no action. Sounds good, doesn't work. Never going to happen. Our country is suffering because people like Secretary Clinton have made such bad decisions in terms of our jobs and in terms of what's going on" (Clinton and Trump 2016a). "Finally, I realized that America doesn't need more 'all-talk, no-action' politicians running things. It needs smart businesspeople who understand how to manage. We don't need more political rhetoric - we need more common sense. 'If it ain't broke, don't fix it' - but if it is broke, let's stop talking about it and fix it. I know how to fix it " (Trump 2015a, 4). 


\begin{tabular}{|l|l|}
\hline Group & $\begin{array}{l}\% \text { of votes in } \\
\text { favour of Brexit }\end{array}$ \\
\hline Household income $>£ 60,000$ & $35 \%$ \\
\hline Household income $<£ 20,000$ & $58 \%$ \\
\hline Routine manual worker & $71 \%$ \\
\hline Higher professionals & $41 \%$ \\
\hline Not in paid work & $59 \%$ \\
\hline Postgraduate degree & $27 \%$ \\
\hline No qualifications & $75 \%$ \\
\hline Age 66+ & $59 \%$ \\
\hline Age 18-25 & $28 \%$ \\
\hline Women & $50 \%$ \\
\hline Men & $52 \%$ \\
\hline Black, Asian and minority ethnic & $36 \%$ \\
\hline White British & $52 \%$ \\
\hline
\end{tabular}

Table 2: British Election Study of voters in the EU Referendum 2016 (data source: Goodwin and Heath 2016)

What Trump suggests to do is to substitute the political elite by the economic elite so that the latter has direct influence on policy making: "[l]t's about time that this country had somebody running it that has an idea about money" (Clinton and Trump 2016a). "And if we could run our country the way l've run my company, we would have a country that you would be so proud of" (Clinton and Trump 2016c). "We have the greatest businesspeople in the world. We have to use them to negotiate our trade deals" (Clinton and Trump 2016c). The rise of Trump is the story of how a billionaire came to political power. He did not bring about a non-elitist people's politics, but the rise of the capitalist class as directly ruling and dominating politics.

This paper asks: How does the political economy of Donald Trump's presidency look like? What are the economic, political and ideological factors that will determine the character of his presidency? What changes of the US state could Trump's presidency bring about?

Section 2 focuses on the context of the rise of right-wing populism. In order to prepare the analysis of what changes of the US state Donald Trump's presidency means, section 3 discusses the concept of the state in capitalism and elaborates a theoretical model. Based on this model, section 4 analyses the political economy of the US state under Donald Trump. Section 5 gives attention to Trump and ideology. Section 6 draws some conclusions on how to apply critical theory for understanding Trump. It also asks what can be done in the political situation the world is in today.

\section{Why Did Trump Win the US Presidential Election?}

Franz Neumann (1900-1954) was a German-Jewish political scientist. After Hitler came to power, he first fled to England and then went on to the USA in 1936. At the time of the Second World, he in the years 1943-1948 worked for the Office of Strategic Services. He also worked as analyst for the prosecutors in the Nuremberg Trials. In 1948, he became a professor of political science at Columbia University. Neumann's (2009 [1944]) book Behemoth: The Structure and Practice of National Socialism 1933-1944 has become a classic work in the analysis of authoritarianism.

Neumann (1957) argues in his essay Anxiety and Politics that the rise of authoritarian politics is a combination of economic, political and psychological processes. 
Situations of anxiety in society would in such cases result in the identification of a vast amount of people with a leader. Leadership ideology would come along with the hatred of identified enemies: "Just as the masses hope for their deliverance from distress through absolute oneness with a person, so they ascribe their distress to certain persons, who have brought this distress into the world through a conspiracy. The historical process is personified in this manner. Hatred, resentment, dread, created by great upheavals, are concentrated on certain persons who are denounced as devilish conspirators" (279). In such situations, the "fear of social degradation [...] creates for itself 'a target for the discharge of the resentments arsing from damaged selfesteem"' (287). Alienation for Neumann has psychological, socio-economic and political dimensions.

Collective anxiety can emerge when one or several of the following factors are present (Neumann 1957, 288-293): a) the alienation of labour, b) destructive competition, c) social alienation: a group fears or is threatened by the decline of "its prestige, income, or even its existence" and "does not understand the historical process or is prevented from understanding it" (290), d) political alienation in respect to the political system, e) the institutionalisation of anxiety (for example in the form of a totalitarian movement, propaganda or terror), f) destructive psychological alienation and persecutory anxiety.

Neumann summarises these aspects the following way:

Neurotic, persecutory anxiety can lead to ego-surrender in the mass through affective identification with a leader. This caesaristic identification is always regressive, historically and psychologically. An important clue for the regressive character is the notion of false concreteness, the conspiracy theory of history. [...] The intensification of anxiety into persecutory anxiety is successful when a group (class, religion, race) is threatened by loss of status, without understanding the process which leads to its degradation. Generally, this leads to political alienation, i.e., the conscious rejection of the rules of the game of a political system. The regressive mass movement, once it has come to power must, in order to maintain the leader-identification, institutionalize anxiety. The three methods are: terror, propaganda, and, for the followers of the leader, the crime committed in common (Neumann 1957, 293-294).

Neumann's notions of crisis and authoritarianism can help us to understand the political situation in the USA and Europe that has developed since the start of the capitalist crisis in 2008. A first element is the alienation of labour. Neoliberal capitalism is the ruling class' struggle against everyday people that is fought via the commodification of everything, state-support for capitalist interests, and ideology. Figures 1 and 2 show the development of the wage share and the capital share in the USA and the EU. The wage share is the share of the wage sum in the GDP, the capital share the share of total capital in the GDP. The two variables are inversely proportional: The higher the capital share is, the lower is the wage share. Since the mid-1970s, the wage-share has dropped by around $5 \%$ in both the USA and the European Union. 


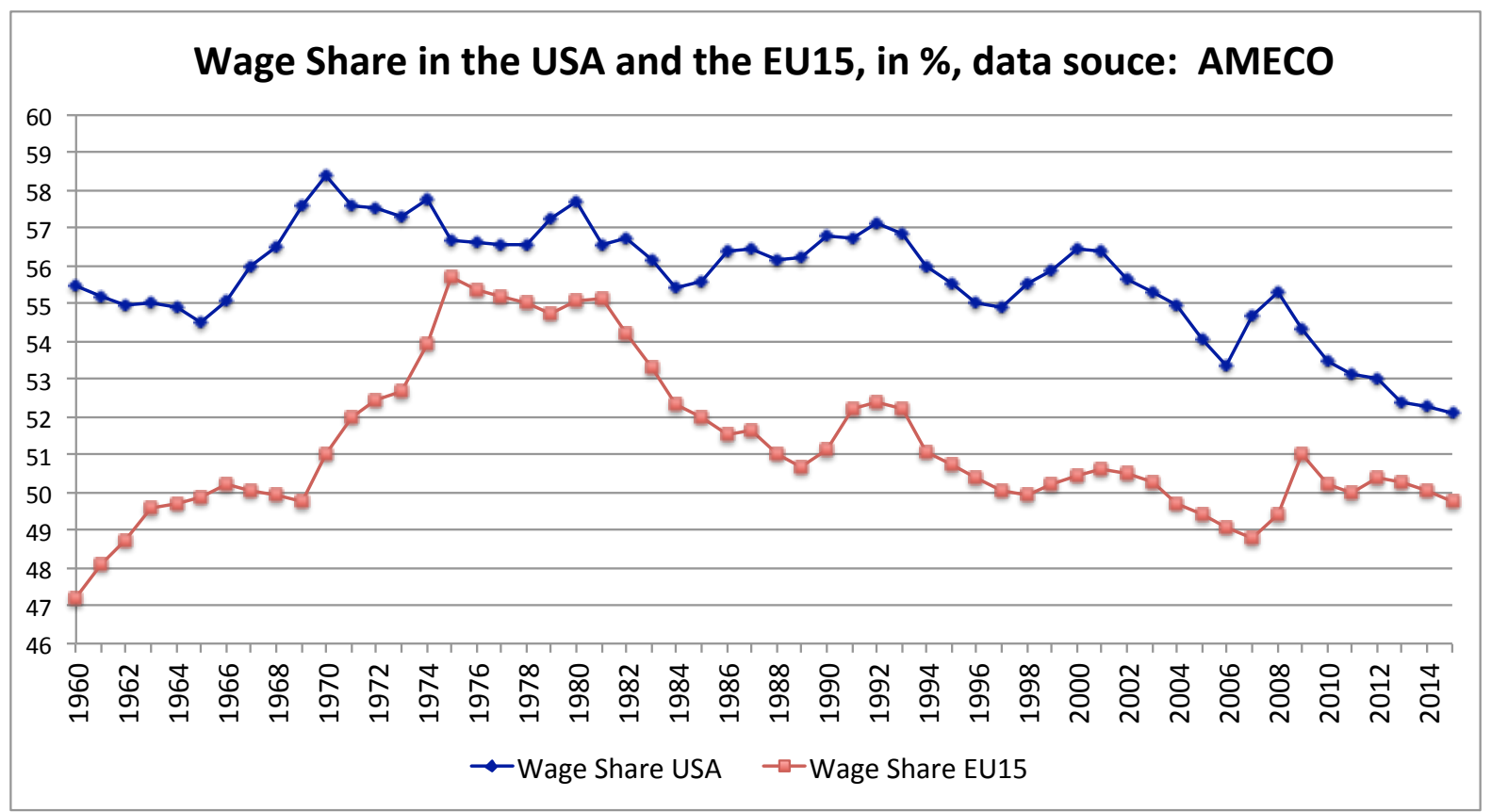

Figure 1: The wage share's development in the USA and the EU15 countries

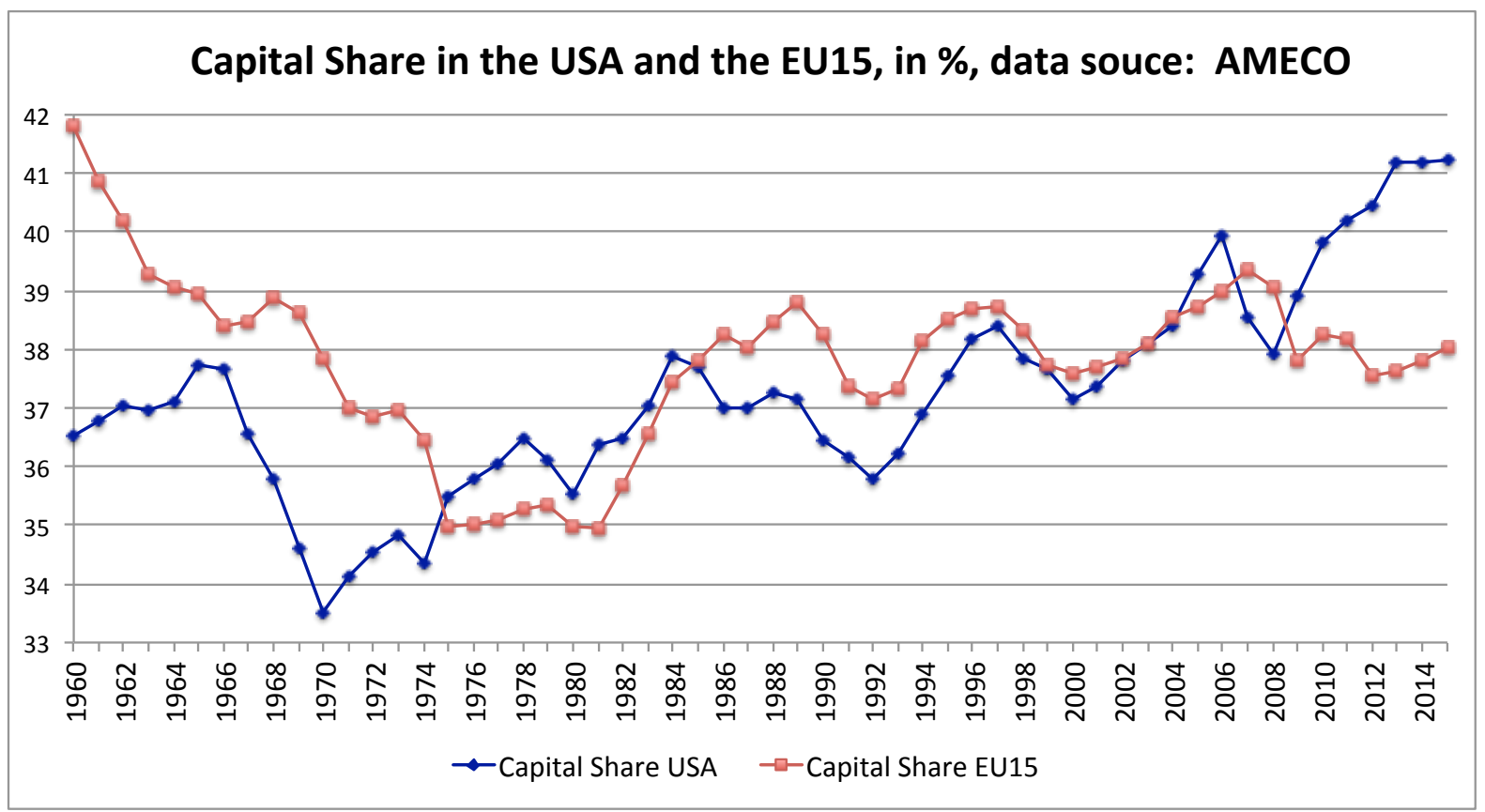

Figure 2: The capital share's development in the USA and the EU 15 countries

The rate of profit measures an economy's relationship of annual profits to investments. The rate of surplus-value is the relationship of profits to wages. The organic composition of capital is the relationship of capital investments to wages. The rate of profit is directly proportional to the rate of surplus-value and indirectly proportional to the organic composition of capital. Figures 3 and 4 show the development of these three macro-economic variables in the USA and the EU-15 countries. 


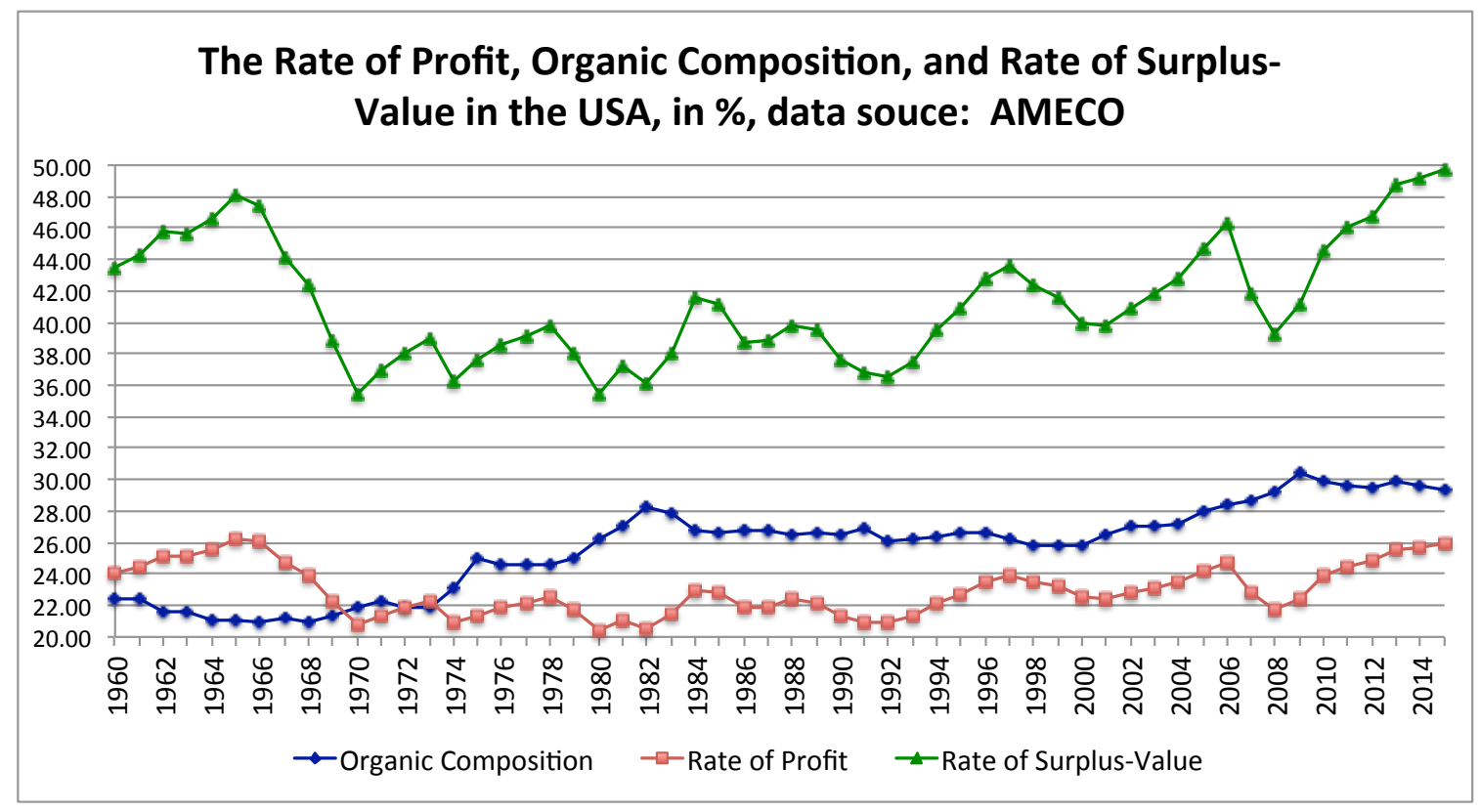

Figure 3: Macro-economic development in the USA

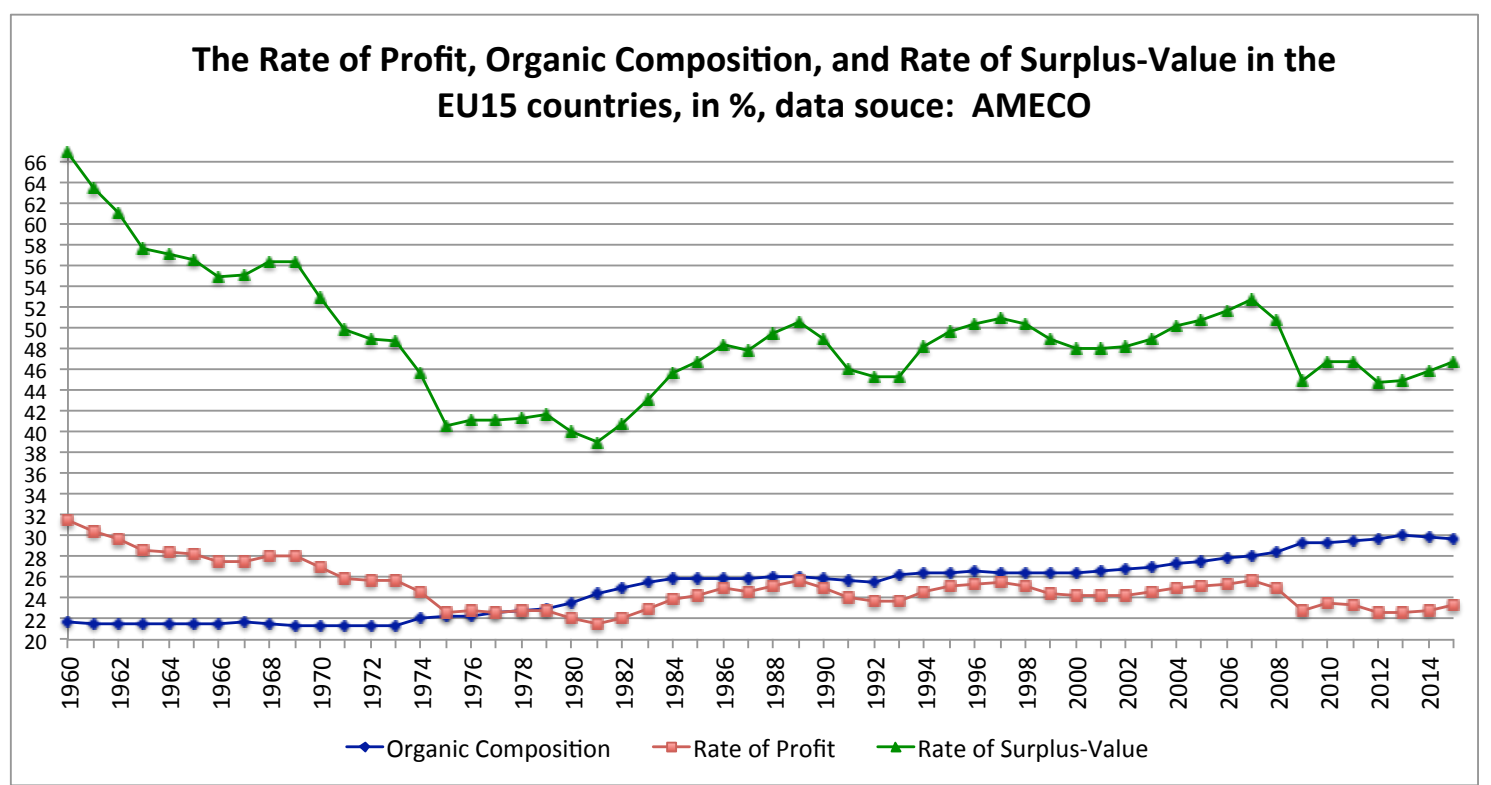

Figure 4: Macro-economic development of the EU15 countries

In the EU and the USA, the rate of surplus-value and the organic composition of capital have both increased since the mid-1970s. Given that the two variables contradict each other and exert contradictory pressures on the profit-rate, the result was that the profit rate fluctuated and could not reach the same levels as it had in the 1950s and 1960s. Pressures on wages were combined with a low-tax regime. In the USA, the level of capital taxation decreased from $0.4 \%$ of the GDP to $0.1 \%$ in 2016 (data source: AMECO).

Although capital and the capitalist state exerted downward pressure on wages, the rising costs for capital investments acted as a counter-tendency. This can be observed by an increasing organic composition of capital. Technology investments advancing the computerisation and other innovations are capital-intensive. Capital therefore tried to find other ways to increase profits. The result was an increase of the 
economy's financialisation, which included the growth of high-risk financial derivatives. According to estimations, the value of over-the-counter derivatives was in 2008 US\$ 600 trillion (Sundaram 2012). The world GDP was around US\$ 63 trillion in 2008 (data source: World Bank Statistics), which means that OTC derivatives amounted to 9.5 times the value of the global GDP. In many countries, the squeeze of wages resulted in large increases of personal debt: In the USA, the share of loans in the GDP increased from $63.0 \%$ in 1995 to $93.5 \%$ in 2008 (data source: Fuchs 2017b, table 10.1). In the UK, there was an increase from $64.0 \%$ to $93.3 \%$ during the same time period (data source: Fuchs 2017b, table 10.1). Also inequality rose massively. In 1979 , the richest 0.1 percent owned 7 percent of the total US wealth, whereas in 2016 this share had increased to 22 percent (Sanders 2016b, 207). In 2008, the US housing market's financial bubble burst, which triggered a major economic crisis. Given that financial markets are global and networked, the crisis spread and took on an international dimension.

A second factor was that international competition of transnational corporations brought about capital export and de-industrialisation in the West. In 2008, capital export (measured as foreign direct investment outward flows) accounted for $2.74 \%$ of world GDP $^{2}$. The OECD countries accounted for $81.9 \%$ of these exports. The EU $(43.6 \%)$ and the USA (19.0\%) were the largest exporters of capital. $53.9 \%$ of all FDI flows went to OECD countries, including $19.7 \%$ to the USA $(19.7 \%)$ and $20.1 \%$ to the EU (20.1\%). Other important destinations for capital exports were China $(10.9 \%)$, Russia (4.8\%), Canada (3.9\%), Australia (2.97\%), Brazil (2.87\%), India (2.76\%), and Saudi Arabia (2.51\%).

In 2015 , the share of capital export in world GDP had decreased to $2.2 \%(-0.5 \%$ since 2008). Whereas the US's share increased from $19.0 \%$ in 2008 to $20.1 \%$ in 2015, the EU's share decreased from $43.6 \%$ to $33.3 \%$. China's share increased from $3.3 \%$ to $11.7 \%$. What is also significant is that the total volume of capital export decreased from US\$ 1.4 trillion in 2008 to 1.2 trillion in 2015. The US's total volume of FDI outflows during this period shrank from 329.1 billion to 322.5 billion. The EU's total volume went from 752.4 billion down to 532.5 billion. These data provide indications that capitalism has to a significant degree de-globalised since the start of the capitalist crisis in 2008. Capitalism is still to a significant degree global capitalism, but there is a tendency that the annual increase of capital export is absolutely shrinking and slowing down relatively.

Social alienation has constituted a third factor. Given a more unequal world, many people fear a decline of their social status. The share of those US-citizens, who indicated in the World Values Survey that they are rather or completely dissatisfied with the financial situation of their household increased from $29.7 \%$ in 2000 to $36.9 \%$ in $2010^{3}$. Politics in Europe and North America reacted to the world economic crisis not by questioning, but by intensifying neoliberal governmentality: States bailed out banks and corporations with tax-payers money and implemented hyper-neoliberal austerity measures that focused on cutting expenditures for the welfare state. The bailout as such is a state-interventionist and therefore state-capitalist measure, in which the state mobilises public money in order to pay for the debt of private corporations. So this form of state-capitalist intervention turns public into private money. In 2015, the European Union under German leadership answered to the election of the

\footnotetext{
${ }^{2}$ Source for all FDI data: OECD statistics, source for world GDP data: World Bank Statistics

${ }^{3}$ Data source: World Values Survey, http://www.worldvaluessurvey.org: This item was measured with a Likert-scale ranging from 1 (completely dissatisfied) to 10 (completely satisfied). We report the sum of those whose score ranges between 1 to 5 .
} 
left-wing Syriza government in Greece with brutal financial repression. In summer 2015, it put a gun on the Greek government's head, saying, "Implement more neoliberal austerity measures or we will shoot and kill your banking system and your economy". Up until today, the EU, driven by German financial interests, refuses a haircut of Greece's debt. Greece's debt is the result of the combination of Europe's coreperiphery structure and Greek neoliberalism (Laskos and Tsakalotos 2013).

Given the decades-long persistence of politics that advance capitalist interests and squeeze everyday citizens, it is no wonder that the latter as a fourth factor feel politically alienated from the political system, political parties and politicians. Whereas in 1960 , the voter turnout in the US presidential election was $62.8 \%$ of the voting-age population, it was less than $54 \%$ in $2016^{4}$. The average turnout in EU parliamentary elections decreased from $62.0 \%$ in 1979 to $42.6 \%$ in $2014^{5}$. These are indications that citizens feel that the political system does not represent their interests. Confidence into the political systems seems to be in general low: In the World Values Survey (2010-2014 wave), $85.3 \%$ of the US participants indicated that they have low or no confidence in political parties ${ }^{6} .65 .3 \%$ indicated they had low or no confidence in the government. In an earlier wave of this survey (2005-2009), 63.6\% of the UK participants expressed low or no trust in the government and $76.9 \%$ in political parties.

The fifth factor is the institutionalisation of anxiety: Especially since the capitalist crisis started, far right populists like Donald Trump in the USA, Nigel Farage in the UK, Marine Le Pen in France, or Heinz Christian Strache in Austria have blamed immigrants and refugees and have advanced nationalist sentiments. The Austrian politician Jörg Haider was already in the 1980s a prototype of this kind of new right populist politics that play with nationalism and xenophobia (Fuchs 2016a, 2016c).

The combination of these five factors has in countries such as the UK and the USA resulted in an increase of nationalist and xenophobic sentiments and in the election of Donald Trump and the UK's decision to leave the EU.

$79 \%$ of those who voted for "Leave" in the Brexit-referendum thought that immigration was an ill for society. $71 \%$ argued that multiculturalism is bad. The levels among those who voted for Britain remaining in the EU were in contrast $19 \%$ and $20 \%$ (Ashcroft 2016). The share of "Leave" voters among those who described themselves as English and not British was 79\% (21\% "Remain" voters), whereas the share of "Remain" voters among those who saw their identity as British and not as English was $60 \%$ (40\% "Leave" voters). $84 \%$ of those who said in an exit poll that illegal immigrants working in the USA should be deported were Trump voters (Huang et al. 2016).

Another question that arises is how Trump's election could transform the US state. For trying to give an answer, we need an understanding of what the state is.

\section{Theorising the State}

State theorist Bob Jessop $(2016,49)$ argues that there are four elements of the state (Jessop 2016, 49): the state system/apparatus, the state territory, the state population, and state ideas. He defines the state the following way:

${ }^{4}$ Data sources: http://www.presidency.ucsb.edu/data/turnout.php, http://www.electproject.org/2016g

${ }^{5} \mathrm{http}: / /$ www.ukpolitical.info/european-parliament-election-turnout.htm

${ }^{6}$ Source for all data from the World Values Survey: http://www.worldvaluessurvey.org 
The core of the state apparatus comprises a relatively united ensemble of socially embedded, socially regularized, and strategically selective institutions and organizations [Staatsgewalt] whose socially accepted function is to define and enforce collectively binding decisions on the members of a society [Staatsvolk] in a given territorial area [Staatsgebiet] in the name of the common interest or general will of an imagined political community identified with that territory [Staatsidee] (Jessop 2016, 49).

In comparison to Jessop's $(1990,341)$ earlier definition of the state, his newer understanding adds a cultural dimension (the nation as imagined political community). This reflects Jessop's insight that French regulation theory, an approach that he used earlier (see Jessop 1990) and completely dropped in his 2016 book, does not adequately take into account culture and ideology and that a cultural political economy approach is needed (Sum and Jessop 2013, for a critique of this approach see Fuchs 2017a; Fuchs 2015, chapter 2). By using the concept of the imagined political community, Jessop refers to Benedict Anderson's (1991) understanding of the nation. Eric Hobsbawm in contrast to Anderson argues that nations and nationalism are invented traditions (Hobsbawm and Ranger 1983). To say that the nation and nationalism are invented differs from the claim that the nation is an imagined political community that is so large that its citizens cannot all know each other personally and therefore have to imagine shared characteristics.

Imagination has to do with creativity, which implies a positive concept of the nation, whereas critical theories of nationalism stress the nation and nationalism's ideological character. Invention resonates with fabrication, falsity, and ideology (Özkirimli $2010,107)$. One certainly must take into account that Jessop here provides a general definition of the state. But the question is whether in a democratic-socialist society a form of "civic nationalism" can exist or if not any form of nationalism always bears in itself the threat of genocide so that a free society must strive to overcome all national borders and all forms of national identity. Doubts arise whether the ideological concept of the imagined community should be included in the definition of the state.

Jessop's general definition of the state leaves out the relationship of the state to the economy. Any state relies for its existence on material inputs from the economy. Any state's collective decisions regulate the economy and society at large. In a capitalist state, these collective decisions reflect to significant degree capitalist interests. But given that a state is not necessarily capitalist and a class state, the relationship of the state to capitalism and class should not be part of the definition of the state in general, but only of the capitalist state and the class state. Jessop's definition however lacks a focus on the relationship between the economic and the political system.

If we assume that society is made up of dialectical relations of the economic, the political and the cultural realms (Fuchs 2008b, 2015, 2016b), where each realm is a realm of production and has relative autonomy, then the implication is that we need a definition of the state that focuses on the relationships of the state to the economy, politics (including self-referential relations within the state system as well as relationships to other states), and culture.

In modern society, the state regulates working conditions (labour time, wage levels, holiday entitlements, safety, etc.), ownership (monopolies, intellectual property rights, competition policies, legal defence of property against theft, etc.), monetary policies (interest rate, monetary supply), trade (protectionist VS. free market), the level and rights of the immigrant workforce; fiscal policy (taxation, government spending) in respect to a) taxation (capital, labour) and b) state spending, borrowing and 
investments in infrastructure; the private, public or hybrid ownership character of infrastructures (science and technology, schools, universities, roads, railways, bridges, hospitals, communications, housing, waste disposal, energy supply, water supply, pension system, etc.); inheritance policies, population policies (financial support for families, etc.), external and internal defence (military, police, secret services, prison system).

The officials, members and supporters of political parties to specific degrees represent the capitalist class, the working class, and different class fractions. The state is a political site, where these interests meet and contradict each other in the collective decision making process. Collective decision-making in parliaments or other political institutions is a site, where different political interests relate to each other. In capitalism, the state regulates the class conflict. It for example has positive or negative effects on profits and wages by taxation, minimum wage policies, and decisions on the public or private provision of basic services. The state's economic policies influence the rate of profit and the rate of surplus-value. Its innovation and infrastructure policies also shape the organic composition of capital. This also means that the capitalist class, the working class, ideological struggles, and the state influence class struggles. Crises of capitalism are often triggers for the restructuring of the state and its policies that regulate capitalism. Politicians are also producers of collective decisions who earn a wage paid for by taxation.

Taking these reflections into account, we can define the state as an ensemble of institutions and organisations that produce and practice collective decisions that are binding for all members of society and that thereby regulate economic, political and cultural life within the territorial boundaries of society. State power involves certain relations between the economy and the state, intra-state relations between the state's institutions, inter-state relations that define the relationship between states, semiotic representations by the state (discourses by the state), and semiotic representations of the state (discourses on the state). Table 3 present a systematic model of the state.

\begin{tabular}{|l|}
\hline Dimension \\
\hline 1) Relationship of the state to the economy \\
\hline 2) The relationship of the state to the citizens \\
\hline 3) Intra-state relations \\
\hline 4) Inter-state relations \\
\hline 5) Semiotic representations by the state (Discourses by the state) \\
\hline 6) Semiotic representation of the state (Discourses on the state) \\
\hline
\end{tabular}

Table 3: Dimensions of the state

The capitalist economy is a regime of monetary capital accumulation that is based on class relations that define and enable the private ownership of the means of production, the exploitation of labour, and the dominant class's dispossession of the products and value that labour produces. The logic of accumulation can extend beyond the economy. As a consequence, modern politics and the state are systems for the accumulation of influence and decision-power. And modern culture is an ideological system for the accumulation of reputation, meaning-making- and definition-power (Fuchs 2017b, chapter 3). Modern society therefore not just entails a capitalist economy, but is a capitalist society. A state is capitalist to the extent that its role is that it supports, enables, defends, and legitimates the accumulation of economic capital, the accumulation of political power (at the internal level of the state via mechanisms 
that allow elite control of politics, and at the international level of the state via imperialist mechanisms that allow control of the international economy, international politics, and international ideological hegemony), and the accumulation of cultural power. Culture, worldviews and ideologies matter for the state in several respects:

- The state is a site for the formulation of political positions, government programmes, and opposition programmes that express particular worldviews.

- In political institutions, different worldviews collide, contradict each other, and may also temporarily align with each other.

- Policies and political values influence and are influenced by everyday worldviews and ideologies and by intellectuals and lobbies that try to shape political programmes and positions.

Economic reductionism sees the state as the instrument for the rule of the capitalist class. It overlooks that the working class can have influence on state power. Political reductionism sees the state as autonomous and neutral institution that depending and who controls it determines the economy in particular ways. A dialectical view sees the modern state and the modern economy as identical and non-identical. They are both based on the logic of accumulation (of political power and capital). The state is always a system of political domination; class society is always a system of exploitation. The state as the site of political accumulation and domination stands in a contradictory relation to the capitalist economy as the site of economic accumulation and exploitation.

Given this model of the state, we can next analyse how US state power may change under Donald Trump.

\section{The Political Economy of the US State Under Trump's Rule}

This section has sub-sections that reflect the state model outlined in section 3 :

4.1. The Relationship of the State to the Economy under Trump

4.2. The Relationship of the State to its Citizens: Civil Liberties and State Institutions under Trump

4.3. International Relations under Trump

4.4. Trumpology: Ideology and the State under Trump

Note that dimension two and three of the state model (relationship of the state to citizens, intra-state relations) have been combined. Both relate to the political system's internal organisation, focusing on a) the relationship of the state to civil society and b) the relationship among state institutions. The first dimension covers the relationship of the state to the economy. The model's fifth and sixth dimension focus on the relationship of the state to culture and have also been combined. The culturalideological dimension analyses ideological representations by the state and of the state in the age of Trump.

\subsection{The Relationship of the State to the Economy under Trump}

The state regulates the capitalist economy, depends on it, and at the same time has relative autonomy from it. The tightness or looseness of the coupling between the capitalist economy and the state depends on specific political, cultural and ideological conditions and the temporary results of social conflicts and struggles. "[S]tate power is capitalist to the extent that it creates, maintains or restores the conditions required for capital accumulation in a given circumstances and is non-capitalist to the extent that these conditions are not realized" (Jessop 1990,117). The political elite can at certain times operate relatively autonomously from the capitalist class's influence and 
shape the development of the capitalist economy, especially if there is a socialist government.

Jessop $(1990,150)$ assumes that there is an "institutional separation of the economic and political" so that one "cannot reduce state power to questions of the class background, affiliation or sympathies of the state elite". "The separation of the economic and the political orders excludes an immediate isomorphism between economic class relations and relations among political categories. Indeed the legitimacy of the modern state would disappear if the state unequivocally served the immediate economic interests of the dominant class(es)" (Jessop 2016, 102). The question is whether this relation is changing under Trump.

The tradition of state theory that Jessop represents assumes that the economy and politics are relatively separate and autonomous. The theory of state monopoly capitalism (Stamocap) in contrast takes a more traditional approach, in which the economy largely determines the political system. It defines the state as a foundational structure and the mode of functioning of modern capitalist society. Key characteristics of state monopoly capitalism are:

- "a high degree of concentration, centralisation and monopolisation of private capital;

- the bourgeois state's steady and extensive presence and intervention into the economic reproduction process;

- significant influence of the leading monopolies on state policies regulating the economy and other realms of society" (Huffschmid 1990, 758).

"By the interlocking of and relations between the state and corporations and influences by the latter on the first, the leading corporations' interests influence and shape state politics to a great degree" (Huffschmid 2010,148). This influence would take on the form of corporate lobbying; the strategic role of corporations in cities, regions and countries; and the exchange of personnel between the state and corporations, i.e. between political and economic elites. Stamocap theories assume that the state acts on behalf of capitalist monopolies' interests and that the class affiliations of the state's officials are key. State officials would be political representatives of monopoly capital's interests. In state monopoly capitalism, there would be heavy state intervention (including nationalisation) to support monopolies because the profit rate would tend to fall,

One problem of many Stamocap theories is that they assume that state monopoly capitalism results in the breakdown of capitalism and the transition to socialism. Paul Boccara (1982) stresses in this context the role of state intervention, the nationalisation of industries, new transport and communication technologies, intellectual labour, cybernetics, and automation. He argues that in the state monopoly stage, capitalism reaches the "uttermost limit" of its decay. "Collective ownership and the socialist plan become immediately necessary for economic practice" (103, translation from German). We of course know today that state capitalism and the information economy have not given rise to a post-capitalist society. Rather state monopoly capitalism was followed by yet another stage of capitalist development, namely neoliberal capitalism.

Jörg Huffschmid (2010, 149-151), who in the 1960s and 1970s was one of West Germany's leading Stamocap theorists, argues that Stamocap theories overlook that also small and medium sized companies can play an important role in capitalism's development, that capital's interests and the state are contradictory, that the internationalisation of capital poses challenges for Stamocap theories, and that the environmental crisis and patriarchy cannot be reduced to the role of monopolies in capitalism. 
Stamocap theories have been criticised for reducing the state to an instrument of the monopoly bourgeoisie and for thereby advancing an economic-reductionist and monolithic approach that overlooks that the state is itself a realm, in which conflicts between classes and class factions are politically fought out and condensed into temporary, fragile unity and alliances (Hirsch, Kannankulam and Wissel 2015).

The approaches of Antonio Gramsci, Nicos Poulantzas and other materialist theories of the state assume in contrast a relative autonomy of the state and capitalism. The question, however, arises in this context how the phenomenon of Donald Trump can be explained based on the assumption of relative autonomy, as his victory in the US presidential election seems to be indicative for a temporary close coupling and overlap of the US's economic and the political system. Whereas state monopoly capitalism cannot explain the state's relative autonomy from capital in other situations, relative autonomy theories cannot well explain Donald Trump.

Stamocap theories tend to assume that the capitalist economy and the capitalist state interlock and interact functionally, institutionally and in respect to personnel. It tends to, however, stress that both realms remain separate because otherwise the orthodox assumption that the economic base determines the political and ideological superstructure cannot be upheld (see IMSF 1981, 226-244). Interlocking and interaction would take place in the form of committees, boards, lobbying organisations, industry associations, consultancies, bourgeois academia and science, bourgeois media, research groups, working groups, etc. (IMSF 1981, 257-276). The state's leading group of career politicians would have specific career paths separate from the ones of the capitalist class. The contact between the two would take on the form of "working groups, contact groups, research groups" and institutions (IMSF 1981, 274).

Relative autonomy theories and Stamocap theories cannot adequately explain the fact that Donald Trump is both a capitalist, who is among the richest Americans, and US president. There is a direct overlap between monopoly capital and the state in the form of one person, who is among the most powerful capitalists and has become the world's most powerful politician. Trump is not a career politician, but a politicianturned-capitalist, who fuses economic and political interests in one person. Trump says in this context: "I am the richest presidential candidate in history. I'm the only billionaire ever to run" (Trump 2015a, 148).

There is always a dialectic of the state and the economy in capitalism, but this relationship involves a specific power distribution that is dynamic and can shift historically. Franz Neumann $(1957,12)$ argues in this context that politics and the economy are always dialectically interconnected: "Economics is as much an instrument of politics as politics is a tool of economics". The specific relation between the two realms depends on society's historical context (Neumann 1957, 14). So for example in Nazi Germany, there was the primacy of the state over the economy. In the Keynesian state, there is an interaction of two poles of power. In the neo-liberal state, there is a primacy of the economy over the state via structural mechanisms. In the Trump state, there may be a primacy of the economy over the state via a politician-turnedcapitalist.

Keynesian capitalism as a democratic form of state-monopoly capitalism ruled in Western capitalist societies until the 1970s and was then gradually supplanted by neo-liberal capitalism that privatised state-owned industries and reduced the level of state intervention into specific parts of the economy. The rise of neoliberal capitalism stood in the context of the crisis of Fordism and the crisis of the Keynesian state. Two important changes that the emergence of neoliberal capitalism brought about were the privatisation of state-owned industries and the internationalisation of capitalism 
that brought about competition states. The role of finance capital and new technology capital increased. The role of classical industry in capitalism was reduced. The role of the capitalist state shifted in light of these transformations. States compete for deregulating the welfare state and social protection in order to attract capital. This does, however, not mean that state power has been weakened. It has merely been transformed and changed its role. Capital's structural and indirect influence as collective political actor on the state has been strengthened. In neoliberal capitalism, state politics primarily focus on a) the politics of privatisation, deregulation, market liberalisation, low-tax- and free trade-policies in order to enable commodification; $b$ ) the politics of militarisation and securitisation in order to exert international and national control that protects the overall political-economic system.

Yet another shift of the role of the state was indicated by the bailout of banks and corporations in the course of the capitalist crisis that started in 2008. Nation states strongly intervened into the economy by saving crisis-struck finance capital and capital in the car industry with taxpayers' money. Results of this interventionist move were hyper-neoliberal austerity politics that hit the poorest and weakest in society and further advanced inequalities.

There is certainly always an institutional separation of the capitalist state and the capitalist economy, which means that both systems have different organisations, logics, rules, and structures. However, at times there can be direct overlap of personnel so that capitalists become part of the ruling political elite. Donald Trump as US president constitutes an important transition so that there is a key personnel overlap between the capitalist class and the political elite. With the rise of Donald Trump to the USA's head of state, there is now a much more direct influence of the capitalist class on political power because there is an overlap of personnel in the form of the President, who is also a billionaire capitalist.

John Bellamy Foster and Robert W. McChesney (2012) explain the rise of multinational corporations with capital's attempt to overcome long-term economic stagnation and to attain global monopoly profits. Multinationals aim to drive down the wage share globally and increase their profits by installing a system of global competition among workers. The consequence is a worldwide increase in the rate of exploitation that Foster and McChesney, drawing on Stephen Hymer's work, call a "strategy of divide and rule" (Foster and McChesney 2012, 114-115, 119). Foster $(2006,11)$ argues that monopoly-finance capitalism is a "new phase" of capitalist development. He explains its genesis:

At the brink of the twentieth century, capitalism underwent a major transformation, marked by the rise of the giant corporation. The early decades that followed were dominated by world wars and a depression associated with this great transformation. Following the Second World War the new stage of capitalism was fully consolidated, particularly within the United States, the most advanced capitalist economy. The result was a situation in which a handful of giant corporations controlled most industries (Foster 2006, 2).

Financialization can be defined as the shift in the center of gravity of the capitalist economy, from production to finance. [...] Growth of finance relative to the real economy also meant the appearance of financial bubbles that threatened to burst. [...] Economic power was shifting from corporate boardrooms to financial institutions and markets, affecting the entire capitalist world economy in complex ways, through a process of financial globalization. [...] The growing role of 
finance was evident not just in the expansion of financial corporations but also in the growth of the financial subsidiaries and activities of non-financial corporations, so that the distinction between the financial and non-financial corporations, while still significant, became increasingly blurred. Financialization in the 1980s and '90s was the main new force in the much longer-term globalization process, and was the defining element in the whole era of neoliberal economic policy (Foster 2010, 5-6).

This ballooning of finance produced new outlets for surplus in the finance, insurances, and real estate (FIRE) sector of GDP in the form of new investment in buildings, office equipment, etc. Nevertheless, the great bulk of the money capital devoted to finance was used for speculation in securities, real estate, and commodities markets rather than for investment in capital goods, and thus did not feed into the growth of GDP, which continued to stagnate (Foster 2006, 4$5)$.

\begin{tabular}{|c|c|c|}
\hline Company Name & Minimum Value & Company and Revenue Type \\
\hline 40 Wall Street LLC & $\$ 50,000,000.00$ & Commercial real estate, rent \\
\hline 401 North Wabash Venture LLC & $\$ 50,000,000.00$ & $\begin{array}{l}\text { Residential and commercial real estate, rent, condo } \\
\text { sales }\end{array}$ \\
\hline OJT Operations & $\$ 50,000,000.00$ & Aircraft, rent \\
\hline Fifty-Seventh Street Associates LLC & $\$ 50,000,000.00$ & Real estate, rent \\
\hline Trump National Golf Club - Jupiter & $\$ 50,000,000.00$ & Golf club \\
\hline Trump National Golf Club - Bedminster & $\$ 50,000,000.00$ & Golf club \\
\hline Mar-a-Lago Club, L.L.C. & $\$ 50,000,000.00$ & Resort \\
\hline Trump Turnberry & $\$ 50,000,000.00$ & Golf courses and resort \\
\hline The Trump Corporation & $\$ 50,000,000.00$ & Management company \\
\hline Trump National Doral & $\$ 50,000,000.00$ & Golf courses \& resort \\
\hline Trump International Golf Links - Scotland & $\$ 50,000,000.00$ & Golf course \\
\hline $\begin{array}{l}\text { Trump International Hotels Management } \\
\text { LLC }\end{array}$ & $\$ 50,000,000.00$ & Management company \\
\hline Trump National Golf Club - Colts Neck & $\$ 50,000,000.00$ & Golf club \\
\hline Trump National Golf Club - Westchester & $\$ 50,000,000.00$ & Golf club \\
\hline Trump National Golf Club - Washington DC & $\$ 50,000,000.00$ & Golf club \\
\hline Trump Old Post Office LLC & $\$ 50,000,000.00$ & Hotel \\
\hline Trump Park Avenue LLC & $\$ 50,000,000.00$ & $\begin{array}{l}\text { Residential \& commercial real estate: Rent, condo } \\
\text { sales }\end{array}$ \\
\hline Trump Ruffin Tower I LLC & $\$ 50,000,000.00$ & $\begin{array}{l}\text { Commercial real estate, condo sales, hotel related } \\
\text { revenue }\end{array}$ \\
\hline Trump Tower Commercial LLC & $\$ 50,000,000.00$ & Commercial real estate, rent \\
\hline Trump National Golf Club - Los Angeles & $\$ 50,000,000.00$ & $\begin{array}{l}\text { Golf course and unsold lots, golf related revenue } \\
\text { land sales }\end{array}$ \\
\hline HWA 555 Owners, LLC & $\$ 50,000,000.00$ & Commercial real estate, rent \\
\hline 1290 Avenue of the Americas. & $\$ 50,000,000.00$ & Commercial real estate, rent \\
\hline Trump Tower Triplex & $\$ 50,000,000.00$ & Residential real estate \\
\hline Total: & $>\$ 1,150,000,000.00$ & \\
\hline
\end{tabular}

Table 4: Donald Trump's companies that have a value of at least US\$ 50 million (Data source: Donald Trump Executive Branch Personnel Public Financial Disclosure Report, OGE Form 278e, date: May 16, 2016) 
For reflecting on how US capitalism may change under Trump, we need to better understand Trump's economic empire. According to the Forbes list of the world's billionaires, Trump was in 2016 with an estimated wealth of US $\$ 4.5$ billion the $324^{\text {th }}$ richest billionaire ${ }^{7}$. Measuring the exact extent of Trump's wealth has been a matter of controversy (O'Brien 2016).

The Trump Organization builds, owns and operates real estate, towers and skyscrapers, hotels, golf courses, casinos, residential towers; luxury-, entertainment- and leisure-resorts. Trump also owns Trump Productions LLC that produces the reality TV show The Apprentice that Donald Trump hosted from 2004 until 2015. Table 4 shows, according to a financial disclosure statement, Trump's ownership involvement in companies with a value larger than US\$ 50 million around the time he ran for US president.

Table 5 shows according to a 2016 financial disclosure examples of industries with which Donald Trump's economic activities interlocked via investments and share ownership. Industries outside his core economic area of real estate and entertainment into which he has invested, include for example finance, natural resource extraction, utilities, transport, health, biotechnology, food, retail, telecommunications, or Internet.

\begin{tabular}{|l|l|}
\hline Industry & Example Companies \\
\hline Agricultural products and services & Agrium \\
\hline Clothing & Nike, VF Corporation \\
\hline Computer hardware and software & Apple, Cisco, General Electric, Intuit, Microsoft \\
\hline Defence & Raytheon \\
\hline Electronic instruments & Ametek, Parker Hannifin, Roper Technologies \\
\hline Finance & $\begin{array}{l}\text { Advantage Advisers Xanthus Fund, AG Eleven Partners LP, } \\
\text { Ameriprise Financial, Baron Growth Fund, Baron Partners } \\
\text { Fund, Baron Real Estate Fund, BlackRock, Caterpillar, } \\
\text { Citigroup, Deutsche Money Market Series, Deutsche X- } \\
\text { trackers MSCI Hedged Equity, Discover Financial Services, } \\
\text { General Electric, Invesco European Grow, JPMorgan Chase, } \\
\text { MidOcean, Paulson \& Co, Prudential Financial, Swiss Re, } \\
\text { Vanguard, Visa, Wells Fargo }\end{array}$ \\
\hline Food and consumer products & $\begin{array}{l}\text { Ecolab, Kraft Heinz, Mead Johnson, PepsiCo, Procter \& Gam- } \\
\text { ble, Sealed Air, WhiteWave Foods }\end{array}$ \\
\hline Health and biotechnology & $\begin{array}{l}\text { Ecolab, General Electric, Gilead Sciences, Hospital Corpora- } \\
\text { tion of America, Johnson \& Johnson, McKesson Corporation, } \\
\text { Merck \& Co, Pfizer, Thermo Fisher Scientific }\end{array}$ \\
\hline Media content & Comcast, Twenty First Century Fox \\
\hline $\begin{array}{l}\text { Natural resource extraction and } \\
\text { sale, utilities }\end{array}$ & $\begin{array}{l}\text { American Water Works, bhpbilliton, Chevron, ConocoPhillips, } \\
\text { EOG Resources, Exxon Mobil, Freeport-McMoRan, General } \\
\text { Electric, Halliburton, NextEra Energy, Phillips 66, Royal Dutch } \\
\text { Shell, Schlumberger, Total S.A., Valero Energy }\end{array}$ \\
\hline Pulp and paper & International Paper \\
\hline Retail and wholesale & Costoco Wholesale, Home Depot, L Brands Inc, TJX, Walmart \\
\hline Storage & Extra Space Storage \\
\hline $\begin{array}{l}\text { Telecommunications and Internet } \\
\text { infrastructure }\end{array}$ & $\begin{array}{l}\text { AT\&T, CenturyLink, Comcast, Crown Castle, General Electric, } \\
\text { Telenor, Verizon Communications }\end{array}$ \\
\hline Transport & Boeing, Borg Warner, Caterpillar, Norfolk Southern Railway \\
\hline
\end{tabular}

Table 5: Donald Trump's connections to other industries and companies via shareholding (Data source: Donald Trump Executive Branch Personnel Public Financial Disclosure Report, OGE Form 278e, date: May 16, 2016)

\footnotetext{
${ }^{7}$ http://www.forbes.com/billionaires/list/, accessed on November 28, 2016.
} 
Given the Trump empire's interlocking with core sectors of US capitalism, it is interesting to have a look at how Trump stands on policies that affect these industries.

\subsubsection{Infrastructure}

Trump's campaign said that he wants to start a massive project for the construction of infrastructure. "Our airport, bridges, water tunnels, power grids, rail system - our nation's entire infrastructure - is crumbling, and we aren't doing anything about it" (Trump 2015a, 120). The programme includes to:

- "Create thousands of new jobs in construction, steel manufacturing, and other sectors to build the transportation, water, telecommunications and energy infrastructure needed to enable new economic development in the U.S., all of which will generate new tax revenues.

- Put American steel made by American workers into the backbone of America's infrastructure.

- Leverage new revenues and work with financing authorities, public-private partnerships, and other prudent funding opportunities"

So the idea is that the state invests into the construction of infrastructure. But given that taxpayers' money will be used, it is not obvious in this plan that this will be publicly owned infrastructure. It rather seems that fostering public-private partnerships could mean that the state pays for infrastructure projects that are carried out by private companies that then also own this infrastructure. So it could very well turn out that the state is neither the employer of infrastructure workers nor the owner of newly built infrastructures, but only the financer, which basically means the tax-funded creation of profits and private property. The very question that arises is whether in the case where taxpayers' money is used for investments, the created resources should be owned publicly or privately. Such projects clearly benefit the real estate industry that Trump comes from.

\subsubsection{Labour}

Trump appointed Andrew F. Puzder as secretary of labour. Puzder is the CEO of CKE Restaurants that owns the fast food chains Carl's Jr., Hardee's, Green Burrito and Red Burrito. Fast food jobs tend not to be very well paid, which is why the demand for a living wage of US\$15 per hour has especially arisen in this industry. California has passed a law to increase the minimum wage to US\$15 until 2022. Puzder opposes such an increase (Hiltzik 2016).

In 2014, Puzder spoke out against minimum wage increases from US\$ 7.25 to US\$ 10.10:

Unfortunately, this $40 \%$ minimum-wage hike would also reduce employment opportunities for those who need them most. [...] Let's examine how it would affect a restaurant franchisee, a typical small business owner attempting to run a profitable enterprise. My company, CKE Restaurants, has more than 200 franchisees running about 2,000 restaurants nationwide. Our typical franchised restaurant employs 25 people and earns about $\$ 100,000$ a year in pretax profit about $8 \%$ of the restaurant's $\$ 1.2$ million annual sales. [...] But here's what middle-class business owners, who live in the real world, will do when faced with a $40 \%$ increase in labor costs. They will cut jobs and rely more on technology. Such changes are already happening in banks, gas stations, grocery

\footnotetext{
${ }^{8}$ https://www.donaldjtrump.com/policies/an-americas-infrastructure-first-plan/
} 
stores, airports and, more recently, restaurants. Almost every restaurant chain in the country from Applebee's to McDonald's is testing or already implementing automated ordering with tablets or kiosks. The only other option is to raise prices. Yet it would be near-impossible to increase prices enough to offset the wage hike, particularly given today's economic conditions (Puzder 2014).

When wages increase, Puzder only sees two possible responses by companies, namely that they either increase prices or try to enforce automation in order to lay off workers. The point is that he leaves out the option that companies accept lower profit rates. This does not seem to be an option for Puzder because he represents the interest of capital and not of labour. It is quite likely that a businessman as secretary of labour will do anything to keep minimum wages low, to limit their increase and to limit the power of workers. A law taxing machinery that comes along with minimum wage increases could easily secure avoiding wage-increase-based incentives for automation. In the light of Puzder's appointment, it seems likely that Trump's goal of keeping capital in and attracting capital to the USA is not a project that is concerned about good earnings for workers, but is all about growing corporations' profits.

Given that fast food jobs are highly alienated labour, automating these activities should not automatically be dismissed. The point is that well paid skilled jobs are needed. But the USA's elitist higher education system plunges young people and their parents into debt. Neoliberal capitalism enforces low paid, precarious labour. Progressive forms of automation must therefore stand in the context of discussions about how to secure a good life for all, for example in the form of a basic income guarantee that is funded out of capital taxation (Fuchs 2008a).

\subsubsection{Healthcare}

Trump opposes Obama's health reform and wants to advance what he terms consumer-driven healthcare. "Bad health care at the most expensive price. We have to repeal and replace Obamacare" (Clinton and Trump 2016c). "We want competition. You will have the finest health care plan there is" (Clinton and Trump 2016b). Trump's plan includes to:

- "Repeal and replace Obamacare with Health Savings Accounts (HSAs). [...]

- Allow people to purchase insurance across state lines, in all 50 states, creating a dynamic market. [...]

- President Obama said his health plan would cut the cost of family premiums by up to $\$ 2,500$ a year. Instead, premiums have gone up by almost $\$ 5,000$ since Obamacare passed. [...]

- Premiums have skyrocketed across the nation, with a national average of almost $25 \%$, with some states experiencing rate increases up to $70 \%$. [...]

- People are going without needed medical care because they can't afford these amounts"9.

The argument that capitalist competition makes things cheaper is not automatically true, as the privatisation of railways in the United Kingdom and of telecommunications in the EU shows. Capitalism has an inherent monopoly tendency so that forprofit orientation and competitive markets tend to result in oligopolies and monopolies. If there is a private health insurance market, then the goal of the involved com-

\footnotetext{
${ }^{9}$ https://www.donaldjtrump.com/policies/health-care/
} 
panies is to maximise profits. The way to do this is to aim at keeping the number and level of insurance claims low. Michael Moore's (2007) film Sicko illustrates that privatised health care can result in health insurances' denials to cover costs. If health insurance in contrast is a public service funded out of contributions paid in by employees and employers, then the logic of insurance denial can more easily be avoided. Only a public health system can guarantee universal coverage and access. A private for-profit system puts patients at the whims of private insurances that want to increase their profits.

Trump's interest in fostering private health care may not just result from the fact that he as shareholder had himself business interests in this industry, but it may very well come from a general ideological conviction that health and other social services should be organised as capitalist businesses that accumulate capital.

\subsubsection{Climate and the Environment}

\begin{tabular}{|c|c|c|c|}
\hline & 1996 & 2007 & 2016 \\
\hline $\begin{array}{l}\text { Share of the top } 500 \\
\text { companies' revenues in } \\
\text { the US-GDP }\end{array}$ & $57.9 \%$ & $68.4 \%$ & $65.4 \%$ \\
\hline $\begin{array}{l}\text { Largest industry's share } \\
\text { in the Fortune } 500 \text { com- } \\
\text { panies' total profits }\end{array}$ & Finance $25.2 \%$ & Finance $29.4 \%$ & $\begin{array}{l}\text { Information, communication \& } \\
\text { computing } 27.3 \%\end{array}$ \\
\hline $\begin{array}{l}2^{\text {nd }} \text { largest industry's } \\
\text { share }\end{array}$ & Energy $13.7 \%$ & Energy $18.8 \%$ & Finance $26.8 \%$ \\
\hline $\begin{array}{l}3^{\text {rd }} \text { largest industry's } \\
\text { share }\end{array}$ & Transport $11.1 \%$ & $\begin{array}{l}\text { Information, } \\
\text { communication } \\
\& \text { computing } \\
13.7 \%\end{array}$ & $\begin{array}{l}\text { Health, pharmaceuticals \& bio- } \\
\text { tech } 14.2 \%\end{array}$ \\
\hline $\begin{array}{l}4^{\text {th }} \text { largest industry's } \\
\text { share }\end{array}$ & $\begin{array}{l}\text { Information, } \\
\text { communication \& } \\
\text { computing } 10.3 \% \\
\end{array}$ & $\begin{array}{l}\text { Health, phar- } \\
\text { maceuticals \& } \\
\text { biotech } 9.5 \%\end{array}$ & Transport $11.9 \%$ \\
\hline $\begin{array}{l}5^{\text {th }} \text { largest industry's } \\
\text { share }\end{array}$ & $\begin{array}{l}\text { Health, pharma- } \\
\text { ceuticals \& bio- } \\
\text { tech } 8.7 \%\end{array}$ & Food $5.7 \%$ & Food $8.6 \%$ \\
\hline $\begin{array}{l}\text { Share of hotel, restau- } \\
\text { rant \& leisure industry }\end{array}$ & $0.6 \%$ & $1.3 \%$ & $1.8 \%$ \\
\hline $\begin{array}{l}\text { Share of engineering \& } \\
\text { construction industry }\end{array}$ & $-0.2 \%$ & $0.9 \%$ & $0.6 \%$ \\
\hline $\begin{array}{l}\text { Share of real estates } \\
\text { industry }\end{array}$ & $0 \%$ & $0.2 \%$ & $0.5 \%$ \\
\hline
\end{tabular}

Table 6: Share of the 500 largest companies' revenues in the USA's GDP, share of specific industries' profits in the total profits of the USA's 500 largest companies (data sources: Fortune US 500 [revenues, profits], various years; OECD Stat \& BEA [GDP])

Table 6 shows the development of the share of the 500 largest US companies in the countries total GDP. Given that the share has increased from $57.9 \%$ in 1996 to $65.4 \%$ in 2016 , we can say that American capitalism has become more monopolistic. The data show that the information, finance, health/pharmaceuticals/biotech, transport, food and energy industries form US capitalism's key sectors. It may therefore not be an accident, but a business strategy that Donald Trump has exactly invested in these sectors. 
According to the data used in table 6 , the US energy industry made massive losses in 2016. The combined loss of the largest energy companies was US\$ 44.4 billon. These included companies such as Apache (US\$ -23.1 billion), Chesapeake Energy (-14.7 bn), Devon Energy (-14.5 bn), Freeport-McMoRan (-12.2 bn), Occidental Petroleum (-7.8 bn), Anadarko Petroleum (-6,7 bn), NRG Energy (-6.4 bn), Energy Future Holdings ( -5.3 bn), EOG Resources ( -4.5 bn), ConocoPhillips ( $-4.4 b n)$, Hess ($3.1 \mathrm{bn})$, Marathon Oil (-2.2 bn), Baker Hughes (-2.0 bn), or Peabody Energy (-2.0 bn).

The Wall Street Journal observed: "Low fuel prices and new climate policies are rapidly transforming the American energy sector, while escalating wars in the Middle East and a nuclear deal with Iran are clouding the global oil picture. [...] What's harder to develop is the political consensus to transition to pricing carbon emissions. Right now, climate policy is being implemented piecemeal around the world. That, combined with current low oil and gas prices, has increased the investment risk associated with future energy production" (Cook 2015).

Trump's says he favours oil and coal in energy politics over alternative forms of energy:

We invested in a solar company, our country. That was a disaster. They lost plenty of money on that one. Now, look, I'm a great believer in all forms of energy, but we're putting a lot of people out of work. Our energy policies are a disaster. Our country is losing so much in terms of energy, in terms of paying off our debt. You can't do what you're looking to do with $\$ 20$ trillion in debt. [...] There has been a big push to develop alternative forms of energy - so-called green energy - from renewable sources. That's a big mistake. To begin with, the whole push for renewable energy is being driven by the wrong motivation, the mistaken belief that global climate change is being caused by carbon emissions. If you don't buy that - and I don't - then what we have is really just an expensive way of making the tree-huggers feel good about themselves. [...] Until we get this country's lifeblood - oil - back down to reasonable rates, America's economy will continue to slump, jobs won't get created, and American consumers will face ever-increasing prices ${ }^{10}$.

Our first priorities need to be approving the Keystone XL Pipeline and starting to drill everywhere oil is accessible. There has been a big push to develop alternative forms of energy - so-called green energy - from renewable sources. That's another big mistake. To begin with, the whole push for renewable energy is being driven by the wrong motivation, the mistaken belief that global climate change is being caused by carbon emissions. If you don't buy that - and I don't - then what we have is really just an expensive way of making the tree-huggers feel good about themselves (Trump 2015a, 65).

On November 6, 2012, Trump voiced climate change scepticism on Twitter: "The concept of global warming was created by and for the Chinese in order to make U.S. manufacturing non-competitive". His election campaign announced that it wants to "[u]nleash America's $\$ 50$ trillion in untapped shale, oil, and natural gas reserves, plus hundreds of years in clean coal reserves" ${ }^{11}$. He made it clear that he favours not just

\footnotetext{
${ }^{10} \mathrm{http}: / /$ www.ontheissues.org/2016/Donald_Trump_Energy + Oil.htm

11 https://www.donaldjtrump.com/policies/energy/
} 
oil, but also coal: "[E]nergy is under siege by the Obama administration. [...] we need much more than wind and solar. [...] Hillary Clinton wants to put all the miners out of business. There is a thing called clean coal. Coal will last for 1,000 years in this country. Now we have natural gas and so many other things because of technology. [...] I will bring our energy companies back. They'll be able to compete. They'll make money. They'll pay off our national debt. They'll pay off our tremendous budget deficits, which are tremendous" (Clinton and Trump 2016b).

After the election, Tump said in a New York Times interview about climate change: "I have an open mind to it. We're going to look very carefully. It's one issue that's interesting because there are few things where there's more division than climate change. [...] I think there is some connectivity [between human activity and climate change]. There is some, something. It depends on how much. It also depends on how much it's going to cost our companies. You have to understand, our companies are noncompetitive right now" (Trump 2016b)

Trump in general favours deregulation. "The misguided passion of environmentalists today makes building anything much more difficult. Now we have crazy overregulation. You can barely buy a paper clip without being in violation of some governmental policy" (Trump 2015a, 82). Trump appointed Scott Pruitt as head of the Environmental Protection Agency. The New York Times argues that Pruitt as Oklahoma attorney general worked "with some of the largest oil and gas companies, and the state's coal-burning electric utility, to try to overturn a large part of the Obama administration's regulations on air emissions, water pollution and endangered animals" (Davenport and Lipton 2016). Pruitt and Strange (2016) say about climate change: "Scientists continue to disagree about the degree and extent of global warming and its connection to the actions of mankind. That debate should be encouraged".

Trump's focus on the oil industry may not just result from the fact that he as shareholder had himself business interests in this industry, but it may very well come from a general ideological belief that the oil industry is needed as US capitalism's driver. Given his opposition to green energy, it could very well be that Trump's environmental policies will foster an increase of carbon dioxide emissions and environmental pollution.

\subsubsection{Taxation}

Trump promises low taxes for corporations: "The Trump Plan will lower the business tax rate from 35 percent to 15 percent, and eliminate the corporate alternative minimum tax. This rate is available to all businesses, both small and large, that want to retain the profits within the business"12. He speaks of creating "the lowest tax rates since before World War II" (Trump 2015a, 153). No "business of any size will pay [...] more than 15 percent of their business income in taxes" (Trump 2015a, 153). There will "be only four [tax] brackets: $0 \%, 10 \%, 20 \%$, and $25 \%$ " (153). What one must note in this context is that when Trump came to power in 2016, the highest tax bracket was $39.6 \%$ for single filers' incomes over US\$ 415,050.

Trump expects that a low level of corporation tax will keep US companies from outsourcing jobs:

Our jobs are fleeing the country. They're going to Mexico. They're going to many other countries. You look at what China is doing to our country in terms of making our product. [...] So Ford is leaving. You see that, their small car divi-

\footnotetext{
${ }^{12}$ https://www.donaldjtrump.com/policies/tax-plan/
} 
sion leaving. Thousands of jobs leaving Michigan, leaving Ohio. [...] But we have to stop our jobs from being stolen from us. We have to stop our companies from leaving the United States and, with it, firing all of their people. All you have to do is take a look at Carrier air conditioning in Indianapolis. They left fired 1,400 people. They're going to Mexico. So many hundreds and hundreds of companies are doing this. We cannot let it happen. Under my plan, I'll be reducing taxes tremendously, from 35 percent to 15 percent for companies, small and big businesses. That's going to be a job creator like we haven't seen since Ronald Reagan. It's going to be a beautiful thing to watch. Companies will come. [...] I'm going to cut regulations. I'm going to cut taxes big league, and you're going to raise taxes big league, end of story" (Clinton and Trump 2016a).

Trump furthermore announced that American companies that outsource production to Mexico and other countries, but bring their products back to the USA in order to sell, them will face tariffs of 35\%: "Companies, like Carrier are firing their workers and moving to Mexico. Ford is moving all of its small car production to Mexico. When I'm President, if companies want to fire their workers and leave for Mexico, then we will charge them a $35 \%$ tax when they want to ship their products back into the United States. That means the companies won't leave in the first place and, if they do, we'll at least make money when they ship their products across the border"13. Such a measure is a clear state intervention into the free market. The purpose of this idea is, as we shall see, not to guarantee decent wages, but profitability within the USA. Trump believes in a national capitalism, in which US companies produce commodities in the US by exploiting US workers and export to other countries. Trump's version of national capitalism is not predominantly based on capital export and finance, but on construction, manufacturing, real estate and oil.

The logic that jobs are being stolen blames countries such as Mexico and China for capitalism's structural problems. Companies act driven by the imperative of profitmaximisation and the logic of competition. They will therefore tend to seek every opportunity to maximise profits. If outsourcing to another country is possible and poses the opportunity to increase profits, then there will be a tendency for companies seeking this opportunity. The problem arises from the combination of capitalism's structural logic of accumulation and the competition state. Competition with low-wage economies can easily result in vicious downward spirals of wage dumping and precarious working conditions.

Tax cuts for corporations tend to reduce the federal budget. Such reductions tend to hit the poorest if they are offset by cuts of public services. A secure way of how to stop outsourcing is to transform companies into worker-owned co-operatives. In such companies, the workers are the collective owner and take all decisions together. This structure advances a company interest that makes workers' interests the core of the company interest. Bernie Sanders argues for "new economic models" that provide support for the creation of worker-owned businesses. "Unlike large corporations that have been shipping jobs overseas, employee-owned businesses, by and large, are not shutting down and moving their businesses [...] employee-owned businesses boost morale, because workers share in profits and have more control over their work lives. The employees are not simply cogs in a machine owned by somebody else.

\footnotetext{
${ }^{13}$ https://www.donaldjtrump.com/press-releases/donald-j.-trump-proposes-american-deskprotect-economic-and-national-intere
} 
They have a say in how the company is run" (Sanders 2016b, 260-261). The Tax Policy Institute analysed Trump's revised tax plans and concluded:

The top quintile - or fifth of the distribution - would receive an average tax cut of $\$ 16,660$ (a 6.6 percent increase in after-tax income), the top 1 percent an average tax cut nearly 13 times larger $(\$ 214,690$, or 13.5 percent of after-tax income), and the top 0.1 percent an average tax cut approaching $\$ 1.1$ million (14.2 percent of after-tax income). In contrast, the average tax cut for the lowest-income households would be $\$ 110,0.8$ percent of after-tax income. Middleincome households would receive an average tax cut of $\$ 1,010$, or 1.8 percent of after-tax income (Nunns et al. 2016, 9).

So according to these calculations, the wealthy will be better off from these tax cuts and inequality will increase. The Tax Policy Institute also argues that as a result of Trump's plans of lowering income and business taxes, "the federal debt would increase by at least $\$ 7.0$ trillion over ten years" (Nunns et al. 2016, 1). The plans would "substantially increase budget deficits unless offset by spending cuts 16" (9). And if there were spending cuts and privatisations in realms such as education, social security and health care, then lower income groups would be hit hardest because they cannot easily afford private services.

Carrier is a US company that produces air conditioning-, ventilation- and heatingsystems. It planed to outsource of up to 2,000 manufacturing jobs from Indianapolis to Mexico. Trump had conversations with the company's management that as a result announced that it would only outsource parts of the jobs to Mexico: "We have negotiated an agreement with the incoming administration that we believe benefits our workers, the state of Indiana and our company. We are announcing today that Carrier will continue to manufacture gas furnaces in Indianapolis, in addition to retaining engineering and headquarters staff, preserving more than 1,000 jobs. [...] Today's announcement is possible because the incoming Trump-Pence administration has emphasized to us its commitment to support the business community and create an improved, more competitive U.S. business climate. The incentives offered by the state were an important consideration"14.

Bernie Sanders (2016a) commented:

It is not good enough to save some of these jobs. Trump made a promise that he would save all of these jobs, and we cannot rest until an ironclad contract is signed to ensure that all of these workers are able to continue working in Indiana without having their pay or benefits slashed. In exchange for allowing United Technologies to continue to offshore more than 1,000 jobs, Trump will reportedly give the company tax and regulatory favors that the corporation has sought. Just a short few months ago, Trump was pledging to force United Technologies to 'pay a damn tax.' He was insisting on very steep tariffs for companies like Carrier that left the United States and wanted to sell their foreign-made products back in the United States. Instead of a damn tax, the company will be rewarded with a damn tax cut. Wow! How's that for standing up to corporate greed? How's that for punishing corporations that shut down in the United States and move abroad? In essence, United Technologies took Trump

\footnotetext{
${ }^{14}$ https://www.carrier.com/carrier/en/us/news/newsarticle/carrier_statement_regarding_indianapolis_operations.aspx
} 
hostage and won. And that should send a shock wave of fear through all workers across the country".

On November 30, 2016, Trump announced the appointment of Goldman Sachs banker Steven Mnuchin as Treasury Secretary. Mnuchin was active in the motion picture industry (RatPac Entertainment), hedge funds, and banking. He was involved in purchasing the mortgage corporation IndyMac that went bankrupt during the 2008 economic crisis and offered high-risk mortgages. It was turned into the OneWest bank. Mnuchin announced the "largest tax change since Reagan" and said that "we are going to cut corporate taxes. [...] We are gonna get to 15 percent" (Jopson, Murphy and Sevastopolu 2016).

Trump also announced picking Wilbur Ross as Secretary of Commerce. In 2016, Ross was the $232^{\text {nd }}$ richest American. He had an estimated wealth of around US $\$ 2.9$ billion ${ }^{15}$. Ross is an investor who restructured companies in industries such as steel, coal, and textiles and invested into oil, gas, shipping, and transportation (Levine 2016). The underlying rationale may be that Ross is an expert in industries that Trump sees as forming key economic sectors. At the same time it is clear that Ross is close to the financial interests of these industries. Commenting on Trumponomics, Ross argues: "America in general would be good because it isn't just trade that Trump is gonna fix, it's the corporate tax. Reducing the corporate tax rate from 35 percent to 15, means that given the amount of pre-tax earnings will throw off 30 percent more after tax" (Levine 2016).

The examples of Mnuchin and Ross show how Trump brings representatives of the corporate class, who support hyper-capitalist politics, into key political positions. They support policies that favour the rich and corporations and will further advance the tendency that corporations pay little in taxes.

\subsubsection{Education}

Donald Trump appointed Betsy DeVos as education secretary. She comes from a billionaire family that owns Amway, a company that sells beauty and health products. Her husband Richard DeVos was in 2016 with an estimated wealth of US\$ 5.4 billion the $88^{\text {th }}$ richest American ${ }^{16}$ and the world's $308^{\text {th }}$ richest person ${ }^{17}$. According to news sources, Betsy DeVos "has long supported using taxpayer funds for voucher programmes, parochial schools and charters, all of which undermine and replace public schools and locally-elected school boards" (Lazare 2016).

DeVos describes her involvement in educational reform the following way: "Today there are about 250,000 students in 33 publicly funded, private-choice programs in 17 states and the District of Columbia. The movement's growth is accelerating. [...] We think of the educational choice movement as involving many parts: vouchers and tax credits, certainly, but also virtual schools, magnet schools, homeschooling, and charter schools" “18.

DeVos is the chairman of the American Federation for Children, whose task involves advancing private schools: "The American Federation for Children envisions

\footnotetext{
${ }^{15} \mathrm{http} / / /$ www.forbes.com/forbes-400/list/\#version:static search:wilbur\%20ro

$16 \mathrm{http}: / / w w w . f o r b e s . c o m / f o r b e s-400 / l i s t / \# v e r s i o n: s t a t i c$, accessed on November 28, 2016.

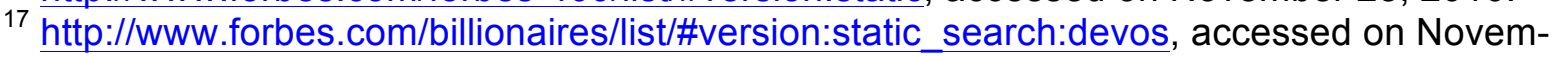
ber 28, 2016.

18
}

http://www.philanthropyroundtable.org/topic/excellence in philanthropy/interview_with_betsy devos 
an education system where parents are empowered to choose the best educational environment for their child, where innovation and entrepreneurism revolutionizes our education system, ensuring all children, especially low-income children, are provided with the opportunity to receive the finest education possible, whether it be in a traditional public school, public charter school, virtual learning, private school, home school or blended learning “19. Trump's campaign supported this kind of policies and promised to "add an additional federal investment of $\$ 20$ billion towards school choice. This will be done by reprioritizing existing federal dollars" 20 .

What could be the consequences of such policies? The National Education Association's President Lily Eskelsen García commented on DeVos's appointment: Her "efforts over the years have done more to undermine public education than support students. She has lobbied for failed schemes, like vouchers - which take away funding and local control from our public schools - to fund private schools at taxpayers' expense. These schemes do nothing to help our most-vulnerable students while they ignore or exacerbate glaring opportunity gaps. She has consistently pushed a corporate agenda to privatize, de-professionalize and impose cookie-cutter solutions to public education. By nominating Betsy DeVos, the Trump administration has demonstrated just how out of touch it is with what works best for students, parents, educators and communities“21.

\subsubsection{From Millionaire Politics to Billionaire Politics}

Most US presidents were certainly wealthy. Barack Obama's wealth was estimated to be US $\$ 12.2$ million in $2016^{22}$. The estimation of Bill Clinton's wealth was US $\$ 80$ million in $2016^{23}$. George W. Bush's wealth was according to estimations US\$ 35 million in $2016^{24}$. Barack Obama's 2014 and 2015 public financial disclosure reports ${ }^{25}$ show that he owned no significant shares in companies, but had income from pension investments and book royalties. Hillary Clinton's 2015 financial disclosure report ${ }^{26}$ shows just like the ones by her husband Bill that they both earn significant income from speaking fees. According to estimations, Bill Clinton earned more than US\$ 100 million from talks he gave in the year from 2001 until $2013^{27}$. Bernie Sanders criticised that Hillary Clinton for example received US\$225,000 for a talk she gave in 2013 at a Goldman Sachs conference. He said that finance capitalism "brought this country into the worst economic downturn since the Great Recession, the Great Depression of the 30s, when millions of people lost their jobs, their homes and their life savings. The obvious response to that is that you have got a bunch of fraudulent operators and that they have got to be broken up. [...] Now Secretary Clinton was busy giving speeches to Goldman Sachs for 225,000 dollars a speech" (Grif-

\footnotetext{
${ }^{19} \mathrm{http}: / /$ www.federationforchildren.org/about-us/mission/

20 https://www.donaldjtrump.com/policies/education/

21 http://www.nea.org/home/69329.htm

22 http://www.therichest.com/celebnetworth/politician/president/barack-obama-net-worth/

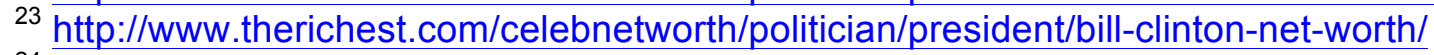

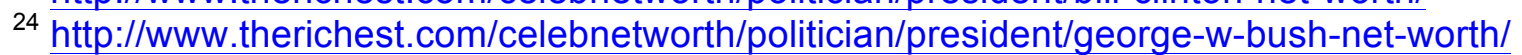

25 https://www.whitehouse.gov/sites/default/files/docs/oge_278_cy_2014_obama.pdf, https://www.whitehouse.gov/sites/whitehouse.gov/files/documents/oge_278_cy_2015_obam a 051616.pdf

${ }^{26}$ https://assets.documentcloud.org/documents/2082788/hillary-clinton-financial-disclosureform.pdf, http://pfds.opensecrets.org/N00000019_2015_Pres_A.pdf, http://pfds.opensecrets.org/N00000019_2015_Pres.pdf

${ }^{27}$ http://www.therichest.com/celebnetworth/politician/president/bill-clinton-net-worth/
} 
fin, Fitzpatrick and Devine 2016). Whereas Hillary and Bill Clinton interlock with corporate elites via talks they give, which means that they provide a service for relatively high fees, Donald Trump's interlocking is of a different nature and involves ownership shares.

George W. Bush was US president from 2001 to 2009. In the 1970s and 1980s, he was involved in the oil business as part of the companies Arbusto Energy, Bush Exploration, Spectrum 7, and HKN Inc. His 1999/2000 financial disclosure-report ${ }^{28}$ shows that Bush earned income from savings and real estate investments and capital gains from the ownership of the Texas Rangers baseball team. A group around Bush owned the Texas Rangers from 1989 until 1998. His real estate and financial income included the George W. Bush Qualified Diversified Trust and ownership of 1583 acres in McLennan County in Texas. Both assets had a value of over US\$ 1 million. In 1978, Bush was an unsuccessful candidate for the House of Representatives. He was involved in his father's presidential campaigns in the late 1980s and early 1990s. So although having had connections to politics, Bush did not enter politics fully before 1995 when he became Texas's governor. Bush was just like Trump a capitalist-turned politician. The difference is that Bush came from a Republican family involved in both the oil business and politics. Donald Trump was a businessman all his life and turned very late towards politics. He became US president at the age of 70 and is therefore the oldest president in US history. Another important difference between Bush and Trump is that Bush is certainly rich, but Trump is super-rich and is part of the elite of the world's richest people. According to his 2016 financial disclosure statement, Trump was before the election involved in at least 500 companies $^{29}$. According to estimations ${ }^{30}$, Trump's wealth was in 2016 more than 128 times as large as Bush's. High quantity can turn into a different quality, which means that the amount of Trump's connections and economic power may trigger a qualitative transformation of the US state.

Donald Trump is a billionaire, whose status as president and as well-connected billionaire results in a structure of the US state, where capitalist and state interests directly interlock and overlap. Traditionally this interlocking was more indirect. Trump is a billionaire-turned-president, who has lots of connections to many different capitalist industries. The interlocking of the state and capital and Trump's representation of the interests of big capital can be observed in suggestions that aim at advance a lowtax-economy that benefits big capital and state intervention that favours capital interests in industries such as private education, private health care, the pharmaceutical industry, the oil, gas and coal industry, the construction industry, and the transport industry.

On November 30, 2016, Donald Trump announced on Twitter that he "will be leaving" his "business in total in order to fully focus on running the country" and that "legal documents are being crafted which take me completely out of business operations" ${ }^{31}$. On January 11, 2017, Trump gave a news conference, in which he announced that his business would be conveyed to a trust and that his sons Donald Jr. and Eric would take over the Trump Organization's management. He said that we would not

\footnotetext{
${ }^{28}$ http://news.findlaw.com/hdocs/docs/gwbush/gwbush-sf278.pdf

${ }^{29} \mathrm{http}: / /$ pfds.opensecrets.org/N00023864_2016_Pres.pdf

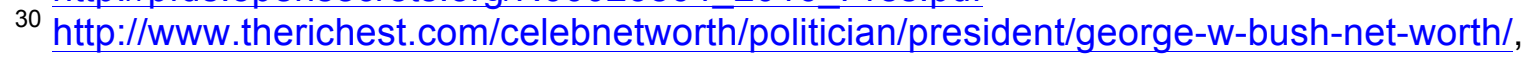
http://www.forbes.com/forbes-400/list, accessed on November 27, 2016.

${ }^{31}$ https://twitter.com/realDonaldTrump/status/803926488579973120,

https://twitter.com/realDonaldTrump/status/803926488579973120,

https://twitter.com/realDonaldTrump/status/803931490514075648
} 
take any influence on business operations during his presidency. An ethics adviser would vet national deals made by the Trump Organization for potential conflicts of interest. No international deals would be made. It is important to stress that Trump did not sell the Trump Organization and did not divest, which would have been a way towards eliminating possible conflicts of interest. "Trump's commitment falls short of the recommendations from the Office of Government Ethics and former chief White House ethics advisors for both parties, who say the only way for Trump to fully inoculate himself from conflicts is to fully divest his business holdings and clearly break from financial interests" (Harwell 2017).

Observers commented that these changes "fell short of the recommendations of ethics experts in both parties who have said the only way for Mr. Trump to genuinely eliminate potential conflicts is to place all his real estate holdings and other business ventures in a blind trust over which neither he nor his family has any control, severing him entirely from the enterprise. [...] Mr. Trump's influence over foreign and domestic policy as president has raised questions about whether American policy could affect his bottom line. For instance, he will oversee the regulation of banks, some of which lend money to his company, and he will have frequent contact with foreign heads of state, including some who run countries where he does business" (Haberman, Hirschfeld Davis and Lipton 2017).

Although there is not a direct simultaneous double role of Trump as businessman and president, his decades-long business practices certainly bring a capitalist interest to the office that he cannot easily leave behind. "The emphasis on 'business operations', not on ownership, hinted that Mr. Trump is not ruling out retaining a financial stake in the Trump Organization or putting his children in control of the company. Ethics experts said such moves would leave Mr. Trump vulnerable to accusations that his official actions are motivated by personal financial interests" (Shear and Lipton 2016).

\subsubsection{The State and Capitalism in Other Parts of the World}

The changing relationship between the state and capitalism is an important dimension in the analysis of Trump. State capitalism in the case of Trump means that to a certain degree the state and capitalism intersect in the form of capitalist-turnedpoliticians such as Donald Trump, Rex Tillerson, Andrew F. Puzder, Steven Mnuchin, Wilbur Ross, or Betsy DeVos.

When talking about state capitalism, one should not forget that although Europe and North America dominate world trade and capital export, their companies and states are not the only economic and political actors in the world system. Kurlantzick (2016) argues in his book State Capitalism: How the Return of Statism is Transforming the World that over the past two decades, state-capitalist economies have grown. He defines state capitalism as a political economy, in which the state exerts significant influence over at least one-third of the 500 biggest companies and the state directly intervenes to a significant degree into the management of the economy (Kurlantzick 2016, 9). He argues that state-capitalism exists for example in China, Brazil, India, Russia, Indonesia, Saudi Arabia, Argentina, Norway, Iran, Thailand, the United Arab Emirates, Malaysia, Singapore, Egypt, Kazakhstan, Algeria, Qatar, Venezuela, Vietnam, and Kuwait. Kurlantzick argues that state capitalism can be accompanied by different political systems, ranging from liberal democracy to authoritarianism.

China would be the most striking example of state capitalism. Only three of the fortytwo of the largest Chinese companies are privately owned (4). The role of the Chinese state would not just involve tight political control of the country, but also an im- 
portant role of state-owned enterprises, and the state intervening into and putting limits on financial markets during the 2015/2016 stock market's crisis. Public investments into city infrastructure form another element of Chinese state capitalism. China also subsidised some of its exports and by state-regulation established exportprocessing zones, in which foreign capital has access to cheap labour. However, one needs to take into account that according to statistics, capitalist ownership dominates the Chinese economy (see Fuchs 2015, chapter 7). According to official statistics, in 2015 state-owned and collective enterprises accounted for $12.3 \%$ of industrial profits, share-holding companies for $46.0 \%$, private enterprises for $24.9 \%$, and foreign investors' companies for $16.8 \%$ (National Bureau of Statistics of China 2016). One of the problems of Kurlantzick's book is that he opposes the United States to state capitalism. He argues that the US could save the world from state capitalism's negative impacts. With the rise of Donald Trump, one however cannot rule out that US society will take on certain elements of state capitalism.

\subsection{The Relationship of the State to its Citizens: Civil Liberties and State Insti- tutions under Trump}

\subsubsection{Authoritarian Statism}

Contemporary politics is shaped by authoritarian populists such as Rodrigo Duterte (Philippines), Recep Tayyip Erdoğan, Nigel Farage (UK), Jarosław Kaczyński and Beata Szydlo (Poland), Marine Le Pen (France), Narendra Modi (India), Viktor Orbán (Hungary), Vlarimir Putin (Russia), Heinz Christian Strache (Austria), Geert Wilders (Netherlands). Donald Trump's presidency is the most powerful expression of the rise of right-wing populism. The key question in respect to state institutions and civil liberties is whether Trump's presidency may result in an authoritarian form of US capitalism. In the age of Trump, we should think about how to understand authoritarian capitalism.

Lenin $(1917,398)$ argues that a "democratic republic is the best possible political shell for capitalism". The problem of this assumption is that Nazi Germany shows that capitalism and democracy do not form a necessary unity. In contrast to fascist capitalism, the ground for opposition is much larger in liberal democracies. Bob Jessop $(2016,212)$ argues that under specific circumstances, authoritarian statism can become the best possible shell for capitalism.

State theorist Nicos Poulantzas argues that authoritarian statism transfers powers of legislation and the judiciary to the executive power of the president/prime minister. Authoritarian statism is a state form that features "intensified state control over every sphere of political democracy" and the "draconian and multiform curtailment of socalled 'formal' liberties" (Poulantzas 1980/2000, 203-2014). There is a decline of the rule of law, also evident in "the increasing concern for the pre-emptive policing of the potentially disloyal and deviant" (Jessop 1990, 67). There is an encouragement of "the fusion of the three branches of the state - legislature, executive and judiciary" (Jessop 1990, 67).

The Second World War was accompanied by the rise of a particular form of authoritarian state capitalism in Germany, namely Nazi fascism. Comparable to Kurlantzick (2016), also critical theorist Friedrich Pollock (1975) argues that state capitalism has two characteristic forms: democratic and totalitarian state capitalism. His analysis refers to Fordist capitalism. By totalitarian state capitalism, he primarily means Nazi Germany. Fascist societies have powerful states. The historian Tim Mason $(1995,53-76)$ therefore characterises Nazi Germany as a society, in which there 
was a primacy of politics over the economy. This means that companies had to support Hitler's regime if they wanted to survive. The state and capital formed a unity. Capitalism in Nazi Germany was based on combines and cartels that all used the leadership principle as organisational means (Neumann 2009, 233). The leadership principle was taken over from the Nazi-state into the economy. "The underlying [Nazi] ideology is racism, the sovereignty of the racial people incarnated in the Leader. The whole structure is at the service of two ideas, the New Order and proletarian racism" (Neumann 2009, 221). Cartels were formed by state power in the form of compulsory cartelisation (Neumann, Marcuse and Kirchheimer 2013, 270, 273-274).

Neumann (see 2009, 221-234) disagrees with Friedrich Pollock's view that during the Nazi time, there was totalitarian state capitalism in Germany. Pollock $(1941,445)$ writes that Hitler "transformed monopoly capitalism into state capitalism" (Pollock 1941, 445). Neumann in contrast suggests that Nazi-Germany's economy was "a monopolistic economy - and a command economy. It is a private capitalistic economy, regimented by the totalitarian state. We suggest as a name best to describe it, 'Totalitarian Monopoly Capitalism'” (Neumann 2009, 261). Neumann (2009, 116-120, 275 ) says that the "Aryanisation" of Jewish property played an important role in NaziGermany's monopoly capitalism. It helped to advance monopoly capital's interests. Examples were Otto Wolff AG (steel), Friedrich Flick's conglomerate (steel, iron, coal), or Mannesmann (steel, iron) (275, 288-292). Nazi imperialism also involved the "Germanisation" of militarily conquered economies (275-277).

Neumann described proletarian racism as an aspect of fascist capitalism: "Racial proletarianism is the genuine theory of National Socialism and its most dangerous expression. [...] The essence of the theory is extremely simple. Germany and Italy are proletarian races, surrounded by a world of hostile plutocratic-capitalistic-Jewish democracies. [...] It exploits hatred of the Jews, aversion to capitalism, and, finally, utilizes Marxist phraseology and symbolism to an ever increasing extent. It is clear that the very purpose of the doctrine of racial proletarianism is to entice the working classes" (Neumann 2009, 188, 187, 188). Nazism had a short-circuited critique of capitalism that pitted industrial capital against finance capital. It biologised and racialised this difference.

\subsubsection{Is Trump A Fascist?}

Franz Neumann $(1957,244-245)$ argues that modern totalitarian dictatorship, or what he also terms the authoritarian state, consists of five elements:

1) A police state substitutes the rule of law. "The rule of law is a presumption on favour of the right of the citizen and against the coercive power of the state" (244);

2) The centralisation of political power;

3) The existence of a monopolistic state party;

4) Totalitarian social controls extent to all realms of society in the form of the leadership principle, the synchronisation of social organisation, the substitution of bureaucracies by private leadership groups, the destruction of social organisations that are substituted by undifferentiated mass organisations and atomise the individual, and the transformation of culture into propaganda;

5) The reliance on terror.

These elements relate to the relationship of the state to itself, the economy, and citi- 
zens/civil society.

Since the start of the crisis in 2008 , it has become evident that the contradiction between global capitalism and politics at the level of the nation state has implications at the level of subjectivity. There has been a backlash so that the contradiction has been sublated into the strengthening of authoritarian statism and authoritarian populist ideology. Bob Jessop argues in this context:

We should particularly note the continued decline of parliament and rule of law, the growing autonomy of the executive, the increased importance of presidential or prime ministerial powers, the consolidation of authoritarian, plebiscitary parties that largely represent the state to the popular masses, and - something neglected by Poulantzas - the mediatization of politics as the mass media play an increasing role in shaping political imaginaries, programmes, and debates. A stronger emphasis on issues of national security and pre-emptive policing associated with the so-called war on terror at home and abroad has reinforced the attack on human rights and civil liberties (Jessop 2016, 245-246).

One cannot rule out that in the times we live in, states of emergency and exception are declared by ruling right-wing governments. "States of emergency are declared, commissarial dictatorships are appointed, or (quasi-)sovereign dictatorships seize power in response to threats to the state" (Jessop 2016, 218). This can involve the suspension of elections, the centralisation and monopolisation of power (ban and limitation of the political opposition), the concentration of state powers (legislative power, executive power, judiciary power), the suspension of the rule of law, the use of repressive state apparatuses against political opponents (control, surveillance, policing, law and order politics, police killings, secret services' covert operations, militarisation, war etc.) and an ideological offensive that includes real and ideological violence against foreigners, immigrants, migrants, people of colour, and other minorities.

Influenced by Franz Neumann's works, Robert O. Paxton $(2004,218)$ defines fascism as "a form of political behavior marked by obsessive preoccupation with community decline, humiliation, or victimhood and by compensatory cults of unity, energy, and purity, in which a mass-based party of committed nationalist militants, working in uneasy but effective collaboration with traditional elites, abandons democratic liberties and pursues with redemptive violence and without ethical or legal restraints goals of internal cleansing and external expansion". Elements of fascism are a sense of crisis, nationalism, ideological discourse of the national community as victim and being under decline, victimization discourse, exclusionary violence, authoritarianism and leadership ideology, Darwinian struggle, and the suspension of the rule of law (219-220). This is certainly a comprehensive definition. It however lacks any focus on the economy. For Neumann, fascism was the combination of a repressive, racist and terrorist political system, racist monopoly capitalism, and the ideologies of leadership, nationalism and proletarian racism.

Paxton (2016) argues that Donald Trump means "self-indulgent demagoguery on behalf of oligarchy":

Superficially, he seems to have borrowed a number of fascist themes for his presidential campaign: xenophobia, racial prejudice, fear of national weakness and decline, aggressiveness in foreign policy, a readiness to suspend the rule of law to deal with supposed emergencies. His hectoring tone, mastery of crowds, and the skill with which he uses the latest communications technologies 
also are reminiscent of Mussolini and Hitler. And yet these qualities are at most derivative of fascist themes and styles; the underlying ideological substance is very different, with the entitlements of wealth playing a greater role than fascist regimes generally tolerated. Trump's embrace of these themes and styles is most likely a matter of tactical expediency - a decision taken with little or no thought about their ugly history. Trump is evidently altogether insensitive to the echoes his words and oratorical style evoke, which should not be surprising, given his apparent insensitivity to the impact of every other insult that he hurls.

Given that Paxton leaves out the economic dimension in his definition of fascism, it is no wonder that his stress on oligarchy in his assessment of Trump plays a role in the conclusion he draws. One cannot rule out that elements of extreme authoritarianism will emerge under Donald Trump's presidency. It could be the case or it could not be the case. Trump is quite unpredictable and it is not for sure to which extent he puts into action and radicalises what he said during his election campaign. The decisive questions will be whether his policies will advance the interests of US monopoly capital, limit civil liberty, limit or repress democratic opposition, advance racism, nationalist division and violence against minorities, militarise the country, and engage in imperialist war.

Roger Griffin takes an approach on Trump that is comparable to the one by Paxton. Griffin $(1993,44)$ defines fascism as

a genus of political ideology whose mythic core in its various permutations a palingenetic form of populist ultra-nationalism. The fascist mentality is characterized by the sense of living through an imminent turning-point in contemporary history, when the dominance of the allegedly bankrupt or degenerate forces of conservatism, individualistic liberalism and materialist socialism is finally to give way to a new era in which vitalistic nationalism will triumph. To combat these rival political ideologies and the decadence they allegedly host (for example the parasitism of traditional elites, materialism, class conflict, military weakness, loss of racial vitality, moral anarchy, cosmopolitanism), fascist activists see the recourse to organized violence as both necessary and healthy. Though they may well make some concessions to parliamentary democracy in order to gain power, the pluralism of opinion and party politics upon which it rests is anathema to their concept of national unity, which implies in practice the maximum totalitarian control over all areas of social, economic, political and cultural life.

Based on this understanding, Griffin argues that Trump is not a fascist: "You can be a total xenophobic racist male chauvinist bastard and still not be a fascist. [...] As long as Trump does not advocate the abolition of America's democratic institutions, and their replacement by some sort of post-liberal new order, he's not technically a fascist" (Cited in: Matthews 2016).

Noam Chomsky takes an approach that differs from Paxton and Griffin. Chomsky argues that Trump is unpredictable and that one therefore cannot tell whether he will advance authoritarian statism and/or a "me"-ideology that aims at increasing his popularity:

For many years, I have been writing and speaking about the danger of the rise of an honest and charismatic ideologue in the United States, someone who could exploit the fear and anger that has long been boiling in much of the socie- 
ty, and who could direct it away from the actual agents of malaise to vulnerable targets. That could indeed lead to what sociologist Bertram Gross called 'friendly fascism' in a perceptive study 35 years ago. But that requires an honest ideologue, a Hitler type, not someone whose only detectable ideology is Me. The dangers, however, have been real for many years, perhaps even more so in the light of the forces that Trump has unleashed (Chomsky 2016).

Historian Robert Kagan (2016) argues that Trump has commonalities with fascist leaders:

His incoherent and contradictory utterances have one thing in common: They provoke and play on feelings of resentment and disdain, intermingled with bits of fear, hatred and anger. His public discourse consists of attacking or ridiculing a wide range of "others" - Muslims, Hispanics, women, Chinese, Mexicans, Europeans, Arabs, immigrants, refugees - whom he depicts either as threats or as objects of derision. His program, such as it is, consists chiefly of promises to get tough with foreigners and people of nonwhite complexion. He will deport them, bar them, get them to knuckle under, make them pay up or make them shut up. [...] [Fascist movements] play on all the fears, vanities, ambitions and insecurities that make up the human psyche. In democracies, at least for politicians, the only thing that matters is what the voters say they want - vox populi vox Dei. A mass political movement is thus a powerful and, to those who would oppose it, frightening weapon. When controlled and directed by a single leader, it can be aimed at whomever the leader chooses. [...] He might be the highest-ranking elected guardian of the party's most cherished principles. But if he hesitates to support the leader, he faces political death.

It is too early to tell whether or not there will be tendencies of Trump's rule that advance authoritarian statism in US capitalism. The decisive criteria for judging to which extent this development will occur are whether one will observe the decline of the rule of law, the concentration of power and the limitation of political opposition in order to enforce policies that support the capitalist class, the leadership principle and leadership ideology, nationalism combined with the friend/enemy scheme and victimisation discourses.

\subsubsection{Law \& Order Politics}

Trump stands for law and order politics:

And we need law and order. If we don't have it, we're not going to have a country. [...] We have to bring back law and order. Now, whether or not in a place like Chicago you do stop and frisk, which worked very well [...] We have gangs roaming the street. And in many cases, they're illegally here, illegal immigrants. And they have guns. And they shoot people. And we have to be very strong. And we have to be very vigilant (Clinton and Trump 2016a).

\subsubsection{Opponents}

In 2006, Donald Trump said about comedian Rosie O'Donnell, who had criticised him: "If you take a look at her, she's a slob. How does she even get on television? If I were running The View, l'd fire Rosie. I'd look her right in that fat, ugly face of hers and say, 'Rosie, you're fired'“ (Oppenheim 2016). Other comments he made about 
her include the following ones: "She came to my wedding. She ate like a pig. And - I mean, seriously, the wedding cake was - was - it was like missing in action. I couldn't stand there" (Zaru 2016). "She is an unattractive person both inside and out" (Trump and Zanker 2008, 187-188). "I think I can cure her depression. If she'd stop looking in the mirror I think she'd stop being so depressed" (Trump and Zanker 2008, 189). "I hit that horrible woman right smack in the middle of the eyes" (Trump and Zanker 2008, 190). In the 2016 presidential election, Trump defended these comments: "[S]omebody who's been very vicious to me, Rosie O'Donnell, I said very tough things to her, and I think everybody would agree that she deserves it and nobody feels sorry for her" (Clinton and Trump 2016a).

In his book Think Big: Make It Happen In Business and Life, Trump writes: "When somebody screws you, screw them back in spades. [...] When someone attacks you publicly, always strike back. [...] Go for the jugular so that people watching will not want to mess with you" (Trump and Zanker 2008, 199).

Democratic politics involves opposition. Opposition not just means disagreement, but also public disagreement, in which not always only nice words are used. If, however, the logic of retaliation is used in politics by someone coming to power and if somebody in this position hits back in spades and goes for the opponents' jugulars, then actual dangers for democracy can arise.

Donald Trump repeatedly made highly problematic comments about women and others. In a leaked videotape recorded in 2005, he says: "You know I'm automatically attracted to beautiful - I just start kissing them. It's like a magnet. Just kiss. I don't even wait. And whey you're a star they let you do it. You can do anything. Grab them by the pussy. You can do anything" ${ }^{\text {"2 }}$. Also information about other alleged problematic comments and behaviour has been published (see e.g. Kranish and Fisher 2016, 55-57, 63-69, 88-91, 109, 150, 163-165, 167, 217, 257-258, 278-279).

The question that arises is what the implications are when a personality, who does not always treat others with respect, becomes US president. The question is what could happen in world politics if such a person feels highly provoked by other international politicians and what reactions would follow. Only political history will tell.

Donald Trump has at different times expressed different opinions on the question whether he wants to have a special prosecutor who looks into Hillary Clinton's e-mail affair. The danger is that the appointment of such a special prosecutor could very well be interpreted as a form of political revanchism directed against a political opponent.

In the second television debate with Clinton, Trump said:

If I win, I am going to instruct my attorney general to get a special prosecutor to look into your situation, because there has never been so many lies, so much deception. There has never been anything like it, and we're going to have a special prosecutor. [...] The people of this country are furious. [...] There has never been anything like this where e-mails... And you get a subpoena. You get a subpoena, and after getting the subpoena, you delete 33,000 e-mails. And then you acid-wash them or bleach them, as you would say. [...]

Clinton: It is just awfully good that someone with the temperament of Donald Trump is not in charge of the law in our country.

Trump: Because you'd be in jail! (Clinton and Trump 2016b).

${ }^{32}$ https://www.youtube.com/watch?v=C-Rr7CO59HY 
After the election, Trump came back to this issue in an interview with the New York Times" "Trump: I want to move forward, I don't want to move back. And I don't want to hurt the Clintons. I really don't. She went through a lot. And suffered greatly in many different ways. And I am not looking to hurt them at all. The campaign was vicious. They say it was the most vicious primary and the most vicious campaign. [...] Deptuty Managing Editor: So you're definitively taking that off the table? The investigation? [...] Trump: No, no, but it's just not something that I feel very strongly about" (Trump 2016b).

In 2006, Donald Trump bought land in Balmedie, a village near Aberdeen in Scotland, in order to build a golf course and a hotel. This Trump estate is described in the following words on its website: "This opulent five-star property provides exquisite superior and deluxe guestrooms, intimate bar and dining facilities [...] MacLeod House \& Lodge offers luxury and comfort in a secluded and dramatic location. [...] MacLeod House \& Lodge is ideally situated for visitors, business travellers and golfers" ${ }^{33}$. "The golf course follows a classic pattern of two out-and-back loops of nine holes. All 18 holes thread their way engagingly through the dunes, rising here to find views of the sea and the coastline, plunging there into secluded valleys, offering a sequence of superlative topographies, landscapes, alternating between spaciousness and enclosure, then panoramic view, and the whole time a rich texture of vegetation and wildlife habitats surrounding the golf holes"34.

Anthony Baxter's (2011) documentary You've Been Trumped paints a less idyllic picture and shows the conflicts between Trump and Balmedie residents. Some local residents, including the farmer Michael Forbes, refused to sell their land to Trump. Donald Trump in an interview shown in the movie, said about Forbes: "His property is terribly maintained. It's slum-like. It's disgusting. [...] He lives like a pig" (Baxter 2011). The documentary shows how the residents, who stayed, faced problems with their new neighbour. A public statement by Trump says that Forbes "has always been dirty, sloppy and unkempt in his personal appearance and demeanor. He is a loser who is seriously damaging the image of both Aberdeenshire and his great country. [...] His property is a disgusting blight on the community and an environmental hazard, with leaking oil containers, rusted shacks and abandoned vehicles dumped everywhere. It is a very poor image and representation for the world to see of Scotland" (Carrell 2016).

"Trump claimed in 2008 that his planned resort would employ 1,200 people; it currently employs 95, many of whom will be seasonal. [...] Despite the bitter opposition of all Scotland's environment agencies and charities, Scottish government ministers, who were backed by local business and council leaders, decided the scheme was of national importance. In November 2008 they ruled that this allowed Trump to bulldoze through a third of the Foveran dunes complex, a legally protected site of special scientific interest (SSSI), and breach the council's structural plans, which defined Menie as green belt land" (Carrell 2016). The example shows how Trump in this case resorted to personal abuse of an economic opponent, who had different interests than the billionaire businessman.

33

http://www.trumpgolfscotland.com/Default.aspx?p=dynamicmodule\&pageid=100030\&ssid=1 $00047 \& v n f=1$, accessed on November 30, 2016.

34

http://www.trumpgolfscotland.com/Default.aspx?p=dynamicmodule\&pageid=100012\&ssid=1 $00034 \& v n f=1$, accessed on November 30, 2016. 


\subsubsection{Breitbart}

Trump appointed Stephen Bannon as chief White House strategist. Bannon was a founding member and executive chair of Breitbart, a far-right news blog. In late 2016, Breitbart was the $671^{\text {st }}$ most accessed web site in the world and the $127^{\text {th }}$ most accessed platform in the USA ${ }^{35}$. It attracts more online readers than for example Bloomberg, the New York Post, ABC News, Slate, CNBC, Time Magazine, Mashable, NYDailyNews, BBC, Reuters, CBS, TheDailyBeast, The Atlantic, CBS Local, and the New Yorker. Breitbart's US readership increased from 7.4 million in September 2014 to 15.8 million in September 2016 (Booth et al. 2016).

Bannon called Occupy activists shown in a movie he made the "greasiest, dirtiest people you will ever see" (cited in: Friedersdorf 2016). Commenting on Black Lives Matter and police shootings of black Americans, Bannon said: "What if the people getting shot by the cops did things to deserve it? There are, after all, in this world, some people who are naturally aggressive and violent"36.

One gets an impression of the world according to Breitbart by having a look at the type of articles it publishes and how it portrays society in them:

- An article by David Horowitz called the conservative commentator William a "renegade Jew" ${ }^{37}$ for being critical of Donald Trump.

- One article had the title "Birth Control Makes Women Unattrative and Crazy"38,

- Abortion was compared to the Holocaust: "Planned Parenthood can attribute a good portion of their boffo baby-killing business to their president since 2006, Cecile Richards. Richards is well on her way to personally matching Hitler's body count. Breitbart has done the grim maths so you don't have to. Using a conservative estimate of 300,000 abortions a year - or 300 kiloscrapes, using the technical metric measure - Cecile Richards has presided over three million abortions, or three megascrapes in her ten years as president of the organisation. This has earned her 'half Holocaust' status. Full Holocaust seems eminently reachable given Planned Parenthood's growing hegemony in the abortion industry"39.

- On black Americans: "After 50 years of celebrating MLK's civil rights legacy, black people now commit a catastrophically high amount of crime. [...] So how is it then that there are five times fewer black people than white people in America and, yet, we consistently carry out a larger share of the crimes?" 40

- On white Americans: "Anti-White Racism: The Hate That Dares Not Speak Its Name [...] A principal source of the war on white people generally and law enforcement in particular is our leftwing university and literary culture, which for forty years has taught college students that it is politically correct to hate white people; which fosters a hatred of America so virulent, that it has inspired millennials to flock to a lifelong supporter of communist causes like Bernie Sanders and to avert

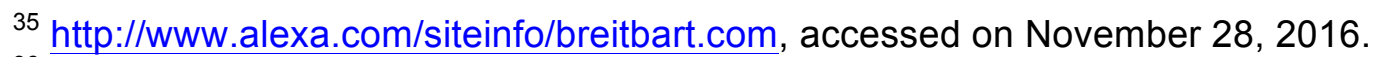

${ }^{36}$ http://www.breitbart.com/big-journalism/2016/07/10/sympathy-devils-plot-roger-ailesamerical

${ }^{37}$ http://www.breitbart.com/2016-presidential-race/2016/05/15/bill-kristol-republican-spoilerrenegade-jew/

${ }^{38}$ http://www.breitbart.com/tech/2015/12/08/birth-control-makes-women-unattractive-andcrazyl

${ }^{39}$ http://www.breitbart.com/big-government/2015/08/22/godwins-law-planned-parenthoodsbody-count-is-up-to-half-a-holocaust/

${ }^{40}$ http://www.breitbart.com/big-hollywood/2016/01/21/10-things-black-people-should-worryabout-that-arent-oscar-so-white/
} 
its own gaze from this impertinent fact: the largest, most oppressive and most violent inner cities in America are 100\% controlled by the Democratic Party - the party of slavery and segregation - and have been for fifty to a hundred years" ${ }^{\text {" } 41}$.

- On illegal immigrants: "If you think data about illegal alien crime is hidden from public, just try to find information on the contagious diseases brought across our borders by illegal aliens from nearly 100 countries. If we survey the anecdotal and sporadic official data of the past fifteen years, there is no doubt we are being invaded daily by dangerous diseases. There is good reason to believe the government is minimizing this risk as part of its disinformation campaign to sanitize illegal immigration and to portray all critics as 'anti-immigrant.' Although the U.S. Border Patrol publishes frequent reports on the number of individuals apprehended crossing the border, no agency publishes reports on the diseases they bring with them and then carry into our communities. [...] What should scare us most is not what we know about the health of 700,000 illegal aliens arriving each year but what we do not know. When the Obama administration goes to great lengths to hide the truth about so many of its activities, there is no reason to trust what they are telling us about the health profiles of hundreds of thousands of illegal aliens released into the American heartland. [...] If an illegal alien from Brazil or Vietnam and carry an infectious disease across the border by accident, what kind of diseases can be carried and spread by Islamic jihadis who are on a suicide mission? [...] The public health ramifications of our scandalous open borders are possibly even more dangerous and far-reaching than the economic and political consequences" ${ }^{2}$.

Such articles give an impression of the ideology and conspiracies that Breitbart advances, in which white America is under attack by illegal immigrants, Muslims, liberals, leftists, feminists, etc. Breitbart supports Donald Trump, who promised in his election campaign to "make America great again". Trump responded to the criticisms of Bannon and Breitbart: "I've known Steve Bannon a long time. If I thought he was a racist, or alt-right, or any of the things that we can, you know, the terms we can use, I wouldn't even think about hiring him. [...] Breitbart cover things, I mean like The New York Times covers things. [...] Breitbart, first of all, is just a publication. [...] Now, they are certainly a much more conservative paper, to put it mildly, than The New York Times. But Breitbart really is a news organization that's become quite successful" (Trump 2016b).

Mike Pence, Trump's vice-president, visited the Broadway musical "Hamilton" on November 18, 2016, ten days after Trump had been elected. Brandon Victor Dixon, one of the actors, addressed Pence on behalf of the crew, saying, "Vice Presidentelect Pence, we welcome you and we truly thank your for joining us here at Hamilton. We, sir, we are the diverse America who are alarmed and anxious that your new administration will not protect us, our planet, our children, our parents, or defend us and uphold our inalienable rights, sir. What we truly hope is that this show has inspired you to uphold our American values and to work on behalf of all of us"43.

Obviously, this message was an expression of concerns that Donald Trump's administration could limit diversity and impose discriminatory policies. Donald Trump

\footnotetext{
${ }^{41}$ http://www.breitbart.com/big-journalism/2016/04/26/anti-white-racism-hate-dares-notspeak-name-2/

${ }^{42}$ http://www.breitbart.com/big-government/2015/12/25/why-are-many-diseases-backdecades-after-being-wiped-out-in-the-u-s/

${ }^{43}$ https://www.thestar.com/entertainment/2016/11/19/mike-pence-sees-hamilton-gets-sharppersonalized-speech-from-cast.html, accessed on November 29, 2016.
} 
reacted to it in a tweet (see figure 5). It is interesting to see that Trump does not seem to see any problems about Breitbart, a publication that expresses intolerant views, but denunciates the Hamilton crew's call for tolerance in a message posted to his 16 million followers on Twitter.

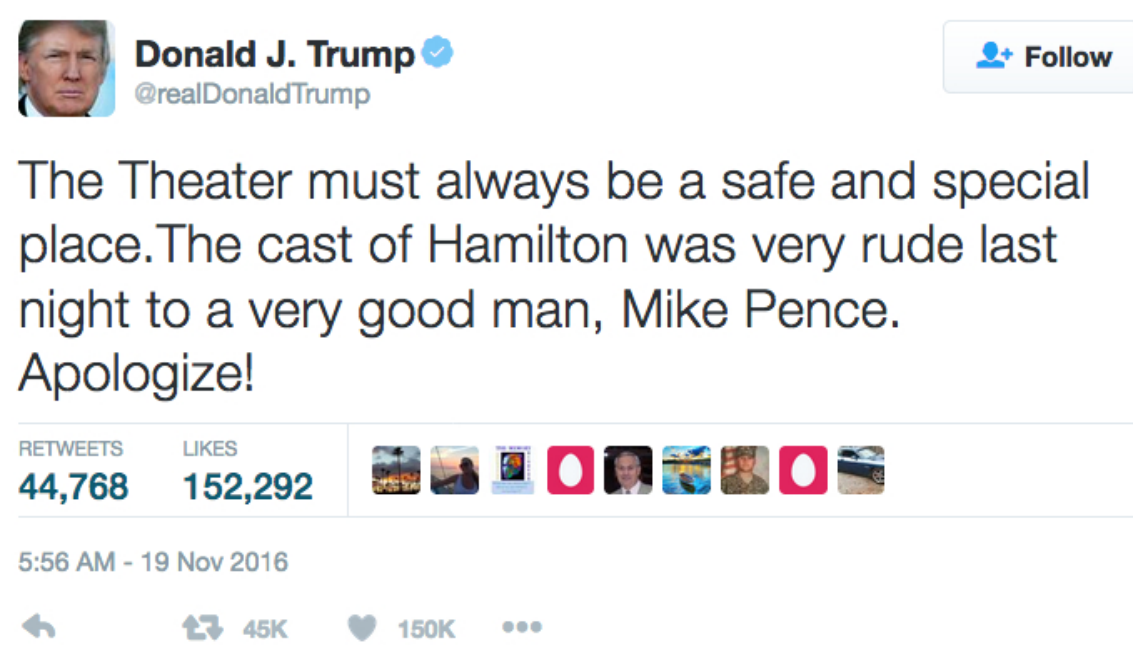

Figure 5: Donald Trump's reaction to the Hamilton crew's concerns about his presidency

\subsubsection{Immigration}

In 1979, Donald Trump bought the department store Bonwit Teller located at Sixth Avenue and $56^{\text {th }}$ Street in New York. He demolished the building in order to build the Trump Tower. Libby Handros (1991) argues in her documentary film Trump: What's the Deal? that for the demolition, William Kaszycki's company hired more than 200 Polish immigrants "with no working papers, who were paid one third the union rate and worked under difficult conditions" (Handros 1991, 31:41-31:47). One worker says in the documentary, "all the wires, lots of construction, it was covered with asbestos" (32:29-32:39). Kranish and Fisher $(2006,88)$ in their book Trump Revealed argue about the working conditions at the demolition site: "The men toiled through spring and summer of 1980 with sledgehammers and blowtorches, but without hard hats, working twelve- to eighteen-hour days, seven days a week, often sleeping on Bonwit Teller's floors. They were paid less than $\$ 5$ an hour, sometimes in vodka. Many went unpaid and were threatened with deportation if they complained". In 1983, Harry Diduck filed a lawsuit against Donald Trump, arguing that workers were cheated in pension and welfare fund contributions not paid for the wages of the Polish workers (Justia 1991). There was a collective bargaining agreement between Kaszycki \& Sons and the House Wreckers Union Local 95. The case carried on until 1999 when a sealed settlement was reached (Robbins 1999).

This case indicates that illegal immigrants worked under horrible conditions at the Trump Tower's construction site. Trump's campaign made immigration a key issue and blamed immigrants for destroying American jobs and duping wages: "Donald J. Trump's Vision: - Prioritize the jobs, wages and security of the American people. Establish new immigration controls to boost wages and to ensure that open jobs are offered to American workers first. [...] Donald J. Trump's 10 Point Plan to Put America First: 1. Begin working on an impenetrable physical wall on the southern border, on 
day one. Mexico will pay for the wall"44. "“The first thing we need to do is secure our southern border - and we need to do it now. We have to stop that flood, and the best way to do that is to build a wall. [...] Nobody can build a wall like me. I will build a great wall on our southern border" (Trump 2015a, 23-24).

In a speech on immigration, Trump said:

When politicians talk about immigration reform, they usually mean the following: amnesty, open borders, and lower wages. [...] we have to listen to the concerns that working people have over the record pace of immigration and its impact on their jobs, wages, housing, schools, tax bills, and living conditions. These are valid concerns, expressed by decent and patriotic citizens from all backgrounds. [...] there is the case of 90 year-old Earl Olander, who was brutally beaten and left to bleed to death in his home. The perpetrators were illegal immigrants with criminal records who did not meet the Obama Administration's priorities for removal. [...] there is only one core issue in the immigration debate and it is this: the well-being of the American people. [...] there are at least 2 million criminal aliens now inside the country. We will begin moving them out day one, in joint operations with local, state and federal law enforcement. Beyond the 2 million, there are a vast number of additional criminal illegal immigrants who have fled or evaded justice. But their days on the run will soon be over. They go out, and they go out fast. [...] Let's secure our border. [...] Together, we can save American lives, American jobs, and American futures. Together, we can save America itself. Join me in this mission to Make America Great Again (Trump 2016a).

In this speech, Trump does not a single time mention and criticise how American capitalists exploit foreign workers, whom they pay extremely low wages in order to maximise profits. Instead he argues that illegal immigrants are criminal and have negative impacts on jobs, wages, housing, schools, etc. Observers of both illegal workers on Trump's construction site and his election campaign could argue that his position is hypocritical. Trump in his speech does not condemn companies' exploitation of illegal immigrants, a strategy they use for dumping wages in general, but rather blames immigrants themselves for social dumping, which detracts attention from social problem's real structural causes.

Trump announced in his election campaign the he wants to "begin working on an impenetrable physical wall on the southern border [between the USA and Mexico], on day one. Mexico will pay for the wall" ${ }^{\prime 5}$. Repeatedly he argued that such a wall is needed to stop crime: "Now, I want to build the wall. We need the wall. And the Border Patrol, ICE, they all want the wall. We stop the drugs. We shore up the border" (Clinton and Trump 2016c). "[W]e are letting people into this country that are going to cause problems and crime like you've never seen. We're also letting drugs pour through our southern border at a record clip. At a record clip. And it shouldn't be allowed to happen. [...] She wants amnesty for everybody. Come right in. Come right over. It's a horrible thing she's doing" (Clinton and Trump 2016b). "When Mexico sends its people, they are not sending their best. [...] They are bringing drugs, they are bringing crime, they are rapists. And some, I assume, are good people". "It's not only Mexico [...] They're coming from all over. [...] So we have this open border [...] And it's not just Mexicans. [...] And certainly we do have killers and plenty of other

\footnotetext{
${ }^{44}$ https://www.donaldjtrump.com/policies/immigration

${ }^{45}$ https://www.donaldjtrump.com/policies/immigration/
} 
problems coming over. We take them because other countries don't want them. We are like a dumping ground" 46 .

Such statements associate migration with crimes, drugs, rape, and killings. The point is that in such speeches and discussions there is hardly any mentioning of immigrants from Mexico and Latin America in general, who as everyday people live in the United States and work hard, pay taxes, and contribute to community life and civil society. By focusing on the exception from the rule, the impression is created that the exception is the norm. A study on immigrants and crime conducted by the American Immigration Council (2015) concluded:

According to an original analysis of data from the 2010 American Community Survey (ACS) conducted by the authors of this report, roughly 1.6 percent of immigrant males age 18-39 are incarcerated, compared to 3.3 percent of the native-born. This disparity in incarceration rates has existed for decades, as evidenced by data from the 1980, 1990, and 2000 decennial censuses. [...] The 2010 Census data reveals that incarceration rates among the young, lesseducated Mexican, Salvadoran, and Guatemalan men who make up the bulk of the unauthorized population are significantly lower than the incarceration rate among native-born young men without a high-school diploma. In 2010, lesseducated native-born men age 18-39 had an incarceration rate of 10.7 percent - more than triple the 2.8 percent rate among foreign-born Mexican men, and five times greater than the 1.7 percent rate among foreign-born Salvadoran and Guatemalan men" (American Immigration Council 2015, 1-2).

Generalising logic could also be found in a 2015 statement of the Trump campaign that said that "Donald J. Trump is calling for a total and complete shutdown of Muslims entering the United States until our country's representatives can figure out what is going on. According to Pew Research, among others, there is great hatred towards Americans by large segments of the Muslim population" (Trump 2015b)

Donald Trump has scapegoated immigrants for social problems, he has played with the fire of nationalism, has made ambivalent announcements about investigating Hillary Clinton, foreign workers were highly exploited in at least one of his construction projects, he resorted to personal abuse, and he seems to have no problem with Breitbart's intolerance, while condemning concerned citizens expressing fears about the increase of intolerance. Such circumstances indicate an authoritarian tendency. One has to wait and see if, and if so, how and to which extent this approach translates into authoritarian statism.

\subsection{International Relations under Trump}

International trade policies and foreign politics are two key aspects of international relations.

\subsubsection{International Relations 1: International Trade Policies}

The first dimension of international relations is that Trump promised in respect to trade policies to renegotiate or withdraw from free trade agreements such as the

\footnotetext{
${ }^{46}$ http://edition.cnn.com/videos/tv/2015/06/25/exp-presidential-candidate-donald-trumpimmigration-intv-erin.cnn
} 
North American Free Trade Agreement (NAFTA) and the Trans-Pacific Partnership (TPP).

Trump announced that "NAFTA will be renegotiated to get a better deal for American workers" 47 and that he will "[w]ithdraw from the Trans-Pacific Partnership, which has not yet been ratified"48. His election programme argued that Trump will "[t]ell NAFTA partners that we intend to immediately renegotiate the terms of that agreement to get a better deal for our workers. If they don't agree to a renegotiation, we will submit notice that the U.S. intends to withdraw from the deal. [We will] Eliminate Mexico's one-side backdoor tariff through the VAT and end sweatshops in Mexico that undercut U.S. workers" $" 49$.

Trump is sceptical of free trade agreements because he argues that they result in the undercutting of wages and the destruction of US manufacturing jobs: "America has lost nearly one-third of its manufacturing jobs since NAFTA and 50,000 factories since China joined the World Trade Organization" ${ }^{50}$. "So my plan - we're going to renegotiate trade deals. We're going to have a lot of free trade. We're going to have free trade, more free trade than we have right now. But we have horrible deals. Our jobs are being taken out by the deal that her husband signed, NAFTA, one of the worst deals ever. Our jobs are being sucked out of our economy. [...] Our jobs have fled to Mexico and other places" (Clinton and Trump 2016c). "Look, our country is stagnant. We've lost our jobs. We've lost our businesses. We're not making things anymore, relatively speaking. Our product is pouring in from China, pouring in from Vietnam, pouring in from all over the world. [...] I've visited so many communities" (Clinton and Trump 2016c). "The NAFTA agreement is defective. [...] And what you do is you say, fine, you want to go to Mexico or some other country, good luck. We wish you a lot of luck. But if you think you're going to make your air conditioners or your cars or your cookies or whatever you make and bring them into our country without a tax, you're wrong. And once you say you're going to have to tax them coming in, and our politicians never do this, because they have special interests and the special interests want those companies to leave, because in many cases, they own the companies" (Clinton and Trump 2016a).

So taken together, Trump makes two arguments in respect to free trade agreements:

1) As a result of free trade agreements, cheap commodities are flooding the US market.

2) As a result of free trade agreements, US manufacturing jobs are leaving the USA and are being conducted for lower wages in other countries. The solution would be tariffs and the re-negotiation of trade agreements that does not eliminate free trade, but transforms it.

Trump (2016d) sees NAFTA as a "one-way street", which creates the impression that other countries and people living there have only benefited and the USA has only had disadvantages from NAFTA. NAFTA came into effect on January 1, 1994, and subsequently eliminated constraints on cross-border capital investments in and trade between Canada, Mexico, and the United States. On January 2, 1994, the Zapatista uprising started in Chiapas, Mexico's poorest region. It was explicitly directed against NAFTA. In 1991, Mexico's President Salinas abolished the system of land tenure to

\footnotetext{
${ }^{47}$ https://www.donaldjtrump.com/press-releases/fact-sheet-donald-j.-trumps-pro-growtheconomic-policy-will-create-25-milli

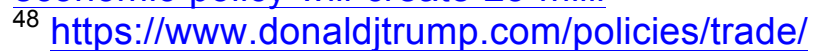

49 https://www.donaldjtrump.com/policies/trade/

50 https://www.donaldjtrump.com/policies/trade/
} 
qualify for NAFTA participation. In 1992, "he removed existing restrictions on the size of the large estates and abolished the Ejido Law in order to clear the way for privatization of the land and thus allow national and foreign agribusiness to grow cash crops for export, violating the inalienability of ejido lands in Article 27 of the Mexican Constitution of 1917" (Marcos 2002, 429). The Zapatista rebels assessed "that NAFTA will not bring them benefits, but 'a death sentence'" (Marcos 2002, xxv).

Mexico's socio-economic situation has not really improved through NAFTA: In the period from 1994-2013, Mexico's GDP increased on average by only 0.9 percent per year (Weisbrot, Lefebvre and Sammut 2014). Mexico's poverty rate was in 2012 $52.3 \%$ and in $199452.4 \%$, so the country stayed extremely poor during NAFTA's first twenty years (ibid.). Real wages stagnated (ibid.). "NAFTA removed tariffs (but not subsidies) on agricultural goods, with a transition period in which there was a steadily increasing import quota for certain commodities. The transition period was longest for corn, the most important crop for Mexican producers, only ending in 2008 . Not surprisingly, U.S. production, which is not only subsidized but had higher average productivity levels than that of Mexico, displaced millions of Mexican farmers" (Weisbrot, Lefebvre and Sammut 2014, 13). In the years 1991-2007, Mexico lost more than 2 million jobs in agriculture and forestry, which is a level of $19 \%$ (ibid., 13).

The number of Mexican Maquiladora factories has especially been expanding since NAFTA came into effect. Maquiladoras exist as part of Special Economic Zones, especially in Northern Mexican border cities such as Ciudad Juárez, Heroica Nogales, Matamoros, Mexicali, and Tijuana. They make use of NAFTA for importing materials tariff- and duty-free, are known for low wages and harsh working conditions, and export the end products back to the countries of the resources' origin. Important industries involved in maquiladoras are those that produce machinery, chemicals, automotive parts, furniture, electronics, textiles, packaging, plastics, metal, medical devices, and call centre services (Dorocki and Brzegowy 2014, figure 3 \& 4). "The mission of the maquiladoras" is "lowering labor costs by importing and processing raw materials to be exported as finished products back to the country of origin - normally to the United States" (Dorocki and Brzegowy 2014, 94). In the period from 1994 until 2006, US companies accounted for $88.4 \%$ of all capital investments in Mexican maquiladoras (Dorocki and Brzegowy 2014, table 1). In 2012, there were more than 5,000 maquiladoras with a total of more than 2 million employees (Dorocki and Brzegowy 2014, table 2). Piece wages are common in maquiladoras. Maquiladora workers tend to be paid at a fraction of their US equivalents, tend to work long hours and to face difficult working conditions.

The 2017 Californian minimum wage is US\$10.5 per hour for companies that employ more than 25 employees and US\$ 10.0 for smaller companies ${ }^{51}$. The 2017 Mexican daily minimum wage is 80.04 pesos $^{52}$ (approximately US\$ 3.9). In September

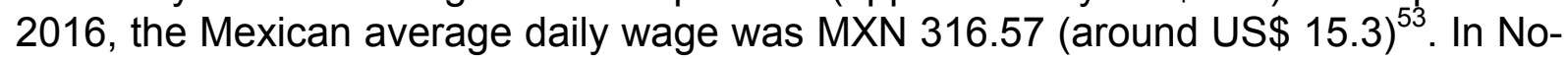
vember 2016, the average daily earnings of employees in the USA were around US\$ $178^{54}$. This means that the average wage is twelve times higher in the USA than in Mexico. Tijuana is a town located in the Mexican state Baja California. It is based right on the border to California. In Tijuana, one of the maquiladora industry's centres, manufacturing workers' average monthly salary was in the year 2016 US $\$ 304$

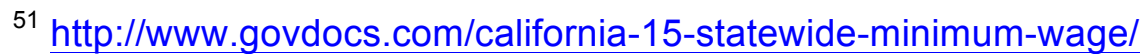

52 http://zetatijuana.com/2016/12/01/la-consami-sube-7-36-pesos-al-salario-minimo-a-partirdel-2017/

${ }^{53} \mathrm{http}: / / \mathrm{w} w \mathrm{w}$.tradingeconomics.com/mexico/wages

${ }^{54}$ Calculation based on: http://www.bls.gov/news.release/empsit.t19.htm
} 
for unskilled workers and US\$368 for highly skilled workers ${ }^{55}$. In California, production workers' average monthly salary was US $\$ 2980^{56}$. So the average manufacturing wage was 10 times lower in Tijuana than in California. The implication is that US companies can use NAFTA for reducing labour costs by a factor of around 10 in order to maximise their profits.

The point is that NAFTA helps both US corporations as well as Mexican suppliers to increase their profits, whereas Mexican workers are paid at relatively low levels and US manufacturing workers lose their jobs. The international working class is the overall loser. The problem of Trump's analysis is that he presents NAFTA in a onesided and nationalist manner as an issue of nations, whereas it is in reality an issue of class. Trump seems only to care about US corporations' profits, whereas the reality is that through NAFTA international capital takes advantage of the working class in Mexico, the USA and Canada.

Robert Scott (2011) argues in an analysis published by the Economic Policy Institute that NAFTA has been the context for the circumstance that "U.S. trade deficits with Mexico as of 2010 displaced production that could have supported 682,900 U.S. jobs " (2). The basic reason would have been foreign direct investments of US capital in Mexico. $22 \%$ of these jobs would have been in the manufacturing of computer and electronic parts, $15.8 \%$ in the manufacturing of cars and the production of automotive parts.

When Trump argues that NAFTA destroys US jobs and therefore should be renegotiated or abolished, he in a nationalist manner only sees the US side of the coin, but disregards that NAFTA seems to also have destroyed over two million agricultural jobs in Mexico because of the USA's export of subsidised corn and cheap grain.

The same issue arises in respect to China. Trump argues: "And Apple, and our other major companies, will start making their iPhones, computers and other products inside of the United States - not in China, and all over the world" (Trump 2016d). "There are people who wish I wouldn't refer to China as our enemy. But that's exactly what they are. They have destroyed entire industries by utilizing low-wage workers, cost us tens of thousands of jobs, spied on our businesses, stolen our technology, and have manipulated and devalued their currency, which makes importing our goods more expensive - and sometimes, impossible" (Trump 2015a, 43). The basic problem is that the international division of labour does not benefit Chinese and American workers, but both Apple that exports labour and capital and Foxconn, in whose Chinese factories Apple tools are assembled under precarious conditions (Fuchs 2017b, Qu 2016). For Trump the issue is one of nation and nationalism, not one of capitalism's structural contradictions. He uses the friend/enemy scheme when opposing the Chinese nation to the American nation.

Donald Trump criticises China's export of substituted steel at cheap prices: "You take a look at what's happening to steel and the cost of steel and China dumping vast amounts of steel all over the United States, which essentially is killing our steelworkers and our steel companies" (Clinton and Trump 2016b). Newsweek reports that an investigation it conducted "has found that in at least two of Trump's last three construction projects, Trump opted to purchase his steel and aluminium from Chinese manufacturers rather than United States corporations based in states like Pennsylvania, Ohio, Michigan and Wisconsin. [...] Of Trump's last three construction projects,

\footnotetext{
${ }^{55} \mathrm{http}: / /$ www.estradayasociados.com.mx/area-information/baja-california/labor-wages

${ }^{56}$ Data source: Bureau of Labour Statistics, http://www.bls.gov/oes/current/oes_ca.htm\#51-

0000, accessed on December 4, 2016.
} 
the first to use Chinese steel was Trump International Hotel Las Vegas, which opened in 2008. [...] According to government documents, the Chinese entity chosen by Trump to provide steel for the Las Vegas property is a holding company called Ossen Innovation Co. Ltd.-formerly known as Ultra Glory International Ltd. [...] Another recent Trump building that has used metal from China is Trump International Hotel and Tower in Chicago, which opened in 2009. [...] Because American businesses have been turning to cheaper aluminium from overseas, the industry is collapsing. For example, in just the last two years, more than half of the country's aluminium smelters in states like Ohio, West Virginia and Texas have closed as a result of being undercut on price by competition from overseas" (Eichenwald 2016).

So it looks like although Trump criticises capitalists making use of structural advantages for increasing their profits at the expense of US workers, according to these reports his own company made use of such mechanisms, which questions how credible and authentic his political commitments are.

How does Trump respond to this type of criticism? "The same thing is true with having my products made in China or Mexico or other countries. Some have attacked me for urging that we complain about these countries at the same time I'm having goods manufactured there. My response: I'm a realist. I'm a competitor. When I am working on a business deal, I make the best deal. But we should be changing the business climate so that manufacturers can get the best deal right here in the US. Right now it doesn't work that way. We need legislation that gives American companies the tax priorities and financial support to create more of their technology and to redirect more of their manufacturing here at home" (Trump 2015a, 86).

Trump's answer is to create investment conditions for capital in the USA that keep capital there and attract new capital. Given the contradictory nature of capitalism, good business climate also tends to mean, as the example of China shows, low wages in order to increase profits. When Trump talks about his vision of making the American economy great again, then increasing minimum wages, guaranteeing everyone earns a living wage, and the importance of trade unions are missing (see Trump 2015a).

\subsubsection{International Relations 2: Foreign Politics}

Foreign politics constitutes the second element of international relations. Donald Trump has announced that other NATO members will have to contribute more to the alliance's budget if they want to count on the USA's support. He plans a trade war with China, co-operation with Russia and Syria, a military offensive against ISIS, and a tough stance on the Iran nuclear deal. His plans include to:

- "- End the current strategy of nation-building and regime change. [...] - Pursue aggressive joint and coalition military operations to crush and destroy ISIS, international cooperation to cutoff their funding, expand intelligence sharing, and cyberwarfare to disrupt and disable their propaganda and recruiting. [...] - Suspend, on a temporary basis, immigration from some of the most dangerous and volatile regions of the world that have a history of exporting terrorism" 57 .

- In respect to NATO, Trump said: "Number one, the 28 countries of NATO, many of them aren't paying their fair share. Number two - and that bothers me, because we should be asking - we're defending them, and they should at least be paying us what they're supposed to be paying by treaty and contract. And, number two, I

\footnotetext{
${ }^{57}$ https://www.donaldjtrump.com/policies/foreign-policy-and-defeating-isis/
} 
said, and very strongly, NATO could be obsolete, because [...] they do not focus on terror. [...] we pay approximately 73 percent of the cost of NATO. It's a lot of money to protect other people. But I'm all for NATO. But I said they have to focus on terror, also." (Clinton and Trump 2016a). "We defend Germany. We defend Japan. We defend South Korea. These are powerful and wealthy countries. We get nothing from them" (Trump 2015a, 34).

- On ISIS: "I think we have to get NATO to go into the Middle East with us, in addition to surrounding nations, and we have to knock the hell out of ISIS, and we have to do it fast, when ISIS formed in this vacuum created by Barack Obama and Secretary Clinton" (Clinton and Trump 2016a)

- On Putin and Russia: "Now we can talk about Putin. I don't know Putin. He said nice things about me. If we got along well, that would be good. If Russia and the United States got along well and went after ISIS, that would be good. He has no respect for her [Hillary Clinton]. He has no respect for our president. And I'll tell you what: We're in very serious trouble, because we have a country with tremendous numbers of nuclear warheads $-1,800$, by the way - where they expanded and we didn't, 1,800 nuclear warheads. And she's playing chicken" (Clinton and Trump 2016c).

- On Cuba: "Today, the world marks the passing of a brutal dictator who oppressed his own people for nearly six decades. [...] Fidel Castro's legacy is one of firing squads, theft, unimaginable suffering, poverty and the denial of fundamental human rights. While Cuba remains a totalitarian island, it is my hope that today marks a move away from the horrors endured for too long, and toward a future in which the wonderful Cuban people finally live in the freedom they so richly deserve. [...] Though the tragedies, deaths and pain caused by Fidel Castro cannot be erased, our administration will do all it can to ensure the Cuban people can finally begin their journey toward prosperity and liberty. I join the many CubanAmericans who supported me so greatly in the presidential campaign, including the Brigade 2506 Veterans Association that endorsed me, with the hope of one day soon seeing a free Cuba." (Scott 2016). "If Cuba is unwilling to make a better deal for the Cuban people, the Cuban/American people and the U.S. as a whole, I will terminate deal" ${ }^{\prime 58}$.

Trump seems to operate with a clear friend/enemy-scheme, in which the enemies must be crushed and one keeps out of alliances that do not tackle these enemies. It might very well be that Trump's foreign politics will not be isolationist, but unilateralist and highly unpredictable so that the future of the world may be at risk. In any case, he argues for massive armament: "'Iron Mike' Tyson, the famous fighter, once explained his philosophy, saying, 'Everybody has a plan until they get punched in the mouth.' The first thing we need to do is build up our ability to throw that punch. We need to spend whatever it takes to completely fund our military properly. [...] Everything begins with a strong military. Everything. We will have the strongest military in our history, and our people will be equipped with the best weaponry and protection available. Period. That means the best missile systems, the best cyber-warfare training and equipment, and the best-trained soldiers" (Trump 2015a, 32-33, 47).

Trump describes himself as "aggressive in military and foreign policy" (Trump 2015a, 98). "No enemy, and no enemy, leader should misinterpret our resolve to fight to the death - their death" (Trump 2015a, 138). The problem of the complexity of in-

\footnotetext{
${ }^{58}$ https://twitter.com/realDonaldTrump/status/803237535178772481
} 
ternational political relations involves the possibility of nuclear warfare. So fighting a nation to its death may at the same time mean the end of life on Earth.

Trump appointed US Marine General James Mattis as defence secretary. According to news reports, Mattis for example said: "Actually, it's a lot of fun to fight. You know, it's a hell of a hoot. [...] It's fun to shoot some people. I'll be right up front with you, I like brawling"; "You go into Afghanistan, you got guys who slap women around for five years because they didn't wear a veil. [...] You know, guys like that ain't got no manhood left anyway. So it's a hell of a lot of fun to shoot them" (Associated Press 2016).

Trump argues: "When somebody screws you, screw them back in spades. [...] When someone attacks you publicly, always strike back. [...] Go for the jugular so that people watching will not want to mess with you" (Trump and Zanker 2008, 199). Given that Trump believes in a world that is full of enemies, it may be quite unpredictable what he does in a situation of a highly polarised political conflict. In international politics, it is not always clear what the frontlines are and who the political aggressor is. The Soviet Union felt threatened by the deployment of US nuclear weapons in Italy and Turkey. The USA felt threatened by the deployment of Soviet nuclear weapons in Cuba. Each blamed the other. The problem is that warfare, competition and conflict often result in vicious cycles of aggression, violence, and armament. It is in such situations difficult to make out who started the conflict and each side blames the other for it. If a highly polarised international political situation occurred under Donald Trump's presidency and he applied the logic "When somebody screws you, screw them back in spades. When someone attacks you publicly, always strike back. Go for the jugular so that people watching will not want to mess with you", then a nuclear war might be the result.

On December 22, Trump tweeted about expanding the USA's nuclear armament (see figure 6). On the same day, Vladimir Putin said Russia needs "to strengthen the military potential of strategic nuclear forces" ${ }^{\text {. }}$. Given Putin and Trump's announcements, a new nuclear arms race seems to be in the making that certainly increases the chances of a nuclear war and planetary destruction. Trump commented: "Let it be an arms race. We will outmatch them at every pass and outlast them all"60. The point is that not armament, but only disarmament will end the threat of such a catastrophe that could easily wipe out humankind.

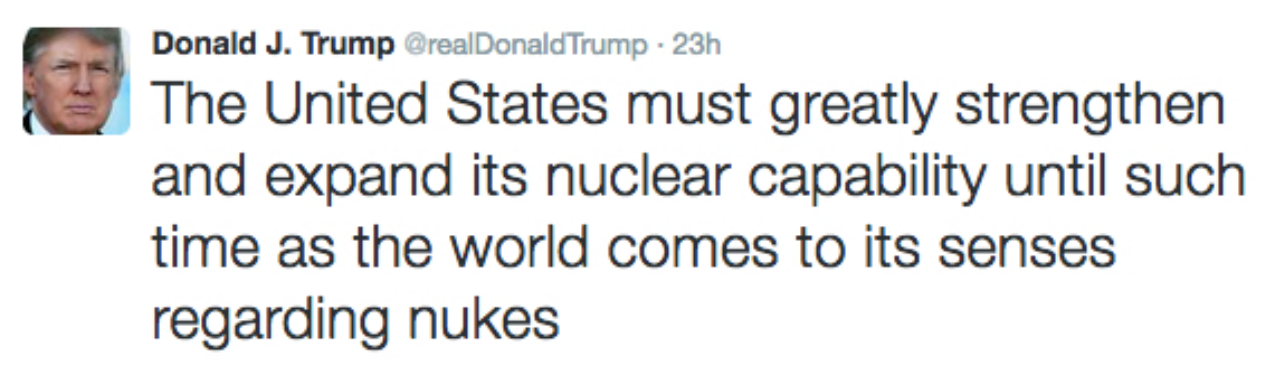

Figure 6: Donald Trump tweets about nuclear armament

\footnotetext{
${ }^{59}$ http://www.itv.com/news/2016-12-22/donald-trump-vladimir-putin-us-russia-nuclearweapons/

${ }^{60}$ http://www.cnbc.com/2016/12/23/trump-to-putin-lets-have-a-nuclear-arms-race.html
} 
So what lots of people fear is that Trump's personality is too uncontrolled and too revengeful, which could be dangerous in a ticklish political situation. The fear is that he may press the nuclear button. Whereas toughness, retaliation and brutality are the very features of capitalism, witch which capitalist corporations are confronted day by day in competition in order to survive, the rest of society does not automatically follow the same logic. Although the logic of the survival of the fittest also tends to be imitated in politics, there are boundaries of this logic that when crossed result in situations of no return, in which political violence escalates. The logic of Social Darwinism can in politics easily lead to the extinction of mankind.

The point is that such dangerous situations can only be overcome if both sides talk to each other, overcome their individual standpoints, and make compromises. So for example the Cuban missile crisis could only be overcome because John F. Kennedy and Nikita Khrushchev communicated with each other and Robert Kennedy and the Soviet Ambassador Anatoly Dobrynin met secretly and agreed that the USA would remove its missiles from Turkey and Italy and the Soviet Union its missiles from Cuba. Diplomacy and communication seem to be the important features of mastering such dangerous situations in international politics. So the question is whether Donald Trump has what it takes for international diplomacy. If it turns out that the answer is "No", the world may come to an end. Only history will tell.

In 2016, ExxonMobil was the world's $9^{\text {th }}$ largest transnational company and the largest oil and gas corporation ${ }^{61}$. In 2015 , it made profits of US\$16.2 billion. Donald Trump appointed ExxonMobil's CEO Rex Tillerson as US secretary of state. As secretary of state, Tillerson does of course not keep up his role as CEO. But having spent more than forty years working for ExxonMobil, it is unlikely he can easily leave behind his past and the interests of the industry that he represented for decades.

The US secretary of state is in charge of foreign policy and diplomacy and is one of the US cabinet's most influential politicians. Wars have been fought over oil because oil is such a crucial resource for keeping fossil capitalism going, wars have been fought over it. If the oil and gas industry's interests determine foreign policy, then there is a danger that not prospects for democracy and human rights, but business interests determine international relations. Eric Ferrero, director of communications for Amnesty International USA, asked: "We know that Tillerson has been successful in safeguarding the interests of a massive oil company - will he be as invested in safeguarding human rights abroad?"62 John Sauven, who is Greenpeace UK's executive director, commented: "So a real-life JR Ewing becomes America's chief diplomat as Donald Trump does away with the usual intermediaries and directly outsources foreign policy to the fossil fuel industry. We spent years warning that Exxon was too close to the US government. Now they are the government" (Gambino and Yuhas 2016).

Exxon Mobil has been subject to a lawsuit concerning allegations of human rights violations:

In 2001, eleven Indonesian villagers filed suit against ExxonMobil in US federal court alleging that the company was complicit in human rights abuses committed by Indonesian security forces in the province of Aceh. The plaintiffs maintain that ExxonMobil hired the security forces, who were members of the Indo-

${ }^{61}$ Data source: Forbes 2000, 2016 list

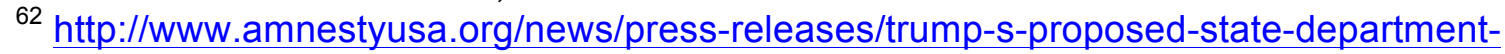
leadership-deeply-concerning 
nesian military, to protect the natural gas extraction facility and pipeline which ExxonMobil was operating. The plaintiffs further claim that ExxonMobil knew or should have known about the Indonesian military's human rights violations against the people of Aceh. The plaintiffs allege that they suffered human rights violations, such as murder, torture and rape, at the hands of these security forces. [...] In a decision issued in July 2015 , a US federal court ruled that the plaintiffs' claims sufficiently "touch and concern" the United States and may proceed in US court ${ }^{63}$.

\section{Trumpology: Ideology and the State under Trump}

There is a complex relationship between politics and culture in general and the state and ideology in capitalist society. The state's collective and individual actors produce meanings about society, and individuals and groups in society make meaning of the state. We can therefore distinguish between discourses by the state and discourses on the state.

In discourses by the state, politicians, parties, governments, political institutions or communication workers employed by such state institutions produce and communicate specific interpretations of society to the public. A government or party programme is an example. In discourses on the state, individuals and groups in society interpret what state actors and institutions are doing and express and communicate these interpretations in semiotic forms. Examples are a conversation about the government between friends, media reports about a political event, or a consultancy agency's development of a communication strategy for a political party. Discourses are semiotic representations of reality through which humans communicate and make meanings of certain aspects of the world. Discourses by the state can therefore also be called semiotic representations by the state. Discourses on the state can also be termed semiotic representations of the state.

Discourses by and on the state are to specific degrees ideological in character, i.e. ideologies by the state and ideologies on the state. In ideologies by the state, state actors justify domination and/or exploitation. In ideologies on the state, individuals or groups justify state actions that enact, practice or justify domination and/or exploitation. The distinction between discourses and ideologies points towards the potentially contradictory character of discourses by the state and discourses on the state so that they may have a contested character.

Given that Trump is the US president, his general view of the world is relevant for understanding the state's ideology (ideology by the state) during his rule. Having a look at his ideological views may also reveal what role he assigns to the state in society (ideology on the state). Trumpology is Trump-style ideology. It is not the ideology of a single person, but rather a whole way of thought and life that consists of elements such as hyper-individualism, hard labour, leadership, the friend/enemyscheme, and Social Darwinism.

\subsection{Possessive Hyper-Individualism}

Hyper-individualism is Trumpology's first element. Trump is a brand. Trump is a strategy. Trump is entertainment. Trump is a spectacle. Trump is politics. Trump is the instrumentalisation of everything surrounding him. Trump is the absolute com-

\footnotetext{
${ }^{63}$ https://business-humanrights.org/en/exxonmobil-lawsuit-re-aceh
} 
modification of the self. Donald Trump made a career by branding and selling himself. His presidential campaign was also focused on Trump as brand, celebrity, billionaire and political leader. As a consequence, Trump likes talking in the first person singular. "I", "me", "my" and "mine" are among his most frequently used words. Trumpology is about possessive individualism, the individual as owner.

Consider the following example:

Whenever I start something new, I know I have tons to learn. I see each new project as a blank page that I can't wait to fill. I get excited because I love to investigate, dig in new areas, acquire information, put it together, and gain an indepth understanding of something completely new. I've had this feeling at every stage of my career; it's how I begin every successful project. I consider it a sign; if I don't feel excited, I usually pass on the opportunity, even if it could produce huge profits. My enthusiasm drives me to learn, and what I learn gives me more control. My knowledge also helps me avoid mistakes and eliminate problems that could arise. I studied up on travel before starting GoTrump.com, my travel agency. I studied the men's fashion industry for my Donald J. Trump Signature Collection of menswear. I researched and read carefully before starting Trump University; and that's just to name a few examples (Trump 2007, 94-95).

This short passage from Trump's book Trump 101: The Way to Success consists of nine sentences, in which the term "I" occurs sixteen times, "my" five times, and "me" three times. This means that in this passage, Trump on average uses the first person singular 2.3 times per sentence.

The philosopher Erich Fromm (1997, 91-92) characterises possessive individualism as a having-centred ideology of accumulation:

Speaking more generally, the fundamental elements in the relation between individuals in the having mode of existence are competition, antagonism, and fear. The antagonistic element in the having relationship stems from its nature. If having is the basis of my sense of identity because "I am what I have," the wish to have must lead to the desire to have much, to have more, to have most. In other words, greed is the natural outcome of the having orientation. It can be the greed of the miser or the greed of the profit hunter or the greed of the womanizer or the man chaser. Whatever constitutes their greed, the greedy can never have enough, can never be "satisfied." In contrast to physiological needs, such as hunger, that have definite satiation points due to the physiology of the body, mental greed - and all greed is mental, even if it is satisfied via the body - has no satiation point, since its consummation does not fill the inner emptiness, boredom, loneliness and depression it is meant to overcome. In addition, since what one has can be taken away in one form or another, one must have more, in order to fortify one's existence against such danger. If everyone wants to have more, everyone must fear one's neighbor's aggressive intention to take away what one has. To prevent such attack one must become more powerful and preventively aggressive oneself.

Trump summarises his philosophy: "A big ego is a positive thing" (Trump and Zanker 2008, 280). His individualism is his capital accumulation strategy. His self is the commodity he sells. 


\subsection{Performance and the Ideology of Hard Labour}

Trumpology's second element is the ideology of hard labour. "My father didn't give me much money, but what he did give me was a good education and the simple formula for getting wealthy: work hard doing what you love" (Trump and Zanker 2008, 44). "Hard work is my personal method for financial success" (32) "You can help create your own luck, you can make things happen through hard work and intelligence. You can become luckier" (114). "The harder you work, the luckier you get" (135). Celebrities, billionaires, successful businesspeople and superstars' "attitudes, actions, persistence, and passion [...] separate the winners from the losers" (1).

The implication is that the working poor do not work or do not work hard enough. News sources say that Trump's father Fred, a rich real estate developer, supported his son financially in a significant manner at the start of his career, on other occasions and when Donald faced financial problems (Kranish and Fisher 2016, 75, 95, 124-125, 201, 294). Of course good parents want to see their children thrive and be happy and therefore try to support them. But some can do so more than others. And rich parents can do so in a very powerful way. As a result, in capitalism some tend to be luckier than others because they had the luck to be born into wealthy families.

\subsection{The Leadership Ideology}

Leadership thinking is Trumpology's third element. "I'm not bragging when I say that I'm a winner. I have experience in winning. That's what we call leadership. That means that people will follow me and be inspired by what I do. How do I know? l've been a leader my whole life" (Trump 2015a, 9). "Leadership is not a group effort. If you're in charge, then be in charge. [...] l'm the conductor who leads the Trump Organization; I set the tempo. In my organization, I set a rapid pace, which is called allegro in symphonic circles. I pay close attention to tempo because I know that it's vital to keep the momentum going at all times. I provide strong leadership, and, at times, this can be hard and not what I want to do" (Trump 2007, 101, 125-126).

Trump also thinks of politics in terms of leadership. The very ideology of making America great again is based on the assumption that the USA needs to be the leader of the world in every respect: "The idea of American Greatness, of our country as the leader of the free and unfree world, has vanished" (Trump 2015a, xi). And Trump argues that making the USA lead the world needs a strong leader who manages the country and the world like a company:

Despite all of these challenges - and actually because of the challenges - I decided to do something about it. I couldn't stand to see what was happening to our great country. This mess calls for leadership in the worst way. It needs someone with common sense and business acumen, someone who can truly lead America back to what has made us great in the past. We need someone with a proven track record in business who understands greatness, someone who can rally us to the standard of excellence we once epitomized and explain what needs to be done (Trump 2015a, xi).

Another associated argument that Trump frequently employs is that career politicians are weak leaders: "In politics, once someone gets elected, it's tough to get them out. There's no motivation to try to get anything done. [...] Career politicians like it this 
way; being a politician is their career. I know many of them; believe me, they couldn't get a job in private industry. They don't want anyone taking away their great pension plan and health benefits - that you are paying for" (Trump 2015a, 94).

\subsection{Social Darwinism \& the Friend/Enemy-Scheme}

Social Darwinism and the friend/enemy scheme form Trumpology's fourth dimension. Social Darwinism is a highly competitive and militaristic view of society, in which there is constant egoism, battle, conflict, and war. It is based on the assumption that only the strong can and should survive and that survival requires crushing enemies.

"The world is a vicious and brutal place. We think we're civilized. In truth, it's a cruel world and people are ruthless. [...] People will be mean and nasty and try to hurt you just for sport. Lions in the jungle only kill for food, but humans kill for fun" (Trump and Zunker 2008, 29).

"Everyone wants to kill the fastest gun" (176).

"The same burning greed that makes people loot, kill, and steal in emergencies like fires and floods, operates daily in normal everyday people. It lurks right behind the surface, and when you least expect it, it rears its nasty head and bites you. Accept it. The world is a brutal place. "I love to crush the other side and take the benefits. Why? Because there is nothing greater. For me it is even better than sex, and I love sex" (48).

When somebody screws you, screw them back in spades. [...] Go for the jugular so that people watching will not want to mess with you (199).

Using such descriptions, Trump certainly gives a realist picture of capitalism. Capitalism is per definition a machine of capital accumulation that operates with economic life and death as its inputs and outputs. But if all aspects of society were driven by war-like competition, then society could not exist. And expanding and intensifying this logic brings about existential threats for society. Basing politics on the logic of the "survival of the fittest" poses the danger of heavy military instead of diplomatic responses to political disagreements. If such situations where the logic of the survival of the fittest prevails between powerful nations (such as the USA on the one side and China, Russia or Iran on the other side), then spirals of violence can occur that escalate. Thinking this logic to the end means that Social Darwinism in society not just poses the threat of a World War, but of nuclear destruction.

\subsection{Trump and the Media}

Trumpology does not simply exist because of a single individual. Like any ideology, it requires hegemony. It requires those who admire Trump as brand and leader. And it also requires public visibility. Trumpology needs Trump as media spectacle. The Trump spectacle has two dimensions. On the one side Trump understands well how to stage himself as scandalous spectacle in order to attract media attention. On the other side the media also need someone like Trump for staging spectacles that attract a large audience. There is a profit motive on both sides of mediated Trumpology spectacles: The one side is looking for advertising, marketing and public relations 
opportunities in order to be able to better sell a range of branded commodities. The other side is looking for content that attracts a large audience and thereby allows selling advertising space expensively.

The reporting and content can be quite contentious, with reporters trying to unveil ever more scandals and nastiness. The response is criticisms of the media and the claim of unfair treatment in the media. It is this contentiousness that keeps the spectacle machinery going, creates the need for more scandals, more controversy, more spectacles, and possibly more audience attention and thereby more profits and attention for both the mainstream media and their subject of coverage. Contention and symbiosis are two poles of the Trump spectacle's dialectic that drives profitability. By Trump making news in the media, the media make Trump.

Bernie Sanders $(2016 \mathrm{~b}, 421)$ argues that he learned from having media exposure during the Democratic Party's primaries that "the more important the issue is to large numbers of working people, the less interesting it is to corporate media" .

[T] he nature of media coverage today, especially on television, mostly calls for short sound bites on what the media establishment determines is the "issue of the day. [..] For the corporate media, the real issues facing the American people - poverty, the decline of the middle class, income and wealth inequality, trade, health care, climate change, etc. - are fairly irrelevant. For them, politics is largely presented as entertainment. [...] Turn on CNN or other networks covering politics and what you will find is that the overwhelming amount of coverage is dedicated to personality, gossip, campaign strategy, scandals, conflicts, polls and who appears to be winning or losing, fund-raising, the ups and downs of the campaign trail, and the dumb things a candidate may say or do. Political coverage is the drama of what happens on the campaign trail. It has very little to do with the needs of the American people and the ideas or programs a candidate offers to address the problems facing the country. [...] The "politics as entertainment" approach works very well for someone like Donald Trump, an experienced entertainer. [...] For the corporate media, name-calling and personal attacks are easy to cover, and what it prefers to cover (Sanders 2016b, 424-425).

Trump is quite aware of this peculiar relationship between him and the mainstream media:

The personal exchanges between me and others become the big story of the debate and the focus of news coverage for weeks. [...] I use the media the way the media uses me - to attract attention. [...] So sometimes I make outrageous comments and give them what they want - viewers and readers - in order to make a point. I'm a businessman with a brand to sell. [...] The cost of a fullpage ad in the New York Times can be more than $\$ 100,000$. But when they write a story about one of my deals, it doesn't cost me a cent, and I get more important publicity. I have a mutually profitable two-way relationship with the media - we give each other what we need. And now I am using that relationship to talk about the future of America. [...] These media types sell more magazines when my face is on the cover, or when I bring a bigger audience to their television show than they normally attract, and by far. And what's funny is that it turns out the best way for them to get that attention is to criticize me" (Trump 2015a, $10,11,14)$. 
In the 2016 US presidential, the tech pundits pronounced that big data was the factor determining election results. So for example Wired Magazine wrote that the "marriage of big data, social data will determine the next President" and summarised this claim in a simple formula: "Big Data + Social Data = Your Next President" ${ }^{\text {" }}$. There are indications that the Clinton campaign's data spending was much higher. Data show that in October 2016, the Clinton campaign had raised US\$1.3 billion, the Trump campaign just US\$795 million ${ }^{65}$. The table below shows for both campaigns' spending on tech and data in June 2016. According to this source, the Clinton campaign not just invested a higher share of its budget on data and tech than the Trump campaign, but it spent 3.7 times what the Trump campaign invested.

\begin{tabular}{|l|l|l|l|l|}
\hline & $\begin{array}{l}\text { Trump, total spend- } \\
\text { ing }\end{array}$ & $\begin{array}{l}\text { Trump, \% } \\
\text { of spending }\end{array}$ & $\begin{array}{l}\text { Clinton, total } \\
\text { spending }\end{array}$ & $\begin{array}{l}\text { Clinton, \% of } \\
\text { spending }\end{array}$ \\
\hline $\begin{array}{l}\text { Web development } \\
\text { and digital consulting }\end{array}$ & $\$ 2.5 \mathrm{~m}$ & $3.3 \%$ & & \\
\hline $\begin{array}{l}\text { Telemarketing and } \\
\text { data }\end{array}$ & $\$ 1.5 \mathrm{~m}$ & $1.9 \%$ & $\$ 0.2 \mathrm{~m}$ & $0.1 \%$ \\
\hline Software & $\$ 0.3 \mathrm{~m}$ & $0.3 \%$ & & \\
\hline Data management & $\$ 0.2 \mathrm{~m}$ & $0.2 \%$ & & \\
\hline Online advertising & $\$ 0.1 \mathrm{~m}$ & $0.2 \%$ & $\$ 11.6 \mathrm{~m}$ & $5.1 \%$ \\
\hline Digital consulting & $\$ 0.1 \mathrm{~m}$ & $0.1 \%$ & $\$ 0.7 \mathrm{~m}$ & $0.3 \%$ \\
\hline Technology services & & & $\$ 1.6 \mathrm{~m}$ & $0.7 \%$ \\
\hline Computers & & & $\$ 1.5 \mathrm{~m}$ & $0.7 \%$ \\
\hline Database services & & & $\$ 0.5 \mathrm{~m}$ & $0.2 \%$ \\
\hline $\begin{array}{l}\text { Technology consult- } \\
\text { ing }\end{array}$ & & & $\$ 0.4 \mathrm{~m}$ & $0.2 \%$ \\
\hline $\begin{array}{l}\text { Design and web } \\
\text { development }\end{array}$ & & & $\$ 0.3$ & $0.1 \%$ \\
\hline Voter file & & & $\$ 0.4 \mathrm{~m}$ & $0.2 \%$ \\
\hline E-mail services & & & $\$ 0.2 \mathrm{~m}$ & $0.1 \%$ \\
\hline List rental & & $6.0 \%$ & $\$ 1 \% .2 \mathrm{~m}$ & $0.3 \%$ \\
\hline Total & $\$ 4.7 \mathrm{~m}$ & & $8.00 \%$ \\
\hline
\end{tabular}

Table 7: Campaign spending on tech and data in June 2016 (data source: Bloomberg Politics, https://www.bloomberg.com/politics/graphics/2016-presidential-campaignfundraising/july/public/index.html)

Big data does not win and cannot predict elections. It is a techno-fetishistic myth to believe that the more money a campaign invests into data analytics, the larger the likelihood of electoral success. It is the complex combination of structural conditions, economic and political contradictions, crises, political subjectivities, political structures of feeling, ideological factors, organising, campaigning and communication that determines election results. Data, algorithms and tech form just one of many relevant factors. In the 2016 US presidential election, right-wing ideology trumped over big data politics.

But Trump is after Narendra Modi the world's second populist Twitter president. Trump uses Twitter as political spectacle. A study estimates that in the third US presidential election debate, political bots posted $36.1 \%$ of the pro-Trump tweets and $23.5 \%$ of the pro-Clinton tweets (Kollanyi, Howard and Woolley 2016). So automated

\footnotetext{
${ }^{64}$ https://www.wired.com/insights/2013/05/election-2016-marriage-of-big-data-social-datawill-determine-the-next-president ${ }^{65}$ https://www.washingtonpost.com/graphics/politics/2016-election/campaign-finance/
} 
politics played some role in the election campaign. Regularly news articles in the mainstream media focus on what Trump tweets. Some argue that we live in an age of post-truth, where not facts, themes and debate, but ideology, personalities and emotions shape politics. Increasingly, what is highly visible and emotionally attractive is considered as truth.

The post-truth regime means distrust in experts and established politicians and the replacement of arguments and evidence by pure ideology. "I, for one, am not interested in defending a system that for decades has served the interest of political parties at the expense of the people. Members of the club - the consultants, the pollsters, the politicians, the pundits and the special interests - grow rich and powerful while the American people grow poorer and more isolated. [...] The only antidote to decades of ruinous rule by a small handful of elites is a bold infusion of popular will. On every major issue affecting this country, the people are right and the governing elite are wrong. The elites are wrong on taxes, on the size of government, on trade, on immigration, on foreign policy" (Trump 2016c). In the Brexit campaign, Conservative politician and then Secretary of State for Justice Michael Gove said: "I think the people in this country have had enough of experts with organisations with acronyms saying that they know what is best and get it consistently wrong"66. In the 2017 Austrian presidential election, right-wing candidate Norbert Hofer said about Green Party candidate Alexander Van der Bellen: "There is a big difference between the two of us: You have the high society behind you, and I have the people behind me. And that's the big difference"67 (see Fuchs 2016a and 2016c for a more detailed discussion of the 2016 Austrian presidential election's political context and the use of social media in it). All three statements have in common that they construct a conspiratorial rule of the people by established politicians and intellectual and call for antiintellectual politics that are driven by emotions and right-wing ideology. We know today that in the case of Trump the call for an anti-elitist revolution just resulted in the installation of members of the billionaire class as political elite.

A study by Pablo Barberá (2015) analysed 15 million tweets mentioning Obama and Romney during the 2012 US presidential election: "85\% of retweet interactions take place among Twitter users with similar ideological positions. [...] Political polarization is particularly intense among right-leaning Twitter users, as indicated by the darker shading. Although liberal users also present this pattern, they tend to engage more often in conversations all along the ideological spectrum" (Barberá 2015, 87).

Barberá's study seems to confirm that Twitter communication takes place in echochambers, where users listen to, follow, like and re-tweet like-minded political points of view. The study also found that especially right-wingers are intolerant of positions and people who do not share their opinions. The lack of debate and engagement is also expresses as online harassment, ideological violence and anonymous threats. In addition, the fast speed of Twitter also discourages debate.

Trump uses Twitter's brevity of 140 characters for a politics that does not rely on arguments, but on negative emotions that he tries to stir among his followers. Twitter is the best-suited medium for the emotional and ideological politics of outrage, scapegoating, hatred, and attack because its ephemerality, brevity and speed support spectacles and sensationalism. At the same time, the custom of liking and re-

\footnotetext{
${ }^{66}$ https://www.youtube.com/watch?v=GGgiGtJk7MA

67 Translation from German (CF), Original: "Es gibt einen großen Unterschied zwischen uns beiden: Sie haben die Hautvolee und ich hab die Menschen. Und das ist der große Unterschied", https://www.youtube.com/watch?v=YA-OHUDAXrl
} 
tweeting on Twitter appeals to Trump's narcissistic side so that he enjoys his status as a celebrity, brand and political leader.

Wilhelm Reich (1972) argues that authoritarianism not just has political-economic, but also ideological and psychological foundations. Reich was especially interested in the question how authoritarian operates with emotional, unconscious and irrational elements and why it does so successfully. "Every form of totalitarian-authoritarian rulership is based on the irrationalism inculcated in masses of people" (Reich 1972, 312). Reich shows how authoritarianism operates upon "the emotions of the individuals in the masses" and avoided "relevant arguments as much as possible" (Reich $1972,34)$. "Hitler repeatedly stressed that one could not get at the masses with arguments, proofs, and knowledge, but only with feelings and beliefs" (Reich 1972, 83). Twitter is a medium that supports politics that are based on feelings, beliefs and irrationality instead of arguments, proofs and knowledge. Donald Trump has made emotionally laden ideological Twitter politics a key element of his political strategy.

Club 2 was a television debate format broadcast by the Austrian Broadcasting Corporation ORF from 1976 until 1995. After Dark was its British equivalent. Its principles included live, open-ended, uncensored television discussion, controversial topics, invitation of 4-8 participations, a diversity of guests (including non-experts) who often held contradictory points of view, rotating hosts, leather couches and a coffee table, floor lamps, a dark studio, and no studio audience. Disagreeing positions could meet in a neutral space and got enough time for exchanging points of view. In the age of Trump, Twitter and reality TV, political communication is accelerated, very fast and superficial. There is no time and no space for substantial debates. What we need in order to save democracy is not just slow media, but also Club 2.0.

Trump makes use of Twitter for broadcasting 140 character soundbites about what he likes and dislikes. Some examples.

Examples of Trump's Twitter-likes:

- "Vladimir Putin said today about Hillary and Dems: 'In my opinion, it is humiliating. One must be able to lose with dignity.' So true!", December 23, 2016

- "Yes, it is true - Carlos Slim, the great businessman from Mexico, called me about getting together for a meeting. We met, HE IS A GREAT GUY!", December 20, 2016

- “@BillGates and @JimBrownNFL32 in my Trump Tower office yesterday- two great guys!", December 14, 2016

- "The thing I like best about Rex Tillerson is that he has vast experience at dealing successfully with all types of foreign governments.", December 13, 2016

- "I have chosen one of the truly great business leaders of the world, Rex Tillerson, Chairman and CEO of ExxonMobil, to be Secretary of State.", December 13, 2016

- "Will be interviewed on @FoxNews at 10:00 P.M. Enjoy!", December 11, 2016

- “@TigerWoods: Can't wait to get back out there and mix it up with the boys. -TW \#heroworldchallenge" Great to have you back Tiger - Special!", December 3, 2016

- "The President of Taiwan CALLED ME today to wish me congratulations on winning the Presidency. Thank you!", December 2, 2016

- "I am seriously considering Dr. Ben Carson as the head of HUD. I've gotten to know him well--he's a greatly talented person who loves people!", November 22, 2016

- "Many people would like to see @Nigel_Farage represent Great Britain as their Ambassador to the United States. He would do a great job!", November 21, 2016 
- "General James 'Mad Dog' Mattis, who is being considered for Secretary of Defense, was very impressive yesterday. A true General's General!", November 20, 2016

- "Jeb Bush, George W and George H.W. all called to express their best wishes on the win. Very nice!", November 13, 2016

- "Mitt Romney called to congratulate me on the win. Very nice!", November 13, 2016

Examples of Trump's Twitter-dislikes:

- Civil rights activist and House of Representatives member John Lewis was one of the leaders of the 1963 March on Washington. He testified in the US Senate on Donald Trump's decision to nominate Senator Jeff Sessions' for attorney general: 'It doesn't matter whether Sen. Sessions may smile or how friendly he may be, whether he may speak to you. We need someone who will stand up and speak up and speak out for the people who need help, for people who are being discriminated against" ${ }^{\prime 8}$. In an interview, Lewis said he did not consider Trump as a legitimate president and that "the Russians participated in helping this man get elected" (Todd, Bronston and Rivera 2017).

Trump commented on Twitter: "Congressman John Lewis should spend more time on fixing and helping his district, which is in horrible shape and falling apart (not to mention crime infested) rather than falsely complaining about the election results. All talk, talk, talk - no action or results. Sad!", January 14, 2017.

- After CNN had reported on an alleged Russian dossier on Trump, Trump attacked the channel in a press conference and wrote on Twitter: “@CNN is in a total meltdown with their FAKE NEWS because their ratings are tanking since election and their credibility will soon be gone!", January 12, 2016.

- “@NBCNews purposely left out this part of my nuclear quote: 'until such time as the world comes to its senses regarding nukes.' Dishonest!”, December 23, 2016

- "If Russia, or some other entity, was hacking, why did the White House wait so long to act? Why did they only complain after Hillary lost?", December 15, 2016

- "The media tries so hard to make my move to the White House, as it pertains to my business, so complex - when actually it isn't!", December 15, 2016

- "Has anyone looked at the really poor numbers of @VanityFair Magazine. Way down, big trouble, dead! Graydon Carter, no talent, will be out!", December 15, 2016

- “Just watched @NBCNightlyNews - So biased, inaccurate and bad, point after point. Just can't get much worse, although @CNN is right up there!”, December 11,2016

- "Chuck Jones, who is President of United Steelworkers 1999, has done a terrible job representing workers. No wonder companies flee country!", December 7, 2016

- "Boeing is building a brand new 747 Air Force One for future presidents, but costs are out of control, more than \$4 billion. Cancel order!", December 6, 2016

- "If the press would cover me accurately \& honorably, I would have far less reason to 'tweet.' Sadly, I don't know if that will ever happen!", December 5, 2016

- "The Green Party just dropped its recount suit in Pennsylvania and is losing votes in Wisconsin recount. Just a Stein scam to raise money!", December 4, 2016

${ }^{68}$ http://politics.blog.ajc.com/2017/01/11/read-john-lewis-full-testimony-against-jeff-sessions/ 
- "Just tried watching Saturday Night Live - unwatchable! Totally biased, not funny and the Baldwin impersonation just can't get any worse. Sad", December 3, 2016

- "I thought that @CNN would get better after they failed so badly in their support of Hillary Clinton however, since election, they are worse!", November 29, 2016

- "@CNN is so embarrassed by their total (100\%) support of Hillary Clinton, and yet her loss in a landslide, that they don't know what to do.", November 28, 2016

- "If Cuba is unwilling to make a better deal for the Cuban people, the Cuban/American people and the U.S. as a whole, I will terminate deal.", November 28, 2016

- "The Green Party scam to fill up their coffers by asking for impossible recounts is now being joined by the badly defeated \& demoralized Dems", November 26, 2016

- "Fidel Castro is dead!", November 26, 2016

- "The failing @nytimes just announced that complaints about them are at a 15 year high. I can fully understand that - but why announce?", November 22, 2016

- "Perhaps a new meeting will be set up with the @nytimes. In the meantime they continue to cover me inaccurately and with a nasty tone!", November 22, 2016

- "I cancelled today's meeting with the failing @nytimes when the terms and conditions of the meeting were changed at the last moment. Not nice", November 22, 2016

- "I watched parts of @nbcsnl Saturday Night Live last night. It is a totally one-sided, biased show - nothing funny at all. Equal time for us?", November 20, 2016

- "The cast and producers of Hamilton, which I hear is highly overrated, should immediately apologize to Mike Pence for their terrible behaviour", November 20, 2016

- "The Theater must always be a safe and special place. The cast of Hamilton was very rude last night to a very good man, Mike Pence. Apologize!", November 19, 2016

- "Our wonderful future V.P. Mike Pence was harassed last night at the theater by the cast of Hamilton, cameras blazing. This should not happen!", November 19, 2016

- "The failing @nytimes story is so totally wrong on transition. It is going so smoothly. Also, I have spoken to many foreign leaders.", November 16, 2016

- "The @nytimes sent a letter to their subscribers apologizing for their BAD coverage of me. I wonder if it will change - doubt it?", November 13, 2016

- "Wow, the @nytimes is losing thousands of subscribers because of their very poor and highly inaccurate coverage of the 'Trump phenomena'”, November 13, 2016

Trump's Twitter-politics is a politics of 140 character soundbites that consist of a world polarised into friends and enemies. Via Twitter, Trump broadcasts news about how his personal friend/enemy-scheme evolves. There are two sides: The side of the friends, whom he characterises as great, impressive, nice, successful, and talented. And the side of the enemies, whom he characterises as bad, biased, failing, inaccurate, dishonest, nasty, not nice, one-sided, overrated, poor, rude, sad, terrible, untalented, or wrong. Trump's politics is a world of polar opposites, in which representatives of the two sides have completely opposed characteristics.

Data scientists conducted a quantitative analysis of Trump's tweets. They found that Trump tends to use language that is negative and scapegoats: "But what's truly distinctive is how he uses adjectives: He combines an adjective followed by someone's name a stunning 10 times more than any other candidate. This is primarily be- 
cause of his proclivity for using Twitter to launch personal attacks on specific individuals, like 'lightweight' Megyn Kelly, 'little' Marco Rubio, 'low-energy' Jeb Bush, 'dopey' Bill Kristol, etc. [...] Trump is also distinctive in his use of pronouns ('I,' 'you,' 'he,' 'she,' 'we,' 'us,' etc.). Trump uses pronouns in a very different way than the other candidates. 'I' and 'me' (as well as Trump's own name) are used much more than other candidates. While @realDonaldTrump's use of 'we' is within the range of other candidates', Trump hardly uses the pronoun 'us' - a bit surprising for a presidential candidate who is expected to lead America to a 'great' shared future" (Tsur, Ognyanova and Lazer 2016).

For Trump, Twitter is a symbolic and communicative battlefield. Carl Schmitt characterised such a worldview as the friend/enemy-scheme:

The specific political distinction to which political actions and motives can be reduced is that between friend and enemy [...] Insofar as it is not derived from other criteria, the antithesis of friend and enemy corresponds to the relatively independent criteria of other antitheses: good and evil in the moral sphere, beautiful and ugly in the aesthetic sphere, and so on. [...] The distinction of friend and enemy denotes the utmost degree of intensity of a union or separation, of an association or dissociation. [...] Emotionally the enemy is easily treated as being evil and ugly, because every distinction, most of all the political, as the strongest and most intense of the distinctions and categorizations, draws upon other distinctions for support. [...] The enemy is solely the public enemy, because everything that has a relationship to such a collectivity of men, particularly to a whole nation, becomes public by virtue of such a relationship. [...] War follows from enmity. War is the existential negation of the enemy. It is the most extreme consequence of enmity. It does not have to be common, normal, something ideal, or desirable. But it must nevertheless remain a real possibility for as long as the concept of the enemy remains valid (Schmitt 1932/1996, 26, 27, 28, 33).

For Trump, Twitter is a symbolic and communicative battlefield. Trump calls social media his "method of fighting back": "It's a great form of communication. [...] I think I picked up yesterday 100,000 people. I'm not saying I love it, but it does get the word out. When you give me a bad story or when you give me an inaccurate story or when somebody other than you and another network, or whatever, 'cause of course, CBS would never do a thing like that right? I have a method of fighting back. That's very tough. [...] I really believe that the fact that I have such power in terms of numbers with Facebook, Twitter, Instagram, et cetera, I think it helped me win all of these races where they're spending much more money than I spent"69.

Besides Twitter, also television is a very important communication medium for Trump. The first television debate between Trump and Clinton reached a total of 84 million US viewers, including 18 million viewers on NBC, 13.5 million on ABC, 12.1 million on CBS, 11.4 million on Fox News, 9.9 million on CNN, 5.5 million on the Fox network channels, 4.9 million on MSNBC, 2.5 million on Univision, and 1.8 million on Telemundo (Stelter 2016). The debate attracted the largest audience ever reached in sixty years of televised US presidential debates. "In November, Fox averaged 3.3 million viewers in primetime, a 68\% increase over November 2015. CNN averaged

\footnotetext{
${ }^{69}$ https://www.scribd.com/document/330970776/Trump-60-Minutes2\#download\&from embed
} 
1.5 million viewers, a $128 \%$ increase from last November. MSNBC attracted 1.3 million viewers, a 98\% increase. [...] Strong ratings have translated into solid profits and revenues. Ad revenue for cable news may reach $\$ 2$ billion this year, a $15 \%$ increase over 2015. Media analytics company SNL Kagan predicts record-breaking profits of $\$ 1.67$ billion for Fox News and nearly \$1 billion for CNN“ (Edkins 2016). The New York Times saw its paid subscriptions increasing by 132,000 during a three-week period in November 2016, a growth rate ten times higher than during the same period in 2015 (Belvedere 2016).

In the world of the capitalist spectacle, the capitalist media need Trump just like Trump needs the media. The mainstream media helped making Trump both economically and politically. A truly critical strategy would be to provide no free promotion to Trump by ignoring him. To say nothing, report nothing, and comment on nothing that is right-wing populist in character has to be part of breaking the right-wing spectacle's spell. According to a report, NBC, CBS and ABC gave 23.4 times more coverage to Trump than to Sanders (Boehlert 2016). An alternative strategy also requires changing the balance of forces in media coverage.

\subsection{The Apprentice: Trumpology as Reality TV Spectacle}

The Apprentice is a reality TV-show broadcast by NBC. It featured Donald Trump as host and juror from 2004 until 2015. The concept of the show involves a group of participants who want to become successful entrepreneurs and learn from Trump. They compete against each other by performing business tasks. Each week, Trump eliminates at least one with the words "You're fired". In 2008, NBC also introduced the show The Celebrity Apprentice, in which celebrities participate. Trump created the media company Trump Productions for producing these shows.

"Why do you think NBC gave me my own show, The Apprentice? They did it because I set myself apart to be a target, the big, tough employer. The result was one of the most successful shows in television history. I'm the only boss in the world who boosts a person's future status by firing them" (Trump 2015a, 12). Trump's image as combative leader and tough businessman drove audience ratings. More than 40 million viewers watched the first season's finale in 2004 (Carter 2004).

NBC not just paid Trump for hosting The Apprentice, the show was also an opportunity for Trump to present and sell himself as brand. "Donald Trump built his reputation selling real estate, but the thing he had always wanted to sell was Donald Trump. His career as a reality television star would finally make Trump into a household brand - and he was determined to cash in. [...] Trump Menswear made an appearance, of course, on an episode of The Apprentice. So did Trump Ice, a new brand of water, and Trump Success, a new fragrance. Riding the popularity of the show, Trump licensed his name to clothes, ties, home furnishings, eyeglasses, wallets, even mattresses" (Kranish and Fisher 2016, 221, 224).

I have analysed a large sample of 201 elimination scenes from The Apprentice's first fourteen seasons (2004-2015) by conducting a content analysis of the scenes in the boardroom. The analysis focused on how Trump justifies the elimination of candidates. Table 8 shows the results. The reasons for firing are summarised as ideal types.

The analysis shows that the justifications that Trump used most frequently for eliminated contestants were that they in his opinion showed poor leadership or performed poorly. The third most frequent elimination reason was that Trump thought candidates were weak and emotional. Taking these aspects together, it becomes clear that Trump in The Apprentice imagines a good businessperson to be a strong 
and hierarchic leader, who works hard, achieves high performance measured in terms of success and profits, shows no weaknesses, and is tough and ruthless.

\begin{tabular}{|c|c|c|c|}
\hline Reason for firing & $\begin{array}{l}\text { Absolute } \\
\text { frequency }\end{array}$ & $\begin{array}{l}\text { Relative fre- } \\
\text { quency }\end{array}$ & Example justifications \\
\hline $\begin{array}{l}\text { "You have no } \\
\text { leadership capaci- } \\
\text { ties!" }\end{array}$ & 95 & $47.3 \%$ & $\begin{array}{l}\text { "A stupid, impulsive, life-threatening decision. Frankly, if you are } \\
\text { running a company and make that kind of decision, you destroy } \\
\text { that company instantaneously" (S2E2) } \\
\text { "You wouldn't step up us a leader" (S1E10) } \\
\text { "I just don't think that you are a strong leader" (S3E11) } \\
\text { "You were the team leader. The team was a mess. The project } \\
\text { was no good. And Chris, you are fired" (S3E12). } \\
\text { "Your decision making was terrible" (S4E6) } \\
\text { "Lenny made a lot of mistakes. Lenny was not a good leader for } \\
\text { this team. [...] The leadership wasn't good" (S5E7) } \\
\text { "You're not a proper leader. Amy, you're fired!" (S6E1) } \\
\text { "You did a lousy job and you're a bad project manager" (S6E7) } \\
\text { "But the concept was flawed and you were the project manager. } \\
\text { You got killed" (S6E11) } \\
\text { "You couldn't control him. You brought in no money. And you } \\
\text { had a lousy looking store. You were not much of a team leader. } \\
\text { [...] You are fired! You were lousy last week, lousy this week. } \\
\text { We have to do it. Go!" (S8E3) }\end{array}$ \\
\hline $\begin{array}{l}\text { "Your performance } \\
\text { was poor!" }\end{array}$ & 73 & $36.3 \%$ & $\begin{array}{l}\text { "You lose! I do not want to take a chance on somebody who } \\
\text { loses all the time perhaps" (S2E13) } \\
\text { "Everybody virtually said you just did not contribute, you were } \\
\text { not a go-getter" (S2E1) } \\
\text { "You are totally ineffective. You have done a terrible job" (S4E4) } \\
\text { "You didn't sell. You failed" (S4E6) } \\
\text { "You did not do much" (S4E7) } \\
\text { "No matter which team you are on, all you do is create problems" } \\
\text { (S4E9) } \\
\text { "That suit is a loser. On this task, you did a horrible job!" (S6E2) } \\
\text { "Alex sold the least. And Alex just does not seem to have the } \\
\text { same passion as you two guys. Alex, you are fired!" (S10E2) } \\
\text { "He raised no money. Gotta do it. Richard, you are fired!" } \\
\text { (S11E5) } \\
\text { "Deborah raised the least money of the people you brought } \\
\text { back. Deborah, you are fired!" (S12E7) }\end{array}$ \\
\hline $\begin{array}{l}\text { "You are no fight- } \\
\text { er. You are not } \\
\text { tough. You are } \\
\text { weak" }\end{array}$ & 11 & $5.5 \%$ & $\begin{array}{l}\text { "I hated the way you took so much crap [...] To me that was a } \\
\text { form of weakness" (S1E6) } \\
\text { "You did not fight for yourself and you are fired" (S1E5) } \\
\text { "You are not strong enough to be here, you are just not strong- } \\
\text { enough" (S4E12) } \\
\text { "It was just too much emotion [...] From a pure business point of } \\
\text { view, too much emotion can also be not so good. And therefore, } \\
\text { Meat Loaf, you are fired!" (S11E11) }\end{array}$ \\
\hline $\begin{array}{l}\text { "You were disloyal } \\
\text { to your team" }\end{array}$ & 9 & $4.5 \%$ & $\begin{array}{l}\text { "You lashed out at your project leader, which was completely out } \\
\text { of line" (S2E11) } \\
\text { "What I hate is that Stacey keeps going on about responsibility, } \\
\text { how it is never your fault. You never take responsibility. [...] You } \\
\text { can't just blame the project manager when you are unsuccessful } \\
\text { getting your point across" (S2E7) } \\
\text { "Every single woman in this room thought you were a disruptive } \\
\text { force" (S4E1) } \\
\text { "Most importantly, there was a great disloyalty to your team. Lou, } \\
\text { you are fired!" (S12E8) }\end{array}$ \\
\hline Candidate quits & 6 & $3.0 \%$ & \\
\hline $\begin{array}{l}\text { "Your behaviour is } \\
\text { unpredictable" }\end{array}$ & 4 & $2.0 \%$ & "I just can't have a loose cannon on my hands" (S2E3) \\
\hline $\begin{array}{l}\text { "The others do not } \\
\text { like you" }\end{array}$ & 1 & $0.5 \%$ & "Your teammates did not really like you too much" (S2E15) \\
\hline $\begin{array}{l}\text { "The others are } \\
\text { more exciting than } \\
\text { you are" }\end{array}$ & 1 & $0.5 \%$ & \\
\hline Cheating & 1 & $0.5 \%$ & \\
\hline
\end{tabular}

Table 8: Frequency of Donald Trump's justifications for the elimination of participants in The Apprentice (2004-2015), N=201

The ideal manager and worker as portrayed in "The Apprentice" is a person who shows all features of Trumpology: possessive individualism, performance and hard 
labour, top-down leadership, and the belief in survival of the fittest and cut-throat competition (Social Darwinism).

In the boardroom scenes, Trump often uses very negatively laden terms that can have humiliating effects on those whom he eliminates. Typical examples are "stupid", "mess", "terrible", "mistakes", "not good", "lousy", "bad", "flawed", "losing", "failing", "ineffective", "loser", "horrible", "weakness", "not strong enough", "too much emotion", "unsuccessful", "disruptive". Such terms set up a clear binary between tough, successful, hard-working winners and weak, unsuccessful, lazy losers. The Apprentice conveys a picture of society as consisting only of winners and losers with nothing in between. The winners are presented as strong and tough like warriors in an army. The soldier is the ultimate role model, on which Trumpology and The Apprentice are built. There is also a patriarchal dimension that uses dualisms such as strong/weak, rational/emotional, the leaders/the led. The model of the warrior always implies the possibility for war, which is present in the dimension of cutthroat competition.

Survival of the fittest, hierarchy and performance measurement in The Apprentice imply that you have to make profits in order to be a winner. Those who are blamed for poor financial performance are therefore often eliminated: "You brought in no money", "You didn't sell. You failed", "He sold the least", "He raised no money", "She raised the least money". The unity of leadership, possessive individualism, performance measurement and Social Darwinism is ideologically and socially aimed at the accumulation of money and power.

Academic literature studying The Apprentice has stressed several aspects:

1. Individualism:

"The world of The Apprentice is based around an extreme individualism, where everyone is a master of his (or her) own destiny, to the detriment of all others. Trump frequently describes the - from selling candy bars to constructing ad campaigns - as military operations" (Franko 2006, 255).

"The participants represent models of conduct, to be approved or disapproved according to extant ideological criteria of 'the American dream', which involves the prospect of individual ascent to the top irrespective of social background, and correct 'enterprising' business practice under neoliberal conditions" (McGuigan 2008, 310-311).

2. The ideology of hard labour:

"By presenting the 'reality' of work and business in the form of highly structured entertainment, The Apprentice transforms the norms of the neoliberal workplace into taken-for-granted 'common sense'” (Couldry and Littler 2011, 265).

The "highly distinctive performance norms of neoliberal business culture are themselves naturalized and objectified as part of 'the real world out there' [...] neoliberal norms are reified as 'rules of the game"' (Couldry and Littler 2011, 275).

3. Leadership:

"Trump himself acts, without any irony, as the semi-autocratic ruler and the ultimate CEO" (Franko 2006, 248).

4. Social Darwinism:

"The Apprentice is imbued with market values and seeks to validate the absolute worth of capitalist business whatever the human cost most obviously the arduous testing of candidates in the show in order to reveal the fittest" (McGuigan 2008, 318). 
The Apprentice poses questions about the relationship of play/labour, the real/the symbolic, co-operation/competition, consciousness/the unconscious, the real/the imaginary, and the real/the ideological. It is a game, in which real world participants perform labour as play. It is an artificial, mediated and symbolic game that is a manifestation of neoliberal capitalism's reality. It features co-operation for the sake of competition so that feelings of solidarity are subsumed under the logic of individual survival and competition. The show allows the audience to project their desires of success and their actual experiences of stress and hardship into the candidates and Donald Trump as leader. This projection involves both love and aggression towards particular successful and unsuccessful participants and Trump's success, behaviour and aggression.

The Apprentice's competition between winners and losers is a mediated sociopsychological spectacle and drama that appeals to viewers' unconscious desires, fantasies and drives. The real and the imaginary life of both participants and viewers meet in the programme's symbolic world that is broadcast into everyday people's homes. But given the way the programme is constructed around cutthroat competition, hyper-individualism, elimination, and the ruthless firing and humiliation of the least successful, The Apprentice's socio-psychological structure has a predominantly instrumental and ideological character. It hails the viewers as neoliberal subjects and tries to teach them neoliberal militancy and neoliberalism as philosophy of life. The Apprentice portrays reality in its neoliberal version and tries to implement this image as normal reality. It is of course not certain to which extent this instrumental project is successful because audiences are complex. But we can say that the ideological dimension is the key feature of The Apprentice.

The Apprentice sets up an extremely polarised vision of society - a world, in which there is just one winner and all others are losers, who are on their own, are eliminated, crushed and for whom there is no mercy, solidarity or support. The Apprentice envisions a world of untamed, pure capitalism without a welfare state and without solidarity. It is a world without elements of socialism. It is an unsocial world, an inhumane society. The Apprentice is not just a TV show, but also an ideological project that tries to normalise pure capitalism.

The analysis shows that hyper-individualism, the ideology of performance and hard labour, top-down leadership, and Social Darwinism along with the friend/enemy distinction form key elements of Trumpology. The Apprentice reflects the elements of this ideology in a game show that tries to normalise and justify pure capitalism that lacks any elements of solidarity and social security. Imagine a society, whose political system is guided by the vision advanced by Trumpology and The Apprentice. In such a society, large parts of the welfare state and public services are privatised. It is an autocratic society that is governed top-down with limited possibilities for opposition. Law and order politics impose harsh sentences even for minor crimes. It is a highly armed and militarised society threatening to use its repressive capacities against perceived enemies. Corporate taxation is low or non-existent. Workers' rights hardly exist. There is no minimum wage regulation. Trade unions have no influence on working conditions. There close ties between big capital and the state that advances monopoly capital's interests. Culture is unitary and closed and based on a strict dichotomy of the nation and the foreign.

Ideologies always have real and fictitious dimensions. It is not predetermined how close or distant a society governed by Donald Trump as President will come to Trumpology's dystopia. The decisive question will be to which extent Trump wants to 
and can realise elements of Trumpology in actual politics. This will depend on the question to which degree his policies will be guided by Trumpology and resisted by internal (within the Republican Party) and external forces (parliamentary opposition, civil society). In newspapers and on The Apprentice, Twitter and television shows, Trumpology presents itself in a quite frightening way. A key question is to which degree President Trump will put ideology into policy, words into action, and to which degree he will keep up, radicalise or moderate Trumpology's economic, political and ideological dimensions.

\section{Conclusion: Towards a Critical Theory of Contemporary Authoritarianism, Trumpology and Trumpism}

In critical theory, the leadership principle, nationalism, the friend/enemy scheme, and patriarchy are seen as four important feature of authoritarianism.

The leadership principle is a first important element of authoritarianism. Theodor W. Adorno argues that an authoritarian leader "characteristically indulges in loquacious statements about himself" (Adorno 1975, 11). We have seen in the analysis presented in this paper that Trumpism and Trumpology are all about Trump as brand, business leader and political leader. Trump's politics and ideology are completely centred on himself. The reason why this strategy has made him American president may be that the personality cult and the identification with one person as leader responds to the "coldness, [...] despair, isolation, and loneliness" (11) under which individuals suffer. "The more impersonal our order becomes, the more important personality becomes as an ideology. The more the individual is reduced to a mere cog, the more the idea of the uniqueness of the individual, his autonomy and importance, has to be stressed as a compensation for his actual weakness" (11-12). Trump's followers project their frustrations into Trump as symbol of their longing for love and hope. The follower, "by making the leader his ideal [...] loves himself, as it were, but gets rid of the stains of frustration and discontent which mar his picture of his own empirical self" (Adorno 1991, 140). There is "identification through idealization" (140).

The leader often presents himself as a lone wolf fighting against political elites (Adorno 1975, 14). This comes along with "aversion to the professional politician and perhaps to any kind of expertness" (21). We have seen that Trump opposed the established political elites in the Democratic Party and the Republican Party. He cultivates the image of a lone wolf, who is a self-made billionaire and self-made president opposing career politicians. He presents himself as the prototypical winner of the American Dream, who by hard labour has made it to the top. The message to everyday Americans is, "If I can make it to the top, then you can do so too!". Authoritarianism perpetuates "actually and ideologically the necessity of hard work, this obtaining a justification for 'discipline' and oppression" (Adorno 1975, 23).

Trump's populist, aggressive, attack-oriented, offensive, proletarian language and style make him appear as a great little man, who is on the top, but at the same time an ordinary person. The great little man is "a person who suggests both omnipotence and the idea that he is just one of the folks" (Adorno 1991, 142). "While appearing as superman, the leader must at the same time work the miracle of appearing as an average person" (141). The great little man "walks unrecognized in the same paths as other folks, but [...] finally is to be revealed as the saviour" (Adorno 1975, 29)

Nationalism is a second feature of authoritarianism. Demagogues try to create an artificial bond (Adorno 1991, 135) such as the nation. They use what Adorno calls the unity trick: They argue that everyone, except outsiders, is part of the nation and that 
out-groups are threatening this unity. They make use of the logic of repressive egalitarianism (Adorno 1991, 146). "They emphasize their being different from the outsider but play down such differences within their own group and tend to level out distinctive qualities among themselves with the exception of the hierarchical one" (146). They aim at "the establishment of something utterly limited and particularistic as the totality, the whole, the community" (Adorno 1975, 58). We have seen that Trump argues that he will make "America great again". He promises prosperity, wealth, and worldwide recognition to American citizens. But he can do so only by constructing enemy out-groups that are seen as damaging the greatness of the American nation. By playing with nationalism, Trump detracts attention from the actual class differences within the United States.

Authoritarianism as its third feature makes use of the friend-enemy scheme. Nationalist unity always has an outside that is portrayed as enemy: "the Communists, the radicals, the sceptics, and, of course, the Jews. These groups are a priori exempted from such a unity; they merely threaten it and must be "driven away"' (Adorno $1975,59-60)$. The imagined unity is one of the "right people" (60). Right-wing demagogues "cannot help feeling surrounded by traitors, and so continuously threatens to exterminate them" (Adorno 1975, 78). Erich Fromm (1936) characterises the authoritarian personality as sadomasochistic character type that feels pleasure in both submission to authority and the subjection of underdogs. Authoritarian societies would foster sadomasochistic personalities (117-118) Authoritarian personalities therefore show "aggression against the defenceless and sympathy for the powerful" (115). Authoritarianism has an extremely polarised relationship to the powerful and the weak: "To the one group all good characteristics are ascribed and they are loved, and to the other group all negative characteristics are ascribed and they are hated" (116). Authorities would often support and promote this dual structure in order to reach the double goal of on the one hand keeping the relationship to one group "free from hatred and directing on the other hand hatred against forces that it wants to combat with the help of the subaltern" (116).

Trump constructs out-groups such as illegal immigrants, Mexico, China, Muslims, oppositional politicians, and his critics. They are presented as threatening the greatness of the American nation. According to Adorno, identification with the leader and hatred against the out-group allows emotional release (Adorno 1975, 16-20). Such a release of aggression encourages "excess and violence" (17).

Patriarchy plays a peculiar role in authoritarianism as its fourth feature. On the one hand, the male warrior, who fights and does not show emotions, is presented as the ideal human being that should be imitated. The "model of the military officer" is "transferred to the realm of politics" (Adorno 1975, 49). Love to the leader is an "emotional compensation for the cold, self-alienated life of most people" (Adorno 1975, 37). We have seen that in Trump's world, survival, toughness, strength, and the willingness to fight, lead and compete are moral norms. The "reference to love is almost completely excluded" (Adorno 1991, 137). The "traditional role of the loving father" is replaced "by the negative one of threatening authority" (Adorno 1991, 137).

But at the same time love to the leader is a psychological factor that allows followers to project their fears into the leader and hope for compensation. The leader stands for "an omnipotent and unbridled father figure" (Adorno 1991, 139). Identification is the psychological expression of an emotional tie between the leader and a community that accepts this leadership (139). So whereas love is on the one hand excluded from politics and relegated to the realm of the family, it at the same time plays a key role in the identification with the leader that is love for the leader and at 
the same time the compensation for the fear of not feeling loved by and accepted in society. "The desire to be loved, no matter if it is more or less conscious, and the fear of loss even just of the possibility to be loved are the basis for admiration and obedience" (Fromm 1936, 78).

Franz Neumann $(1957,288-293)$ argues that political change in a specific direction can occur under the condition of the alienation of labour, destructive competition and political alienation. If such objective conditions are translated into feelings of social alienation, i.e. the collective fear by a group that "its prestige, income, or even its existence" (290) could decline, then such change becomes more likely. Neumann also adds that in such situations, institutionalised forms of anxiety such as demagogic leaders, movements and parties often bring about the transition from objective conditions and subjective anxiety into political action and change.

This paper has shown that the conditions of American capitalism have featured relative wage decreases resulting in the increase of capital in total wealth, costly technological progress, fluctuating profit rates that have spurred financialisation, capital export and de-industrialisation in an international division of labour. Political alienation, i.e. the structural feeling that politicians do not represent everyday citizens, came along with the rising power of capital. In this situation, right-wing populists have institutionalised anxiety by spurring nationalism and resentments against immigrants, refugees, Muslim, and their opponents and critics. This means that scapegoats have become the subject of aggression and projected fears. The political trick is that ideology deflects attention from the role of class and capitalism in the creation of social problems. The paradoxical effect is that working class voters elect a billionaire as president who represents the political interest of capital because the national interest is foregrounded against imagined enemies so that the class conflict is ideologically made invisible, although it continues to exist.

Table 9 summarises dimensions of how the state and politics could look like under Trump's rule.

That a billionaire turns president means a significant change in the relationship between the state and the economy. Big capital has more opportunities to rule directly. The government that Trump appointed indicates the tendency of an overlap between the political elite and the capitalist class. One has to wait and see what this means in terms of concrete economic policies. The ideological and political signs certainly point towards an even purer and untamed capitalism than before. A key question is how the realm of oppositional politics and civil liberties will develop under Trump. His political rhetoric in the election campaign and the elements of Trumpology have raised fears of what may happen. Threats to civil liberties pose in general a potential for the rise of authoritarian statism.

Trumpism is not just a brand, a business strategy and a political strategy. Trump is also Trumpology, an ideology that stages itself as spectacle in public and in the media. Trumpology involves elements such as possessive individualism, the Ideology of hard labour, performance measurements, hierarchic leadership, survival of the fittest, and cutthroat competition. 


\begin{tabular}{|c|c|}
\hline Dimension & $\begin{array}{l}\text { Possible Elements of the State and Politics under } \\
\text { Trump }\end{array}$ \\
\hline $\begin{array}{l}\text { Relationship of the } \\
\text { state to the economy }\end{array}$ & $\begin{array}{l}\text { Overlap of the political elite and the capitalist class in the } \\
\text { form of a politician-turned-billionaire. There is a tendency } \\
\text { for the blurring of the boundaries between the state and big } \\
\text { capital. } \\
\text { Economic policies: } \\
\text { - Low-tax economy with massive tax reductions for corpo- } \\
\text { rations and the rich } \\
\text { - Protectionism (e.g. tariffs) and de-globalisation of the US } \\
\text { economy. } \\
\text { - State intervention in favour of big capital (oil/gas/coal in- } \\
\text { dustry, health care and pharmaceutical industry, private } \\
\text { education, construction, etc.) } \\
\text { - Private-public partnerships in infrastructure projects fea- } \\
\text { turing socialised financial risk and private ownership. } \\
\text { - Logic of privatisation and for-profit in health care and ed- } \\
\text { ucation }\end{array}$ \\
\hline $\begin{array}{l}\text { State institutions and } \\
\text { the relationship of the } \\
\text { state to citizens to the } \\
\text { state }\end{array}$ & $\begin{array}{l}\text { - Law and order politics } \\
\text { - Close political ties to far-right figures, friend/enemy-logic, } \\
\text { revanchism ("screw them back in spades"), and insults of } \\
\text { opponents have raised fears of authoritarian statism. } \\
\text { - The scapegoating of immigrants and Muslims has raised } \\
\text { fears of authoritarian statism. }\end{array}$ \\
\hline Inter-state relations & $\begin{array}{l}\text { Foreign trade: } \\
\text { - Scepticism of international free trade agreements. } \\
\text { - Scapegoating of other nations for socio-economic prob- } \\
\text { lems in the USA. } \\
\text { Foreign policy: } \\
\text { - Plan to build a wall between the Mexican and the US } \\
\text { border. } \\
\text { - Political distance and hostility towards certain countries } \\
\text { such as China, Mexico, Iran, and Cuba. } \\
\text { - Unilateralism } \\
\text { - Politics of armament } \\
\text { - Friend/enemy-scheme }\end{array}$ \\
\hline Ideology & $\begin{array}{l}\text { Trumpology: } \\
\text { - Possessive individualism } \\
\text { - Ideology of hard labour and performance measurement } \\
\text { - Hierarchic leadership } \\
\text { - Social Darwinism, survival of the fittest, cutthroat compe- } \\
\text { tition } \\
\text { A key question for the future of the US state and US socie- } \\
\text { ty is to which degree these ideological elements will be } \\
\text { used as discourses by the state and discourses on the } \\
\text { state that are put into political practice. }\end{array}$ \\
\hline
\end{tabular}

Table 9: Dimensions of the state under Trump 
For-profit mainstream media that are often (pseudo-)critical of Trump have helped to make him because they know that making Trump means that Trump makes them: The monetary and reputational profits of Trump and the for-profit mainstream media live in a contested, but happy symbiosis within the capitalism of the spectacle. The only way of overcoming this vicious cycle that has contributed to Trump's political rise would be to slow down the speed of the media (slow media) and to stop giving so much attention to Trump. The media rather would have to give much more attention, space and time to the analysis and discussion of the big contradictions that society faces at the macro-level.

The combination of Trump's actual power and Trump as spectacle, showman and brand makes his government's concrete policies fairly unpredictable. Franz Neumann in the 1950s wrote the essay Anxiety and Politics, in which he reflects on what intellectuals can do in political situations, where they face threats of the rise of authoritarianism. His words sound very topical in the world of 2017. Neumann argues that what remains is

the dual offensive on anxiety an for liberty: that of education and that of politics. Politics, again, should be a dual thing for us: the penetration of the subject matter of our academic discipline with the problems of politics - naturally, not dayto-day politics - and the taking of positions on political questions. If we are serious about the humanization of politics; if we wish to prevent a demagogue from using anxiety and apathy, then we - as teachers and students - must not be silent. We must suppress our arrogance, inertia, and our revulsion from the alleged dirt of day-to-day politics. We must speak and write. [...] Only through our own responsible educational and political activity can the words of idealism become history" (Neumann 1957, 294-295).

\section{References}

Adorno, Theodor W. 1991. The Culture Industry. Abingdon: Routledge.

Adorno, Theodor W. 1975. The Psychological Technique of Martin Luther Thomas' Radio Adresses. In Soziologische Schriften II.1, 11-141. Frankfurt am Main: Suhrkamp.

American Immigration Council. 2015. The Criminalization of Immigration in the United States. https://www.americanimmigrationcouncil.org/sites/default/files/research/the criminalizatio $\mathrm{n}$ of immigration in the united_states.pdf

Anderson, Benedict. 1991. Imagined Communities. Reflections on the Origin and Spread of Nationalism. London: Verso. $2^{\text {nd }}$ edition.

Ashcroft, Michael. 2016. How the United Kingdom Voted on Thursday... And Why. http://lordashcroftpolls.com/2016/06/how-the-united-kingdom-voted-and-why/

Associated Press. 2016. Trump to Nominate Retired Gen. James Mattis to Lead Pentagon. Associated Press Online, December 2, 2016.

Barberá, Pablo. 2015. Birds of the Same Feather Tweet Together: Bayesian Ideal Point Estimation Using Twitter Data. Political Analysis 23 (1): 76-91.

Baxter, Anthony. 2011. You've Been Trumped. Documentary. Montrose: Montrose Pictures.

Belvedere, Matthew J. 2016. New York Times Subscription Growth Soars Tenfold, Adding 132,000, after Trump's Win. CNBC Online, November 29, 2016.

Boccara, Paul. 1982. Studien über „Das Kapital“. Frankfurt am Main: VMB.

Boehlert, Eric. 2015. ABC World News Tonight Has Devoted Less Than One Minute To Bernie Sanders' Campaign This Year. MediaMatters, December 11, 2015. http://mediamatters.org/blog/2015/12/11/abc-world-news-tonight-has-devoted-less-thanon/207428 
Booth, Robert et al. 2016. Breitbart: How "Trump Pravda" Muddied the Waters and Surfed Wave. The Guardian Online, November 14, 2016.

Carrell, Severin. 2016. Donald Trump Faces Wall of Opposition as He Returns to Scotland. The Guardian Online, June 23, 2016.

Carter, Bill. 2004. "The Apprentice" Scores Ratings Near Top for the Season. The New York Times Online, April 17, 2004.

Chomsky, Noam. Trump in the White House: An Interview. Truth Out, November 14, 2016. http://www.truth-out.org/opinion/item/38360-trump-in-the-white-house-an-interview-withnoam-chomsky

Clinton, Hillary and Donald Trump. 2016a. First Presidential Debate. September 26, 2016. https://www.youtube.com/watch?v=855Am6ovK7s

Clinton, Hillary and Donald Trump. 2016b. Second Presidential Debate. October 9, 2016. https://www.youtube.com/watch?v=FRII2SQ0Ueg

Clinton, Hillary and Donald Trump. 2016c. Third Presidential Debate. October 19, 2016. https://www.youtube.com/watch?v=smkyorC5qwc

Cook, Lynn. 2015. What Will the U.S. Energy Industry Look Like Over the Next Five Years? Wall Street Journal Online, November 15, 2015.

Couldry, Nick and Jo Littler. 2011. Work, Power and Performance: Analysis the "Reality" Game of The Apprentice. Cultural Sociology 5 (2): 263-279.

Davenport, Coral and Eric Lipton. 2016. Trump Picks Scott Pruitt, Climate Change Dissenter, to Lead E.P.A. The New York Times Online, December 7, 2016.

Dorocki, Sławomir and Paweł Brzegowy. 2014. The Maquiladora Industry Impact on the Social and Economic Situation in Mexico in the Era of Globalization. In Environmental and Socio-Economic Transformations in Developing Areas as the Effect of Globalization, ed. Mirosław Wójtowicz and Anna Winiarczyk-Raźniak, 93-110. Kraków: Wydawnictwo Naukowe.

Edkins, Brett. 2016. Donald Trump's Election Delivers Massive Ratings For Cable News. Forbes Online, December 1, 2016.

Eichenwald, Kurt. 2016. How Donald Trump Ditched U.S. Steel Workers in Favor of China. Newsweek Online, October 3, 2016.

Foster, John Bellamy. 2010. The Age of Monopoly-Finance Capital. Monthly Review 61 (9): $1-13$.

Foster, John Bellamy. 2006. Monopoly-Finance Capital. Monthly Review 58 (7): 1-14.

Foster, John Bellamy and Robert W. McChesney. 2012. The Endless Crisis: How MonopolyFinance Capitalism Produces Stagnation and Upheaval from the USA to China. New York: Monthly Review Press.

Franko, Elizabeth. 2006. Democracy at Work? The Lessons of Donald Trump and The Apprentice. In How Real Is Reality TV? Essays on Representation and Truth, ed. David S. Escoffery, 247-258. Jefferson, NC: McFarland \& Company.

Friedersdorf, Conor. 2016. The Radical Anti-Conservatism of Stephen Bannon. The Atlantic Online, August 25, 2016.

Fromm, Erich. 1997. To Have Or To Be? New York: Continuum.

Fromm, Erich. 1936. Sozialpsychologischer Teil. In Studien über Autorität und Familie, 77135. Lüneburg: zu Klampen.

Fuchs, Christian. 2017a. Marx's Capital in the Information Age. Capital \& Class 41, DOI: $10.1177 / 0309816816678573$

Fuchs, Christian. 2017b. Social Media: A Critical Introduction. London: Sage. Second edition.

Fuchs, Christian. 2016a. Capitalism Today: The Austrian Presidential Election and the State of the Right and the Left in Europe. LSE Euro Crisis in the Press-blog: http://blogs.Ise.ac.uk/eurocrisispress/2016/06/16/capitalism-today-the-austrianpresidential-election-and-the-state-of-the-right-and-the-left-in-europe/ 
Fuchs, Christian. 2016b. Critical Theory of Communication: New Readings of Lukács, Adorno, Marcuse, Honneth and Habermas in the Age of the Internet. London: University of Westminster Press.

Fuchs, Christian. 2016c. Racism, Nationalism and Right-Wing Extremism Online: The Austrian Presidential Election 2016 on Facebook. Momentum Quarterly - Zeitschrift für sozialen Fortschritt (Journal for Societal Progress) 5 (3): 172-196.

Fuchs, Christian. 2015. Culture and Economy in the Age of Social Media. New York: Routledge.

Fuchs, Christian. 2008a. Foundations and Two Models of Guaranteed Basic Income. In Perspectives on Work. Perspectives of Social Ethics Volume 1, ed. Otto Neumaier, Gottfried Schweiger and Clemens Sedmak, 235-248. Vienna: LIT.

Fuchs, Christian. 2008b. Internet and Society: Social Theory in the Information Age. New York: Routledge.

Fuchs, Christian. 2004. The Antagonistic Self-Organization of Modern Society. Studies in Political Economy 73: 183-209.

Gambino, Lauren and Alan Yuhas. 2016. Rex Tillerson Named as Donald Trump's Secretary of State. The Guardian Online, December 13, 2016.

Goodwin, Matthew and Oliver Heath. 2016. Brexit Vote Explained: Poverty, Low Skills and Lack of Opportunities. https://www.jrf.org.uk/report/brexit-vote-explained-poverty-lowskills-and-lack-opportunities

Griffin, Drew, David Fitzpatrick and Curt Devine. 2016. The Truth about Hillary Clinton's Wall Street Speeches. CNN Online, April 20, 2016. http://money.cnn.com/2016/04/20/news/economy/hillary-clinton-goldman-sachs/

Griffin, Roger. 1993. The Nature of Fascism. Abingdon: Routledge.

Haberman, Maggie, Julie Hirschfeld Davis and Eric Lipton. 2017. Sons to Run Trump Business via Trust; Ethicists Still See Conflict. New York Times Online, January 11, 2017.

Handros, Libby. 1991. Trump: What's the Deal? Documentary Film. New York: The Orchard.

Harwell, Drew. 2017. Trump Outlines Plan to Shift Assets, Give Up Management of His Company. The Washington Post Online, January 11, 2017.

Hirsch, Joachim, John Kannankulam and Jens Wissel. 2015. Die Staatstheorie des ,westlichen Marxismus'. Gramsci, Althusser, Poulantzas und die so genannte Staatsableitung. In Der Staat der bürgerlichen Gesellschaft, 93-119. Baden-Baden: Nomos. 2nd edition.

Hiltzik, Michael. 2016. Does Andy Puzder Really Want to Replace his Carl's Jr. Workers with Robots? No, but... Los Angeles Times Online, March 30, 2016.

Hobsbawm, Eric and Terence Ranger, eds. 1983. The Invention of Tradition. Cambridge: Cambridge University Press.

Huang, Jon et al. 2016. Election 2016: Exit Polls. New York Times Online, November 8 , 2016. http://www.nytimes.com/interactive/2016/11/08/us/politics/election-exitpolls.html? $r=0$

Huffschmid, Jörg. 2010. Kapitalismuskritik heute. Zeitdiagnosen: Vom staatsmonopolistischen zum finanzmarktgetriebenen Kapitalismus.

Huffschmid, Jörg. 1990. Staatsmonopolistischer Kapitalismus. In Europäische Enzyklopâdoe zu Philosophie und Wissenschaften, Band 2: F-K, ed. Hans Jörg Sandkühler, 758-761. Hamburg: Meiner.

Institut für Marxistische Studien und Forschungen (IMSF). 1981. Der Staat im staatsmonopolistischen Kapitalismus der Bundesrepublik. Staatsdiskussion und Staatstheorie. Frankfurt am Main: Institut für Marxistische Studien und Forschungen (IMSF).

Jessop, Bob. 2016. The State: Past, Present, Future. Cambridge: Polity.

Jessop, Bob. 1990. Sate Theory: Putting the State in its Place. Cambridge: Polity.

Jopson, Murphy and Sevastopolu 2016. New Trump Hire Pledges Tax and Regulation

Shake-Up. Financial Times Online, November 30, 2016.

https://www.ft.com/content/4e3eb306-b6f7-11e6-961e-a1acd97f622d 
Justia. 1991. Diduck v. Kaszycki \& Sons Contractors, Inc., 774 F. Supp. 802 (S.D.N.Y. 1991). U.S. District Court for the Southern District of New York - 774 F. Supp. 802 (S.D.N.Y. 1991), April 30, 1991. http://law.justia.com/cases/federal/districtcourts/FSupp/774/802/1425921/

Kagan, Robert. 2016. This Is How Fascism Comes to America. The Washington Post Online, May 18, 2016.

Kollanyi, Bence, Philip N. Howard and Samuel C. Woolley. 2016. Bots and Automation over Twitter during the Third U.S. Presidential Debate. http://politicalbots.org/wpcontent/uploads/2016/10/Data-Memo-Third-Presidential-Debate.pdf

Kranish, Michael and Marc Fisher. 2016. Trump Revealed: An American Journey of Ambition, Ego, Money and Power. London: Simon \& Schuster.

Kurlantzick, Joshua. 2016. State Capitalism: How the Return of Statism is Transforming the World. Oxford: Oxford University Press.

Laskos, Christos and Euclid Tsakalotos. 2013. Crucible of Resistance: Greece, the Eurozone \& the World Economic Crisis. London: Pluto.

Lazare, Sarah. 2016. Trump's Disastrous Education Pick: A Billionair Heir of Right-Wing Dynasty and Champion of Privatization Effots. Alternet, November 23, 2016.

Lenin, Vladimir I. 1917. The State and Revolution. In Lenin Collected Works, Volume 25, 385-497. Moscow: Progress.

Levine, Daniel S. 2016. Wilbur Ross: 5 Fast Facts You Need to Know. http://heavy.com/news/2016/11/wilbur-ross-jr-donald-trump-cabinet-treasury-net-worthbio-who-is-wl-secretary-wife-commerce/

Marcos, Subcomandante. 2002. Our Word Is Our Weapon: Selected Writings. New York: Seven Stories Press.

Mason, Tim. 1995. Nazism, Fascism and the Working Class. Cambridge: Cambridge University Press.

Matthews, Dylan. 2016. I Asked 5 Fascism Experts Whether Donald Trump Is A Fascist. Here's Whay They Say. Vox Online, May 19, 2016.

McGuigan, Jim. 2008. Apprentices to Cool Capitalism. Social Semiotics 18 (3): 309-319.

Moore, Michael. 2007. Sicko. New York: Dog Eat Dog Films.

National Bureau of Statistics of China. 2016. Statistical Communiqué of the People's Republic of China on the 2015 National Economic and Social Development. http://www.stats.gov.cn/english/PressRelease/201602/t20160229_1324019.html

Neumann, Franz. 2009 [1944]. Behemoth: The Structure and Practice of National Socialism, 1933-1944. Chicago, IL: Ivan R. Dee.

Neumann, Franz. 1957. The Democratic and the Authoritarian State. Glencoe, IL: The Free Press.

Neumann, Franz, Herbert Marcuse and Otto Kirchheimer. 2013. Secret Reports on Nazi Germany. The Frankfurt School and the War Effort. Princeton, NJ: Princeton University Press.

Nunns, Jim, Len Burman, Ben Page, Jeff Rohaly, and Joe Rosenberg. 2016. An Analysis of Donald Trump's Revised Tax Plan. October 18, 2016. Washington, DC: Tax Policy Center.

O’Brien, Timothy L. 2016. Trump's Financial Report? That's Rich. Bloomberg View, May 20, 2016.

Oppenheim, Maya. Rosie O'Donnell hits back at Donald Trump after He Stands By "Fat Pig" Comments. The Independent Online, September 27, 2016.

Özkirimli, Umut. 2010. Theories of Nationalism: A Critical Introduction. Basingstoke: Palgrave Macmillan. Second edition.

Paxton, Robert O. 2016. Is fascism back? Project Syndicate, January 7, 2016.

Paxton, Robert O. 2004. The anatomy of fascism. New York: Knopf.

Pollock, Friedrich. 1975. Stadien des Kapitalismus. Munich: C.H. Beck. 
Pollock, Friedrich. 1941. Is National Socialism a New Order? Studies in Philosophy and Social Science 9 (3): 440-455.

Poulantzas, Nicos. 1980/2000. State, Power, Socialism. London: Verso. New edition.

Pruitt, Scott and Luther Strange. 2016. The Climate-Change Gang. National Review Online, May 17, 2016.

Puzder, Andy. 2014. Minimum Wage, Maximum Politics. The Wall Street Journal Online, October 5, 2014.

Qiu, Jack L. 2016. Goodbye iSlave: A Manifesto for Digital Abolition. Urbana, IL: University of Illinois Press.

Reich, Wilhelm. 1972. The Mass Psychology of Fascism. London: Souvenir Press.

Robbins, Tom. 1999. Deal Sealed in Trump Tower Suit. New York Daily News, March 8, 1999.

Sanders, Bernie. 2016a. Carrier Just Showed Corporations How to Beat Donald Trump. The Washington Post Online, December 1, 2016.

Sanders, Bernie. 2016b. Our Revolution: A Future To Believe In. London: Profile.

Schmitt, Carl. 1932/1996. The Concept of the Political. Chicago, IL: University of Chicago Press

Scott, Eugene. 2016. Donald Trump: Fidel Castro is Dead! CNN Online, November 26, 2016.

Scott, Robert E. 2011. Heading South: U.S.-Mexico Trade and Job Displacement after NAFTA. Washington, DC: Economic Policy Institute.

Shear, Michael D. and Eric Lipton. 2016. Trump Vows Steps to Avoid Appearance of Business Conflicts. New York Times Online, November 30, 2016.

Stelter, Brian. 2016. Debate Breaks Records As Most-Watched in U.S. History. CNN Online, September 27, 2016.

Sum, Ngai-Ling and Bob Jessop. 2013. Towards a Cultural Political Economy. Putting Culture in its Place in Political Economy. Cheltenham: Edward Elgar.

Sundaram, Rangarajan K. 2012. Derivatives in Financial Market Development. Working Paper. London: International Growth Centre.

Todd, Chuck, Sally Bronston and Matt Rivera. 2017. Rep. John Lewis: “I Don't See Trump As A Legitimate President". NBC News Online, January 14, 2017.

Trump, Donald. 2016a. Address on Immigration. Phoenix, Arizona. August 31, 2016. https://www.donaldjtrump.com/press-releases/donald-j.-trump-address-on-immigration

Trump, Donald. 2016b. Full Transcript of an Interview with the New York Times. New York Times Online, November 23, 2016. http://www.nytimes.com/2016/11/23/us/politics/trumpnew-york-times-interview-transcript.html

Trump, Donald. 2016c. Let Me Ask America A Question. Wall Street Journal Online, April 14, 2016.

Trump, Donald. 2016d. Trump to Ohio: I Will Campaign For Every Vote. https://www.donaldjtrump.com/press-releases/trump-to-ohio-i-will-campaign-for-every-vote

Trump, Donald. 2015a. Crippled America: How To Make America Great Again. New York: Threshold Editions

Trump, Donald. 2015b. Donald J. Trump Statement on Preventing Muslim Immigration. https://www.donaldjtrump.com/press-releases/donald-j.-trump-statement-on-preventingmuslim-immigration

Trump, Donald. 2007. Trump 101: The Way to Success. Hoboken, NJ: John Wiley \& Sons

Trump, Donald and Bill Zanker. 2008. Think Big: Make It Happen in Business and Life. New York: Harper.

Tsur, Oren, Katherine Ognyanova and David Lazer. 2016. The Data Behind Trump's Twitter Takeover. Politico Magazine, April 29, 2016. http://www.politico.com/magazine/story/2016/04/donald-trump-2016-twitter-takeover213861

Weisbrot, Mark, Stephan Lefebvre and Joseph Sammut. 2014. Did NAFTA Help Mexico? An Assessment After 20 Years. Washington, DC: Center for Economic and Policy Research. 
Zaru, Deena. 2016. Rosie O'Donnell Responds to Donald Trump Debate Attak. CNN Online, September 27, 2016.

\section{About the Author}

Christian Fuchs is co-editor of tripleC: Communication, Capitalism \& Critique

(http://www.triple-c.at). He is a professor at the University of Westminster and a member of the European Sociological Association's Executive Committee. His research focuses on critical theory, media \& society, the Internet \& society. 